\title{
THE VENUE CLAUSE AND TRANSPORTATION OF LAWSUITS
}

\author{
J. C. Grbson* \\ INTRODUCTION
}

It is not often that venue rules are the source of general dissatisfaction or controversy, or the subject of constant pressure for revision. But the history of venue under the Federal Employers' Liability Act ${ }^{1}$ has been attended with controversy and agitation for change beginning when the ink was hardly dry on the statute and continuing down to the present day.

The history falls into six fairly well defined periods:

(I) From Ig08 to IgIo suits under the Act were governed by the narrow and restricted venue rules of the general federal venue statute requiring a suit against a corporation to be filed in a district in the state of its incorporation, and often depriving the parties of a convenient federal forum.

(2) Between $x 910$ and $x 918$ the broad language of the special venue amendment of xgro to the FELA permitting suit to be brought anywhere defendant may be doing business, coupled with the judicial gloss upon it, gave rise to the opposite kind of abuse-the transportation of causes of action for suit at distant points, with such attendant evils as solicitation of claims, fomentation of litigation, fraud, and perjury.

(3) From IgI8 to 1920 when the carriers were under federal control, the Director General of Railroads restricted venue by administrative order, checking the previous abuses.

(4) Between I920 and I94I after the lapse of the Director General's restrictions of venue, a mixed trend ensued with a revival of the abuses, checked in part by judicial decisions denying the right to maintain a suit under the Act at a distant point where a burden on interstate commerce resulted, or applying the doctrine of forum non conveniens, or enforcing by injunction the equitable principle granting relief from vexatious or oppressive lawsuits.

(5) From I94I to I948 following Baltimore \& Ohio R. R. v. Kepner, and Miles v. Illinois Central $R . R_{.}{ }^{3}$ most of the legal checks upon the transportation of these lawsuits were removed, or clouded in doubt.

* Vice President and General Counsel, The Atchison, Topeka and Santa Fe Railway System.

${ }^{1}$ Aet of April 22, I908; c. I49, \$I, 35 STAT. 65, 45 U. S. C. $\$ 5$ I (1946). The special venue clause was inserted in Section 6 of the Federal Employers' Liability Act by the Act of April 5, 1910. Ch. 143, \$1, 36 STAT. 29I, 45 U. S. C. $\$ 56$ (1946). The present venue clause reads:

"Under this chapter an action may be brought in a district court of the United States, in the district of the residence of the defendant, or in which the cause of action arase, or in which the defendant shall be doing business at the time of commencing such action. The jurișdiction of the courts of the United Smres under this chapter shail be concurrent with that of the courts of the several States."

3 I U. S. 44 (I94I).

3 315 U. S. 698 (1942). 
(6) From 1948 to date, some of the restraints were restored by the forum non conveniens transfer rule of the new Section 1404(a) of the Judicial Code, as interpreted in Ex parte Collett ${ }^{5}$ and Southern Ry. v. Mayfield. ${ }^{6}$

\section{Experience Under the General Federal Venue Statute}

The FELA when passed in 1908 contained no provision governing venue. The subject was therefore left to be governed by the general federal venue statute then in effect, which fixed the venue of a suit brought under a federal statute in the court .in the district in which a defendant corporation was an inhabitant.?

In some of the early cases under the Act the point was raised that the defendant, being an inhabitant only of the state of its incorporation, was suable only there and not in the jurisdiction where the plaintiff resided or where the cause of action arose. Thus in Cound v. Atchison, T. \& S. F. Ry. ${ }^{8}$ the plaintiff, alleging himself to be a resident and citizen of El Paso, Texas, brought suit against a railroad for personal injuries occurring at Raton in the adjoining Territory of New Mexico. The defendant interposed a plea to the jurisdiction, setting forth that the only proper venue was in the district of Kansas, where the defendant was incorporated. The court sustained the plea, holding that while plaintiff was entitled to institute his action in a federal court because it was brought under a federal statute, the only proper venue was in the district of incorporation of the defendant.

If the jurisdiction had been founded only on the fact of diversity of citizenship, then the suit could have been brought in the district of the residence of either the plaintiff or the defendant. Since, however, the Cound suit was primarily based on another ground-a civil right arising under a federal statute-the right to a choice of venue under the diversity clause did not come into play, and the court held that plaintiff was restricted to one place-the district of residence of the defendant. The case was not appealed, apparently because plaintiff preferred to refile his suit in a state court in Texas where no difficulties with respect to venue stood in his way.

The Cound case was decided in November, rgog. In the following month a

62 STAT. 937 (I948), 28 U. S. C. 51404 (a) (Supp. I952).

337 U. S. 55 (I949).

340 U. S. I (1950).

7 The governing statute was the Act of March 3, 1887, as amended by the Act of August 13, 1888 , c. 866,25 STAT. 433 , the pertinent parts of which read as follows:

"That the circuit courts of the United States shall have original cognizance, concurrent with the courts of the several States, of all suits of a civil nature, at common law or in equity, where the matter in dispute exceeds, exclusive of interest and costs, the sum or value of two thousand dollars, and arising under the Constitution or laws of the United States, or treaties made, or which shall be made, under their authority, or in which controversy the United States are plaintiffs or petitioners, or in which therc shall be a controversy between citizens of different States, in which the matter in dispute execeds, exclusive of interest and costs, the sum or value aforesaid. . . . But no person shall be arrested in one district for trial in another in any civil action before a circuit or district court; and no civil stit shall be brought before either of said courts against any person by any original process or proceeding in any other district than that whereof he is an inhabitant, but where the jurisdiction is founded only on the fact that the action is between citizens of different States, suit shall be brought only in the district of the residence of either the plaintiff or the defendant. . . ' (italics supplied.)

${ }^{8}{ }_{173}$ Fed. 527 (C. C. W. D. Texas, 1909).

- The opinion in the case concludes with the observation:

"The plaintiff did not except to the ruling, preferring to institute his suit in the state court." Id. at 530 . 
similar conclusion was reached by a federal circuit court in Ohio in Smith $v$. Detroit $\mathcal{E}$ T.S.L.R. R. ${ }^{10}$ In this case the action was brought in Ohio against a Michigan corporation. The plaintiff was a citizen of the district and alleged that he had been injured in the course of his employment by defendant railroad. Where the accident took place does not appear. A motion to dismiss was sustained because the suit properly could have been brought only in the district of Michigan, of which the defendant was an inhabitant, the court citing and relying on the Cound case.

A little later the Supreme Court placed the same interpretation upon the diversity clause, declaring it inapplicable to a suit brought against a corporation under the Interstate Commerce Act. ${ }^{11}$

The law as thus interpreted required a plaintiff, if injured in a jurisdiction outside of the state of incorporation of the employing railroad, and if desirous of bringing suit in a federal court, to transport his case to the state of incorporation of defendant railroad which might be many hundreds of miles away from his own residence or from the place where the accident occurred. This was undoubtedly a considerable inconvenience, tempered only by the circumstance intimated by the court in the Cound case that plaintiff could bring suit in a state court more conveniently situated. But the right to sue in a state court had been somewhat clouded by the decision of the Supreme Court of Connecticut during the summer of 1909 in Hoxie v. New York, N.H.\& H.R.R., ${ }^{12}$ declining jurisdiction under the FELA upon the ground, among others, that Congress had not expressly provided that jurisdiction should be assumed by state courts. If this view were correct, and if the cause of action under the statute were not cognizable in a state court, then the injured plaintiff would have the right to maintain his suit only in a federal court in the district of incorporation of the defendant railroad, which in many cases would work substantial hardship.

The decision in the Hoxie case was clearly wrong. Since there was nothing in the Act which indicated an intention on the part of Congress to confine suits thereunder to the federal courts, an express grant of concurrent jurisdiction to state courts was unnecessary, in view of the supremacy clause of the Federal Constitution and the general jurisdictional act. ${ }^{13}$

${ }^{10} \times 75$ Fed. 506 (C. C. N. D. Ohio, I909).

${ }^{21}$ Macon Grocery Co. v. Atlantic Coast Iine R. R., 215 U. S. 501 (1910).

1282 Conn. 352, 73 Atl. 754 (I909).

${ }^{13}$ The Committees on the Judiciary of the House and Senate so declared and demonstrated at length in their respective reports on the amendment of I9IO. House REp. No. 513, 6xst Cong., 2d Sess. 7-8 (Feb. 22, 1910); SEN. Rep. No. 432, 6rist Cong., 2d Sess. 5 (March 22, 1910). The Hoxie case was not appealed to the Supreme Court of the United States but the same question was raised in the Second Employers' Liability Cases, 223 U. S. I, 55-59 (x9II), and the Court held that the Act may be enforced as of right in the courts of a state when their jurisdiction as prescribed by local law is adequate to the occasion. The Court said (at p. 56):

"We are quite unable to assent to the view that the enforcement of the rights which the congressional act creates was originally intended to be restricted to the Federal courts. The act concains nothing which is suggestive of such a restriction, and in this situation the intention of Congress was reflected by the provision in the general jurisdictional act, "That the circuit courts of the United States shall have original cognizance, concurrent with the courts of the several States, of all suits of a civil nature, at common law or in equity, where the matter in dispute exceeds, exclusive of interest and costs, the sum or value of two thousand dollars, and arising under the Constitution or laws of the United States.' August 13, I888, 25 STAT. 433, c. 866, $\$$ I. Robb v. Connolly, II U U. S. 624, 637; United States v. Barnes, 222 U. S. 513." 
For the time being, nevertheless, the Hoxie case cast a cloud over the right of an injured plaintiff to proceed under the Act in a state court just as the Cound and $S$ mith cases seemed to preclude resort in many cases to a reasonably convenient federal forum.

\section{Spectal Venue Amendment of}

A movement was begun in Congress to remedy the restrictions on venue disclosed by the decisions in the Cound and Smith cases and to overrule the patently erroneous holding with respect to jurisdiction of state courts in the Hoxie case and, as a result, the special venue amendment of rgro was added to the FELA. The proper interpretation and effect of this clause and the intent of Congress in its enactment have been the subject of controversy in many cases continuing to the present day. As time wore on the words of the clause itself became in many respects of less importance than the gloss placed upon them by the courts in a sizable body of decisions whose influence has been felt to the present day. "Since the words selected by Congress for $\$ 6$ [the venue clause]," Chief Justice Vinson has said, "denote nothing, one way or the other respecting forum non conveniens, there was no occasion to repeal that section, expressly or impliedly; Congress chose to remove its judicial gloss via another statute."14 Because much of the gloss is still with us, and because it cannot be fully understood or adequately evaluated without some knowledge of the legislative history of the clause, an examination of its progress through Congress is of more than usual importance.

The defect in venue which had become apparent in the early cases could have been cured in either of two ways. The general federal venue statute which was governing under the Act of 1908 could have been changed so as to permit suits brought under a federal statute to be brought in the same venue as suits brought under the diversity of citizenship clause; that is, in the district of the residence of either the plaintiff or the defendant. Again the defect could have been remedied by amending the FELA itself to include a separate venue clause. The second alternative was the one that found favor in Congress.

A bill, drafted by the Attorney General, ${ }^{15}$ was introduced in the House to accomplish this objective as well as to provide for the survival of certain causes of action arising under the statute. ${ }^{16}$

The bill provided for four places of venue-(I) the district of residence of the

14 Ex parte Collett, 337 U. S. 55, at 61. The other statute was Section I404(a) of the Judicial Code, 28 U. S. C., enacted in 1948.

${ }^{25}$ Liability of Common Carriers to Employees, Hearings before the Subcommittee of the Senate Committee on the Judiciary on H. R. 17263 , 6rst Cong., 2 d Sess. 8 (1910).

${ }^{10} \mathrm{H}$. R. I7263, 6rst Cong. 2d Sess. (19ro). This bill proposed to amend Section 6 of the Act, which as originally passed had simply provided for a two year limitation period, by inserting a new paragraph dealing with venue and jurisdiction of federal and state courts. As originally introduced this paragraph read:

"Under this act an action may be brought in a circuit court of the United States in the district of the residence of either the plaintiff or the defendant, or in which the cause of action arose, or in which the defendant shall be found at the time of commencing such action. This act shall not be construed as excluding the exercise of a concurrent jurisdiction of cases arising under the act by the courts of the several states." 45 Cong. REc. 2253 (I9ro). 
defendant; (2) the district of residence of the plaintiff; (3) the district where the cause of action arose; and (4) the district in which the defendant is found at the commencement of the action. The first category was the one named in the general venue statute of the day; the other three were new. For all practical purposes, the fourth place of venue-the district where the defendant might be found-was broad enough to embrace the other three, for it allowed suit practically anywhere the defendant might be served in keeping with due process of law. The bill also expressly stated that it should not be construed as excluding the exercise of a concurrent jurisdiction by the courts of the several states.

The bill was referred to the Judiciary Committee and was reported out favorably without a hearing. In its report the committee proposed an amendment to the bill striking out the last sentence of the clause, which disclaimed an intention to exclude state courts from the exercise of jurisdiction under the Act, and substituting a provision, which while still stopping short of an express grant of jurisdiction to state courts, recognized it as already present: "The jurisdiction of the courts of the United States under this Act shall be concurrent with the courts of the several states."17

The committee stressed the element of convenience of venue, saying that; the amendment enumerating places of venue was necessary in order to avoid great inconvenience to suitors and to relieve an injured plaintiff from the burden of instituting suit in a federal court in the state of incorporation of the defendant. ${ }^{18}$

${ }^{17}$ House Rep. No. 513, 6rst Cong., 2d Sess. Feb. 22, x9ro, by Representative Sterling for the Committee on the Judiciary, p. $x$. The Committee at p. 7 explained the purpose of this amendment:

"It is proposed to further amend the act by making the jurisdiction of the courts of the United States 'concurrent with the courts of the several States.'

"This is proposed in order that there shall be no excuse for courts of the States to follow in the error of the Supreme court of errors of Connecticut in the case of Hoxie v. N. Y. N. H. \& H. R. R. (73 Atl. Rep. 754), in which case the court declined jurisdiction upon the ground, inter alia, that Congress did not intend that jurisdiction of cases arising under the act should be assumed by state courts.

"It is clear under the decisions of the Supreme Court of the United States, that this conclusion of the Connecticut court is erroneous. And the reasons recited by the Connecticut court lead to an opposite conclusion from that which the opinion declares upon the subject. But no harm can come, and much injustice and wrong to suitors may be prevented by an express declaration that there is no intent on the part of Congress to confine remedial actions brought under the employers' liability act to the courts of the United States."

As already noted, the committee went on to demonstrate at length the mistake of the Connecticut court. Representative Sterling said on the floor that without this clause the federal courts and the state courts already had concurrent jurisdiction and the express statement was being inserted to avoid the possibility of a repetition of the error made in the Hoxie case. 45 Cong. REc. 2253 (1910).

${ }^{18}$ The committe report, submitted by Representative Sterling of Illinois, the author of the bill, described the hardship and injustice of requiring suit to be brought at a distant place:

"This amendment is necessary in order to avoid great inconvenience to suitors and to make it unnecessary for an injured plaintiff to proceed only in the jurisdiction in which the defendant corporation is an 'inhabitant.'

"This is held by the courts to be the jurisdiction in which the charter of the defendant corporation was issued. This may be at a place in a distant state from the home of the plaintiff, and may be a thousand miles or more from the place where the injury was occasioned.

"The extreme difficulty, if not impossibility, of a poor man who is injured while in railroad employ securing the attendance of the necessary witnesses at such a distant point makes the remedy given by the law of little avail under such circumstances.

"It seems clear from these decisions that a suit in a federal court under this law, where jurisdiction is founded on the fact that the case involves a federal staute, must be brought in the district of which 
When the bill was considered on the floor of the House its leading proponent pressed two points: first, the hardship of forcing an injured employee to carry his witnesses to a court located in a distant state, ${ }^{10}$ and second, the reasonableness of putting into effect in the federal courts "the same rule in reference to the place of bringing suit that is provided in practically all of the states of the Union."20 At the same time he specifically disclaimed any intention of enlarging the jurisdiction of the federal courts or curtailing that of the state courts. ${ }^{21}$

A suggestion in the course of debate in the House that the greatly enlarged venue might impose hardship upon a defendant by compelling him to take his witnesses to a distant place was countered with the assertion that under the proposed measure suit would be brought at a place convenient to both the plaintiff and the defendant since the plaintiff would be likely to bring suit where it is most convenient to himwhere the witnesses reside or the place of the injury. ${ }^{22}$

After passage by the House but before Senate consideration of the bill, President Taft in a special message to Congress on another subject on January 7 , 1910, recom-

the defendant is an inhabitant.

"No argument is necessary to convince that this is a grave injustice to the plaintiff.

"Such an embarrassing situation ought not to be permitted to exist where any plaintiff is procceding in a federal court on a right based on the law of the United States.

"But to permit it to be a practical barrier to the maintenance of an action for death or personal injuries of employees who may be presumed to be unable to meet the expense of presenting their case in a jurisdiction far from their homes would be an injustice too grave and serious to be longer permitted to exist." House REP. No. 513, 6xst Cong., 2d Sess. 6 et seq. submitted Feb. 22, 1910, by Representative Sterling for the Committee on the Judiciary.

1945 Cong. Rec. 2255-60 (I910).

${ }^{20} \mathrm{Mr}$. Sterling said on the floor of the House:

"I think that the amendment in this bill simply provides the same rule in reference to the place of bringing suit that is provided in practically all of the States of the Union. Now, they can always, in the state courts, bring suit, as a rule, wherever the defendant can be found, and this simply gives the plaintiff the right to bring suit in a federal court where the defendant can be found." Id. at 2257.

${ }^{21}$ The following colloquy during the debate of Feb. 23, x9ro, illustrates this point:

'Mr. Clark of Missouri. Does this bill in any way enlarge the jurisdiction of the United States courts or curtail the jurisdiction of the state courts?

"Mr. Sterling. It does not. It makes it much more convenient for the plaintiff to bring his suit by providing that he may sue in his own district or the defendant's district or where the injury occurred or where the defendant may be found. As the law is now, a suit can only be brought in the district where the defendant is domiciled." Id. at 2255.

${ }^{22}$ In the debate in the House on Feb. 23, xgro, the following discussion took place:

"Mr. Burke of Pennsylvania. What is the necessity of giving the United States court jurisdiction in a district in which both the plaintiff and the defendant reside, and in which the plaintiff has his remedy in the courts of the State?

"Mr. Moon of Pennsylvania. Suppose a case where an accident occurred from too to 500 miles away from the home of the plaintiff, and all the witnesses resided there. It would be a great hardship upon the plaintiff not to allow him the right to bring the action where the accident occurred and where the witnesses were present.

"Mr. Burke of Pennsylvania. And that throws light upon the very business that the gentleman has been familiar with of bringing actions, and would impose as much hardship by bringing actions in remote places under such a change of the law, and thus compel the defendant to take his witnesses a very great distance at his very great disadvantage.

"Mr. Sterling. The plaintiff is likely to bring suit where it is most convenient to him; that is, where the witnesses reside or the place of the injury. That would also be most convenient to the defendant. An injured employee ought not to be required to carry his witnesses a long distance." Id. at 2257 . 
mended that it be enacted into law, ${ }^{23}$ saying that the right to bring suit under the Act should be as easy of enforcement as the right of a private person not in the company's employ to sue on an ordinary claim.

When the bill as passed by the House was sent to the Senate it was referred to the Committee on the Judiciary which in turn referred it to a subcommittee of which Senator Borah of Idaho was Chairman. ${ }^{24}$ At a hearing before the subcommittee four witnesses appeared, two of them, Mr. Henry J. Taylor, Jr. and Mr. Charles J. Faulkner, representing the railroad companies, ${ }^{25}$ and two others, Mr. Edward A. Moseley, and Mr. Philip J. Doherty, apparently speaking for the employees. ${ }^{26}$ All four of the witnesses stated that the existing venue rule, being unduly narrow and restricted, was productive of inconvenience and hardship and should be liberalized. All four supported the pending bill, although the railroad witnesses, apprehensive that it went to the opposite extreme, asked for some modifications.

Both Mr. Taylor and Mr. Faulkner stated that the requirement of bringing suit at the place of incorporation of the railroad imposed a hardship not only on plaintiffs, but on defendants as well who had suffered inconvenience in bringing witnesses to a trial at such a location. ${ }^{27}$ They favored allowing suit at the residence of the

${ }^{23}$ President Taft, after urging a statutory amendment giving the Interstate Commerce Commission authority to prescribe standards of construction for sill steps, ladders, hand brakes, and other matters, also recommended the enactment of $\mathrm{H}$. R. 17263, saying:

"The question has arisen in the operation of the interstate commerce employers' liability act as to whether suit can be brought against the employer company in any place other than that of its home office. The right to bring the suit under this act should be as easy of enforcement as the right of a private person not in the company's employ to sue on an ordinary claim, and process in such suit should be sufficiently served if upon the station agent of the company upon whom service is authorized to be made to bind the company in ordinary actions arising under state laws. Bills for both the foregoing purposes have been considered by the House of Representatives and have been passed, and are now before the Interstate Commerce Committee of the Senate. I earnestly urge that they be enacted into law." SEN. Rep. No. 432, supra, at 3-4; 45 Cong. Res. 38 I (I910).

34 The other members of the subcommittee were Senator Sutherland of Utah, later a member of the Supreme Court of the United States, and Senator Paynter of Kentucky who had been Chief Justice of that state.

${ }^{25} \mathrm{Mr}$. Taylor was Solicitor of the Chesapeake and Ohio Railroad Company, and Mr. Faulkner was an attorney and former Senator from West Virginia.

${ }^{20} \mathrm{Mr}$. Moscley then and for many years was Secretary of the Interstate Commerce Commission, and Mr. Doherty was one of its attorneys. They disclaimed speaking for the Commission. Mr. Moseley at one place stated that they were representing the public, but at another place he stated that "There is no desire on the part of those who represent the men to ask anything unfair." No one else appeared for the men. Senate Hearings, stupra note 15 , at 3,9 , 10.

${ }^{27}$ "Mr. Taylor. On page 6 you will find that the evil which they were attempting to correct was the great hardship upon a plaintiff to be required to bring his suit in the district of the residence of the defendant, necessitating his going sometimes several thousand miles to reach the home office of a large road extending through many States. I happen to represent a road, and have done so for the last twenty-five years, which extends through three States and into a fourth State, and it is a great hardship on the defendant to have to do that same thing, because suits are now brought at the home office and the defendant has to bring its witnesses. So it was a very proper amendment of the law to propose." ld. at 3-4.

"Mr. Faulkner. Mr. Chairman, there appears to be very little difference between us. It is admitted that this act should only go to the extent of providing what is best for the parties to be affected by its provisions, and that this committee must, of course, determine that question in acting upon the proposed amendments. It is not simply a question what is to the interest of the plaintiff in such an action or what is best for the defendant. The question is, What is an equitable and just rule in the interest of both parties? That is what the committee will seek to determine, and upon that principle, regardless of 
defendant or the place where the cause of action arose, saying that it would satisfy the convenience of both parties and witnesses and be fair and workable in its operation. Most suits, they were convinced, would be brought where the cause of action arose. ${ }^{28}$ To allow venue at the residence of the plaintiff or at any place where defendant might be found, however, they considered unnecessary and unwise, going far beyond the evil intended to be remedied. It would work a hardship on the defendant to permit suit anywhere the plaintiff might reside as it might be far away from the place where the cause of action arose. ${ }^{20}$ They were especially apprehensive regarding possible abuse of the clause authorizing suit at any place where the defendant might be found. They feared that it might be construed to

any other question.

"Let us see how the law stands to-day. As it stands to-day, without amendment, you can not bring a suit under the employers' liability act except at the residence of the defendant. . . .

"That is a hardship to both parties, and the law ought to be amended." Id. at 9, 10 .

28 'Mr. Taylor. . . I I personally would be perfectly willing to strike out the words 'the residence of the defendant' but I see no use in the provision. That scems to be the general law now, and there is no use in interfering with the general law. It may be that occasionally it is more convenient to the plaintif, as well as to the defendant, to bring the suit in the residence of the defendant.

"What ought to be, and what is fair to both sides, and what can hurt no one, is that the suit shall be brought where the cause of action arose. There the whole matter can be litigated between the parties with all of their witnesses within reasonable distance, and nobody can be hurt by such a provision as that." Id. at 4 .

"On the whole it seems to me that the fairest jurisdiction is that where the cause of action arose, and that that ought to be the limitation as to the jurisdiction under this act, with the exception, possibly, that the suit shall be brought also in the residence of the defendant, because of the fact that that is the law now, and there is no necessity for making any change specially in that respect. That would confine the jurisdiction to the residence of the defendant or where the cause of action arose, and as between those two, nine hundred and ninety-nine out of every thousand cases would be brought where the cause of action arose, because that is the more convenient to both partics." Id. at 5 .

"Mr. Faulkner. . . The question is, What is the object of this law? Its purpose is to give to the employee of a railroad who is injured a remedy against the defendant for the purpose of giving him compensation for the injury incurred in the operation of the road. The probabilities are, and the natural result of such a law is, that every suit will be brought by the plaintiff himself where the cause of action arose, or at the place of the defendant's residence. ..." Id. at ro.

${ }^{20} \mathrm{Mr}$. Taylor objected to these two places of venue, saying:

"But if you will examine the amendment you will find that it has gone far beyond the cvil that was intended to be corrected. You will see that it authorizes that an action may be brought in a circuit court of the United States, in the district of the residence of either the plaintff or the defendant, or in which the cause of action arose, or in which the defendant shall be found at the time of commencing such action.'

"You will see at once that that is likely to impose a great deal more hardship than the original act. For example, a person may be injured in the eastern district of Virginia, but his residence may be in Pennsylvania. He can then bring his suit where he resides, provided, of course, that he can get scrvice upon the defendant in the district in which the suit is brought. It is surely very inequitable that the cause of action which has arisen-we will say in the eastern district of Virginia-should be litigated between the parties in some districe in Pennsylvania, if perchance the defendant happens to be doing business and has such an agent doing business there as would enable proper service to be made." Id. at 4 .

Mr. Faulkner's testimony was to the same effect:

"We maintain that there ought to be some equitable, just limitation as to the district in which the suit shall be brought. We believe that nine out of ten cases would be tried near the line of the road where the cause of action accrued, because it would be in the interest of the plaintiff to do so. But we must guard against the possibility of such wide authority being abused. For that reason we request the committe to strike out the provision allowing suit to be brought at the residence of the plaintiff." Id. at II. 
allow suit in a distant part of the country if an officer of the corporation could be found and served there, perhaps while traveling or perhaps while soliciting traffic. ${ }^{30}$

Mr. Faulkner illustrated the possibilities of the abuse of venue by citing the possibility of the appointment in a remote state of an administrator of the estate of a deceased employee to bring suit for damages on account of his death. ${ }^{31}$ Mr. Faulkner indeed was so much concerned over the danger of the clause providing for venue wherever the defendant might be found that he seemed at one time to suggest that it would be appropriate to provide for venue wherever defendant might be doing business. $^{32}$

The proponents of the bill in its original form, Mr. Moseley and Mr. Doherty, although willing to provide venue at the place of residence of the defendant or where the cause of action arose, argued that it should not be entirely so confined. Mr. Doherty made the quite valid point that an injury might happen far distant

30 "Mr. Faulkner. Then whoever he represents he agrees that the employee will not have the ability to bring witnesses a lang distance, and therefore it will be to the interest of the plaintiff to bring his suit where the cause of action accrued, where the witnesses to prove his case reside, and the burden of the expense of litigation will be lessened to that extent. I do not mean to say, however, that where the cause of action arose should be the only district in which he should have the right to sue.

"But take this case. Here is a man injured in the State of West Virginia. He leaves the service of the road. He goes to reside in Idaho. He has two years within which to bring his suit. Is it right or just that he shall, any time within the two years, be allowed to bring suit wherever the defendant can be 'found,' as such language applying to service on corporations has been interpreted by the courts and make the defendant transport his witnesses to a distant point, it may be a thousand miles from the place of injury to the employee?" Id. at ro.

"Why was the word 'found" put in this bill? $\dot{\text { It }}$ is found in the first judiciary act, passed, we must admit, when we knew little of service upon corporations. Under that statute the decisions held that a man passing through a State could have a process served upon him, because the act used the term 'found.' It was intended to apply to individuals at that time, and although process might have been brought within the term, it is of doubtful propriety in such an act, and will lead to litigation in its application to such actions.

"Follow the example of the statutes of all the States on corporations. Such statutes provide that process shall be served upon a corporaion where it is 'doing business.' It was the Pennsylvania statute that used the language discussed in the case of Green v. The Chicago, Burlington and Quincy Railroad (decided in 205 U. S. 530). Most if not all the state statutes, under the circumstances of the use in this bill of the term 'found,' use the language "doing business." "Id. at II, I2.

31 "Mr. Faulkner. That would be the case if the injured party goes to some other part of the country than where the accident occurred, and within two years should bring a suit at his 'residence' or where 'found,' upon securing a technical service on the defendant.

"We say that is not equitable; that it is not just. The injured party moves away from the place of the accident. Unfortunately the injury may result in his death. An administrator qualifies. He may qualify in San Francisco, the injury having occurred in Pennsylvania, and secure a technical service of process upon some one in San Francisco. Is it just that suit be brought by the administrator who has qualified in that city because it was the residence of the deceased, or because he owned property there? If the plaintiff can get service of process either at residence of plaintiff or where found, the jurisdiction is given under this bill. The administrator's residence would be the plaintiff's residence within the meaning of this bill in a suit by the administrator.

"We maintain that there ought to be some equitable, just limitation as to the district in which the suit shall be brought." Id. at ro, II.

${ }^{32} \mathrm{Mr}$. Faulkner. If you give the plaintift the right to sue the defendant where the defendant resides or where the cause of action accrues, and should you go further and give him the right to sue where the defendant is transacting his business, certainly you have enlarged his remedy as far as equity and justice require.

"You have then covered almost every conceivable case that the practical demands of such an act require." Id. at Ix. 
from the place of the residences of the plaintiff and the witnesses, which would impose a burden if they were compelled to resort to a court at the place of the accident. $\mathrm{He}$ cited as an example an instance where a train service employee living in one state crosses one or more state borders in the course of his daily duties." "The purpose of the amendment of the Act," said Mr. Doherty, "is to afford an opportunity to the plaintiff to make selection of the most convenient jurisdiction to get his witnesses."34 He suggested that if there were any conflict between convenience of the plaintiff and convenience of the defendant it should be resolved in favor of the plaintiff who ordinarily is less able to provide transportation to a distant point of trial. ${ }^{35} \mathrm{He}$ stressed the vital importance of providing a forum where the witnesses to an accident could conveniently be brought into court to give their oral testimony instead of being forced to rely upon the poor substitute of evidence by deposition. ${ }^{36}$ Mr. Doherty scouted the likelihood of a plaintiff going away from home to shop for a more favorable jurisdiction because he said the passage of the FELA, by establishing uniform principles applicable throughout the country, had removed the previous temptation born of conflicting rules of liability in the several states to transport a case for suit out of a jurisdiction where it would have its normal situs. ${ }^{37}$

Mr. Moseley sought to impress upon the committee that the injustice of the limitation of venue to the district of incorporation of defendant was an admitted injustice, conceded by all to have arisen from an oversight. He disclaimed asking for anything unfair. "There is no desire on the part of those who represent the men to ask anything unfair."38 Mr. Moseley thought that venue in the district of

${ }^{33}$ "Mr. Doherty. Mr. Chairman, to carry out the purpose of this bill it would seem to be objectionable to limit the jurisdiction to the court of the place where the cause of action arose. The local headquarters of a company may be such that men go out on the trains for runs of 500 or 1,000 miles, and if an injury happens at an extreme point from the place where the witnesses live and are quartered generally, there would be a great expense on the part of a plaintif, a railroad cmployce, to bring his witnesses to the other jurisdiction for the purpose of trial. If the place where the injury happened was over the border of a State, then the place of trial in that jurisdiction might be hundreds of miles away, and the expense of getting a dozen witnesses would be a barrier to litigating the casc." Id. at 7.

si $I d$. at 7 .

35 "Mr Doherty. . . There can be very little trouble to the defendant, because the company furnishes transportation to its witnesses, and wherever the case is litigated the defendant has the opportunity to take its witnesses, and is abundantly able to do that.

"On one side we have a plaintiff without ability to provide for transportation and on the other we have a party who is able to provide for transportation." Id. at 7 .

so "Mr. Doherty. . . . The matter of the ability to get witncsses to a particular point is of vital importance in cases of this kind, because unless the plaintiff can get the personal attendance of his witnesses he is at a disadvantage in a jury trial. To be sure the witnesses can be heard by deposition, but unless the witnesses personally appear the plaintiff is at very great prejudice in the presentation of the case to the jury, whereas the defendant is able to present its witnesses in person to the jury and they make an impression upon the questions at issue." Id. at 7.

37 "Mr. Doherty. . . The temptations to take a defendant out of a particular jurisdiction which existed before the passage of the law of 1908 , do not exist under that law. For instance, in the conflicting rules of personal liability existing in various States it may be of some advantage to a plaintiff to select a particular jurisdiction in which the laws are favorable or in which the administration of the laws is favorable and there get service. The application of this federal law is uniform throughout the United States and a defendant is not prejudiced by the plaintiff's selection of a particular jurisdiction." $1 d$. at 8 .

38 'Mr. Moseley. . . . This limitation of cases arising under the employers' liability act to the jurisdiction of the district in which the defendant is an inhabitant, is an injustice which arose apparently from some inadvertence and ought to be remedied. It is to correct this inadvertence this 
the residence of either the plaintiff or the defendant would have been ample, although he also agreed with Mr. Taylor on the advisability of permitting suit where the cause of action arose. ${ }^{39}$ What he really wanted for injured plaintiffs, and widows and orphans, he made clear, was a choice of venue-a reasonable choiceone that would insure suit in the vicinity where the parties reside and are known. ${ }^{40}$

Mr. Doherty adverted to President Taft's statement of the goal to be achieved by amendment as one of making a suit under the act as easy to bring as a suit of a private person not in the company's employ on an ordinary claim. Senator Borah, Chairman of the subcommittee, remarked that that seemed to be the point at which all parties desired to arrive, the only question being what language should be used to arrive there. ${ }^{41}$

amendment is proposed. There is no desire on the part of those who represent the men to ask anything unfair.

"Mr. Moseley. . . . The necessity for this amendment arises from an oversight conceded by all. Where a federal law applies you can only bring an action in the district where the defendant is an inhabitant. This may be a thousand miles from plaintiff's home. This is an injustice and is admitted to be so, even by the representatives of the railroads." Id. at 9 .

39 "Mr. Moseley. ... The amendment in question was the result of a decision of Judge Maxey in the case of George C. Cound v. The Atchison, Topeka and Santa Fe Railway Company. This was a proceeding under the act of 1908 . Were it not for the fact that the case involved the interpretation of a United States law, jurisdiction in Texas would have been ample. Under the judiciary act the suit could be brought in the district of the residence of either the plaintiff or the defendant.

"Mr. Taylor. May I ask you a question?

"Mr. Moseley. Yes.

"Mr Taylor. What, then, is the objection to making the jurisdiction where the cause of action arose? It seems that your argument leads to that point.

"Mr. Moseley. It is advisable to permit suit where the cause of action arose. But plaintiffs ought not to be limited to such jurisdiction. They should be permitted to bring suit as though a United States law was not involved and have the same choice of jurisdiction which is open to parties generally." Id. at 8,9 .

The choice mentioned was a choice available under the diversity clause between the district of residence of either the plaintiff or the defendant.

10 "Mr. Moseley. We have got to bear in mind that there will be a great many of these cases. It may not be the injured party; he has gone to his long home. It is the widow; it is the orphan. They should be given a reasonably broad choice of jurisdiction. If I were their attorney I should prefer to have some choice of ground on which I would enter this legal contest, because I would have the influence of my vicinity. The jurisdiction of the home of the dependent widow and the children is above all others to be preferred. This is fair to both parties. The reputation of the parties is well known to all there. They know about the people and about the facts." Id. at r3. $_{3}$

"1 "Mr. Doherty. . . . As to the clause "or in which the defendant shall be found at the time of commencing such action,' permit me to suggest that that is the language in which the amendment was prepared at the Attorney General's office. The terms used are frequent in federal statutes and have often been interpreted by courts. This amendment had the approval of the President in his message of January 7, 19ro.

"The Chairman. I remember the message.

"Mr. Doherty. The President said: The right to bring the suit under this act should be as easy of enforcement as the right of a private person not in the company's employ to sue on an ordinary claim, and process in such suit should be sufficiently served, if upon the station agent of the company upon whom service is authorized to be made, to bind the company in ordinary actions arising under state laws.'

"The Chairman. That seems to be the point to which all parties desire to arrive, and the only question would seem to be whether this language covers that proposition.

"Mr. Doherty. If the language used can be improved upon, there will be no objection it it." Id at 8. 
Senator Borah reported the bill out favorably for the Senate Judiciary Committee. The report made two amendments to the bill in the form that it passed the House. The first one struck out the provision for venue in the district of residence of the plaintiff, and the second modified the provision for suit where the defendant may be found by changing it to the district where the defendant may be doing business. ${ }^{42}$

Both changes, it is clear from a review of the testimony before the subcommittee, were made in response to the pleas of the railroads for avoiding an excessive and unnecessary liberalization of venue, opening the way for the very type of abuse at which the amendment was aimed-the transportation of causes of action for suit at distant points. Just as evidently they were made in light of the disclaimer by the other side of any intention to seek an unfair advantage or anything more than a reasonable choice of venue, permitting suit in the vicinity where the plaintiff and the witnesses reside or where the accident happened. In short, the revised bill was couched in language intended to reach, in Senator Borah's words, "the point to which all parties desire to arrive."

The report of the Senate Committee reiterated what had been said by the House Committee about the primary purpose of the venue amendment-the avoidance of inconvenience and hardship to suitors, especially the plaintiff, by requiring suit to be brought at a distant point. ${ }^{43}$

There was less debate in the Senate than in the House on the venue portion of the bill. Senator Borah led off with a brief description of the bill, stressing the inconvenience and hardship of requiring the plaintiff to travel a long distance to the district of incorporation of the defendant. The bill, he said, would remedy this by enabling the plaintiff to bring his action not only at the residence of the defendant but also where the cause of action arose or where the defendant might be doing business, giving the plaintiff his choice. ${ }^{44}$

The question was raised in the ensuing debate whether the law should be left so as to permit the removal to a federal court of a case originally brought under the Act in a state court. Two amendments were proposed to prevent such removal. The first amendment, by Senator Dixon, would have reached the objective indirectly by making a railroad corporation a citizen of every state where it had trackage. ${ }^{45}$ The second amendment, proposed by Senator Paynter and subsequently

SEN. REP. No. 432, 6Ist Cong., 2d Sess. I (Igro).

${ }^{4}$ Id. at 3,4 .

"Mr. Borah. Mr. President, I wish to discuss very brielly the bill. ... The objection which has been made to the existing law, and this objection arises by reason of the decision of some of the courts, is that the plaintiff may sometimes be compelled to go a great distance in order to have his cause of action against the defendant by reason of the fact that now the action must be brought in certain instances in the district in which the defendant is an inhabitant. In other words, the corporation bcing an inhabitant of the State which creates it, it might follow that the plaintiff would have to travcl a long distance in order, under certain conditions, to bring his action against the defendant and come within the terms of the law. So, if this bill should be passed the law will be remedied in that respect, in enabling the plaintiff to bring his action where the cause of action arose or where the defendant may be doing business. The bill enables the plaintiff to find the corporation at any point or place or State where it is actually carrying on business, and there lodge his action, if he chooses to do so." 45 Cong. Rec. 4034 (rgro).

45 Cong. REC. 4092 (1910). 
adopted, provided more directly that "no case arising under this act and brought in any state court of competent jurisdiction shall be removed to any court of the United States." $"$ 6

The purpose of both amendments was the same-to further the general objective of the bill to insure that cases arising under the Act should be litigated locally where they arise and not at some distant point. ${ }^{47}$

Passed by the Senate, the bill went back to the House which concurred in the Senate amendments. ${ }^{48}$ President Taft affixed his signature, and the bill became law April 5, Igro, and its provisions have continued substantially unchanged to the present day. ${ }^{49}$

The amendment to Section 6 of the FELA dealt with three subjects: (r) venue in federal courts; (2) jurisdiction in federal and somewhat indirectly in state courts; and (3) the removal of cases from state to federal courts-which was banned. The provision for removal is pertinent here only as an indication of congressional intention in enacting Section 6 to further the trial of cases close to the place where they arise. The provision with respect to jurisdiction was recognized as not strictly necessary, having been inserted only out of an abundance of caution to prevent a repetition of the error of the Hoxie case. It did not and was not intended to confer jurisdiction on state courts in FELA cases but merely to recognize that this jurisdiction already existed. The really important part of the amendment was the clause fixing venue under the FELA in federal courts.

Under the venue clause an action can be brought in a federal court in a district

${ }^{\circ} \mathrm{Ibid}$.

This clause remained in Section 6 of the Federal Employers' Liability Act until it was stricken out by the Act of June 25,1948, c. $646, \S 18,62$ STAT. 989 , and its substance reenacted as a part of the Judicial Code, reading as follows:

"A civil action in any State court against a railroad or its receivers or trustees, arising under sections 5I-60 of Title 45 may not be removed to any district court of the United States." 28 U. S. C. $\$ 1445$, Act of June 25,1948, c. 646,62 Stat. 939.

This last amendment reworded the ban on removal so as to end the controversy over the question whether the ban applies to a receiver or trustee as well as to a railroad company. See Reviser's Note, 28 U. S. C. A. \$r 445.

47 "Mr. Bailey ... We are all familiar with the rule that when two courts have jurisdiction over the same subject-matter, the court whose jurisdiction is first invoked shall be permitted to proceed to a conclusion of the case. I only ask that that ancient and safe and just rule be written into this bill, so that if a citizen, in pursuance of the permission granted by the bill, does bring his suit in the state court, he shall not be dragged by the common carrier the distance of many miles and put to the burdensome expense incident to litigation in federal courts. That is so just and reasonable that it seems to me there would be no vote against it in all the Senate." 45 CoNG. REC. 4050 (I910).

"Mr. Dixon. I will frankly admit that my whole feeling is that these cases ought to be litigated in the locality where the cases arise and not be transferred to a foreign community or a foreign court." Id. at 4092.

${ }^{48} \mathrm{Id}$. at $4 \mathrm{I} 58$.

${ }^{10}$ See c. $143, \$ 1,36$ STAT. 291 . The portion of the bill dealing with venue, jurisdictions, and removal of suits, often loosely referred to as the venue clause, was added as a second paragraph to Section 6 of the FELA reading: "Under this Act an action may be brought in a circuit court of the United States, in the district of the residence of the defendant, or in which the cause of action arose, or in which the defendant shall be doing business at the time of commencing such action. The jurisdiction of the courts of the United States under this Act shall be concurrent with that of the courts of the several States, and no case arising under this Act and brought in any state court of competent jurisdiction shall be removed to any court of the United States." 
(I) of the residence of the defendant, or (2) in which the cause of action arose, or (3) in which the defendant is doing business at the time of commencement of the suit. ${ }^{50}$

On its face, this venue clause, as Senator Borah described it on the floor of the Senate, allowed the plaintiff a choice of venue among the three districts named. The third category, however, like the fourth category of the original bill, was broad enough to encompass practically the whole range of permissible venue since it is difficult to conceive of it being held that a defendant is not doing business at the place of its incorporation or at a place where by virtue of negligence in the conduct of its operations it occasions injury to an employee.

The language of the venue clause is fairly clear. The most important, if not the most numerous, questions arising regarding its interpretation have concerned not differences of opinion about the meaning of the language employed but the effect of the amendment upon other rules of law affecting the right to institute or maintain suit at a particular place.

Was the venue clause of Igro an ordinary venue rule? If so, it would have to be applied like any other ordinary rule of venue along with such other rules as those relating to change in venue, to the prohibition of suits burdensome on interstate commerce, to injunctions against vexatious or harassing litigation, and to forum non conveniens.

If on the other hand the amendment of IgIo was designed to create a special federal privilege of venue, then it would override other related rules of law, state and federal, ordinarily applicable in the same field.

The answer to the question regarding which of these two opposing theories represents the correct view is not to be found in the literal wording of the clause, as Chief Justice Vinson remarked in Ex parte Collett. ${ }^{51}$ The answer can only be found from a construction of the statute arrived at by considering the logical effect of the amendment under all of the circumstances, including the intent of Congress as disclosed by the legislative history.

The answer to be derived from any adequate consideration of the legislative history is reasonably clear. None of the collateral legal or equitable principles was mentioned in the hearings, reports or debates. It is clear from them, however, that Congress intended to create no special federal venue privilge but only to enact an ordinary venue rule similar to those in effect in the state courts. In doing so its chief purpose, reiterated time and again, was to provide a place of venue convenient to parties and witnesses, and particularly in the community where the plaintiff and his fellow workers live. The aim was not to facilitate but to stop suits at distant points. Practically everyone believed that the plaintiff would select the court in or as near as possible to his own community. The railroad witnesses at the hearing before the Senate subcommittee shared this view although out of an abundance

${ }^{50}$ Today the text of the venue provision is the same as set forth in the preceding note. It is quoted in note $I$, supra.

337 U. S. 55 at $6 \mathrm{r}$. 
of caution they sought to curtail the unrestricted venue provisions of the House bill. The Senate went so far as to modify the House bill in two important particulars to prevent the expanded venue from being used as a vehicle for the transportation of suits to distant forums. With the same end in view it banned the removal of a suit under the Act from a state to a federal court.

\section{Emergence of Long Distance Transportation of Lawsuits}

By an ironic twist of fate these venue provisions enacted into law for the very purpose of avoiding inconvenience and hardship to parties and witnesses by reason of the location of the place of trial have in large measure produced the opposite result.

The hardship on the plaintiff, it is true, has been relieved because the threefold choice afforded has served to permit him to institute an action everywhere within reason that the defendant corporation could be served with process. For the defendant and the witnesses the consequences have been vastly different. While in large metropolitan centers suits are frequently, but by no means always, instituted in local courts, elsewhere the prevailing practice is for claims not settled by agreement between employer and employee to be transported for suit hundreds or even thousands of miles away, making it inconvenient and annoying for the witnesses to attend the trial and rendering a satisfactory presentation of the defense costly and difficult at best and sometimes well-nigh impossible for the railroad.

Results such as these so contrary to the course of events anticipated on all sides in the commitee hearings and in debates on the floor in the House and the Senate have sometimes been ascribed to the disposition of an injured employee with a claim under the Act to shop around for a favorable judge or a generous jury. Quite true, the injured man or his home town lawyer may possibly survey the various courts and jurisdictions where the defendant may be doing business and then choose a court, state or federal, in some distant place, one, two or three thousand miles away. Perhaps an injured man may look over the members of the bar in his county and state and then, turning them down, decide to seek more renowned counsel in New York, Chicago, St. Louis or Oakland. These things, of course, have happened here and there, but it may be doubted whether anything of this sort has been a major factor.

Where suit is brought at a distant place it is usually because of the intervention of agencies wholly unanticipated by those who framed and put through the special venue clause-the systematic solicitation of personal injury claims by unethical lawyers in large cities, and, to a somewhat lesser degree, the pressure exerted by labor unions on their members to place personal injury claims in the hands of regional attorneys maintained by the unions in the larger centers. These agencies have developed a sizable racket around the dual opportunity for widespread solicitation and for harassment of the defendant which the very broad choice of venue affords.

The development of these practices seems to have commenced soon after the 
amendment of Igro. ${ }^{52}$ By rgr6 ambulance chasing had become one of the recognized evils in the operation of the FELA..$^{53}$ A sample cross-section of what was taking place is found in the opinion in Reed's Adm'x v. Illinois Cent. $R . R^{54}$ where the railroad brought suit in a state court of Kentucky to enjoin an action brought by the administratrix in a state court of Minnesota for damages for the death of her husband while in the employ of the railroad company in Kentucky. The claim had been transported for suit a thousand miles from the residence of the administratrix and of the witnesses for both parties. The railroad company charged that this resulted from the solicitation of the claim by Anderson, a Minnesota attorney who made a specialty of damage suits against corporations, employing agents or runners who were not lawyers in soliciting business for him in Kentucky and in various other places served by railroads with lines entering Minnesota. One of the runners, it was charged, had induced the administratrix to employ Anderson. The agreement provided he would investigate at his own expense the facts in relation to the case, pay all costs incident to the institution of the suit, make all bonds that might be necessary in its prosecution, pay from his own pocket the railroad fare, hotel bills, and other necessary expenses of witnesses whom it might be necessary to take from Kentucky to Minnesota, and in addition support and maintain the administratrix during the pendency of the suit. The court found that these averments were supported by the evidence, saying that it was inconceivable that the widow would freely or voluntarily leave her home and go to a distant state to bring suit. ${ }^{\text {tE }}$

${ }^{52}$ Mr. D. Lindley Sloan, formerly Chief Judge of the Court of Appeals of Maryland, who had lived and practiced in the railroad center of Cumberland in that state both before and after his service on the bench thus described some of the practices:

"Long before I went on the bench I knew about the practice which has grown up of lawyers and their runners from large cities coming into Cumberland, which is a large railroad center, and soliciting business from railroad men who had been injured or from the families of those who had lost their lives. Personally, it first came to my attention shortly after the passage of the Employers' Liability Act. . . .

"It was notorious around our county that every time a man was injured or killed in railroad service, and we had four railroads in the community, runners from everywhere were in here soliciting the big cascs." Hearings before Subcommittee No. 4 of the House Committee on the Judiciary on H. $R$. I639, 80th Cong., rst Sess. 40 (1947).

${ }^{53}$ See Ballantine, A Compensation Plan for Railway Accident Claims, 29 Harv. L. Rev. 705, 707 (19r6), giving as one reason for the adoption of a workmen's compensation act for railway employces the unwholesome situation created by the activities of the ambulance chasers:

"Besides this natural prejudice there is for the company the constant menace of fraud. Stirring up and prosecuting personal-injury cases has become the trade of certain attorneys. 'The 'ambulance chascr' is the tool that draws in their victims. In suits so instituted there is a premium upon perjury-perjury to establish liability, perjury to enhance damages. There are doctors who make a busincss of skilfully instructing plaintiffs in the simulation of injuries. To ward off verdicts often secured by such methods, it is almost inevitable that claim agents of companies should sometimes resort to sharp methods. A bad color emanates from the whole ficld of this personal-injury litigation."

See also Hubbell, Soliciting Out of Town Claims Against Railroads, 87 CENT. L. J. 48 (19r8).

${ }^{5} \mathrm{I} 82 \mathrm{Ky} .455,206$ S. W. 794 (I9I8).

55 The court said ( $182 \mathrm{Ky}$. at $468-469,206 \mathrm{~S}$. W. at 800 ):

"Under the laws of this state, and the practice and procedure in its courts, her chances of recovery would be as good as in the courts of the state of Minnesota; but, notwithstanding these favorable conditions and surroundings, she was persuaded by Anderson to bring her suit in the state of Minnesota about I,000 miles distant from her home, the place of the accident, and the residence of all the witnesses for both parties.

"We say she was persuaded by her attorney to do this because it is inconceivable that this woman, 


\section{Restrictions on Venue During Government Control of Railioads}

The transportation of personal injury claims for a great distance for the purpose of instituting suit under the Act soon attained large proportions. By the time the United States assumed possession of the railroads toward the end of $x 917$, placing them under the newly created Railroad Administration ${ }^{56}$ the defense of these suits had become a serious burden. It was not only costly, but during the manpower shortage of World War I it unnecessarily consumed the time of men engaged in the vitally important operation of trains carrying military traffic by requiring them to attend distant court as witnesses in suits brought under the Act. This practice, with its waste of essential manpower, was so prejudicial to the war effort that the Director General of Railroads by administrative orders put an end to the abuse of venue by requiring that all suits against carriers while under the federal control must be brought in the county or district where the plaintiff resided at the time of the accrual of the cause of action or in the county or district where the cause of action arose. These administrative orders were issued under powers given to the President and delegated to the Director General by Section ro of the Federal Control Act which specified that the carriers while under federal control should be subject to all laws and liability as common carriers except in so far as might be inconsistent with any provisions of that statute or with any order of the President. ${ }^{57}$ They were sustained by the Supreme Court as valid and reasonable.

The orders recited that the practice of bringing personal injury suits against railroads at remote places seriously interfered with the physical operation of the railroads and was not necessary for the protection of the rights or the just interests of the plaintiffs. ${ }^{58}$ They had the desired effect of curtailing abuses of venue while

under the undisputed facts as we have stated them, would freely or voluntarily leave her home and go to a distant state to bring this suit. ...

"Under these circumstances, we may well believe, and do so, that the administratrix, under the influence of Anderson, was induced to bring the suit in Minnesota in order that the railroad company might be subjected to great and unnecessary expense and inconvenience and for the purpose of vexatiously harassing and annoying it. Probably Anderson adopted this course with the expectation that the railroad company, rather than go to the expense and inconvenience that would attend its defense of the case in the Minnesota court, would pay a substantial sum in settlement; but, whether this was the moving cause or not, it seems clear to us that the only purpose of bringing the suit in the Minnesota court was to harass and annoy the company and subject it to as much expense and inconvenience as possible."

os The President took control of the railroads under a proclamation dated December 26, 1917, issued under the Act of August 29, I9r6, c. 418, $\$$ I, 39 STAT. 645 , 10 U. S. C. $\$ 136$ I. He operated them under that statute, supplemented by the Federal Control Act of March 2r, Igr8, c. 25, 40 STAT. 45r.

¿7 The orders of the Director General were held invalid in Friesen v. Chicago R. I. \& P. Ry., 254 Fed. 875 (D. Neb. 1918), and El Paso \& S. W. R. R. v. Lovick, 210 S. W. 283 (Tex. Civ. App. 1919). They were finally sustained by the Supreme Court in Alabama \& Vicksburg Ry. v. Journcy, 257 U. S. III, II 4 (192I). In that case the Court said:

"Section ro of the Federal Control Act of March 21, r918, c. 25, 40 Star. 451, 456, permitted enforcement of liabilities against carriers while under federal control except "in so far as may be inconsistent . . . with any order of the President.' It was within the powers of the Director General to prescribe the venue of suits; and the facts set forth in the order show both the occasion for it and that the venue prescribed was reasonable." See also Actions Against Railroads Under the Federal Control, 23 LAW Notes 46 (1919).

. ${ }^{68}$ General Order No. 18 of April 9, 1918, and General Order No. 18a of April 18, 1918, of W. G. McAdoo, Director General of Railroads. These two orders read as follows: 


\section{the roads continued in the hands of the Government.}

\section{Re-emergence of Venue Abuses After Federal Control}

When the railroads were returned to private ownership early in $1920,{ }^{60}$ the general orders of the Director General limiting venue lapsed and conditions reverted to those that had obtained prior to government operation. ${ }^{60}$ Extensive solicitation of personal injury claims under the Act began again. ${ }^{61}$ In Minnesota the institution of suits at great distances from the place where the cause of action arose as well as

"United States Railroad Administration. Office of the Director General, Washington. April 9, 1918. General Order No. $\mathbf{8} 8$.

"Whereas, the act of Congress approved March 2I, I918, entitled 'An act to provide for the operation of transportation systems while under federal control,' provides (section 10) 'that carricrs while under federal control shall be subject to all laws and liabilities as common carriers, whether arising under state or federal laws or at common law, except in so far as may be inconsistent with the provisions of this act or with any order of the President. ... But no process, mesne or final, shall be levied against any property under such federal control'; and

"Whereas, it appears that suits against the carriers for personal injuries, freight and damage claims, are being brought in states and jurisdictions far remote from the place where plaintiffs reside or where the cause of action arose, the effect thereof being that men operating the trains engaged in hauling war materials, troops, munitions, or supplies are required to leave their trains and attend court as witnesses, and travel sometimes for hundreds of miles from their work, necessitating absence from their trains for days and sometimes for a week or more, which practice is highly prejudicial to the just interests of the government and seriously interferes with the physical operation of the railroads, and the practice of suing in remote jurisdictions is not necessary for the protection of the rights or the just interests of plaintiffs:

"It is therefore ordered, that all suits against carriers while under federal control must be brought in the county or district where the plaintiff resides, or in the county or district where the cause of action arose.

"W. G. McAdoo, Director General of Railroads."

"April 18, 1918. General Order No. 18a. General Order No. 18, issued April 9, 1918, is hereby amended to read as follows:

"It is therefore ordered that all suits against carriers while under federal control must be brought in the county or district where the plaintiff resided at the time of the accrual of the cause of action or in the county or district where the cause of action arose.'

"W. G. McAdoo, Director General of Railroads."

${ }^{50}$ March $x$, 1920, pursuant to the Transportation Act of x920, c. 91, $4 \mathrm{I}$ STAT. 456.

${ }^{\circ 0}$ See Payne v. Knapp, 197 Iowa 737,198 N. W. 62 (I924).

${ }^{01}$ See, for example, Chicago, M. St. P. Ry. v. McGinley, 175 Wis. 565, 579, I85 N. W. 218, 223 (1921), where the court stated:

"Plaintiff herein also charges that the defendant's attorneys, in procuring the authority to prosecute defendant's action for personal injuries, were guilty of what is commonly known in the profession as 'ambulance chasing,' and that as the result of such employment so obtained, defendant's action is not being prosecuted in Minnesota in good faith, but from ulterior motives, primarily designed to promote the business of such counsel engaged in such reprehensible practice.

"That such practices have been indulged in extensively by counsel, both in the state of Wisconsin and in the state of Minnesota, is a matter well known to the profession and to the courts."

The wide prevalence of solicitation of railroad personal injury claims was sometimes pleaded in extenuation of individual conduct. "The undisputed evidence in the case is that it was the general report that all personal injury lawyers in Chicago had solicitors out. The fact that other personal injury lawyers had solicitors for the purpose of procuring business for them, however, is no justification in this case." People ex rel. Chicago Bar Ass'n v. McCallum, 34I Ill. 578, 590, 173 N. E. 827, 831 (1930).

The prevalence of the practice has also been recognized by law reviews and bar journals. Leading articles: Winters, Interstate Commerce in Damage Suits, 29 J. AM. Jw. Soc'y 135, x37 (x946); Barrett, The Doctrine of Forum Non Conveniens, 35 Calif. L. Rev. 380, 382 (1947); Gay, Ventle of Actions, 33 A. B. A. J. 659 (x947); Editorial: Interstate Commerce, 26 CHICAGo BAR ReCoRd 18r-182 (1945); Notes, 39 Yale L. J. 388, 399 (I930); 46 West VA. L. Q. 344, 346 (1940); I6 J. Bar Ass'N Kansas 233, 235 (1947); 10 Texas B. J. 499 (1947); 34 MinN. L. Rev. 145 (1950); 30 N. C. L. R'ev. 168 (1952). 
from any place where the defendant operated a line of railroad was fostered by a state statute allowing process to be served on any foreign railroad corporation having an office in the state for the solicitation of freight or passenger traffic. In I923 the Governor of the State asserted in a message to the Legislature that there were pending 1,028 personal injury cases brought by nonresident plaintiffs asking 26 million dollars in damages from railroads without trackage in Minnesota. ${ }^{62}$ Between 1920 and $x 924,224$ actions involving damages of more than 9 million dollars were brought against the Milwaukee Railroad in Minnesota where the cause of action arose outside of the state. ${ }^{63}$

The moving forces behind the transportation of personal injury claims under the FELA may be better appreciated after a review of case histories of some of the lawyers engaged in this class of litigation.

One of the leaders of the bar in this field of the practice in the era beginning with the return of the railroads to private control in 1920 was Robert J. McDonald of Minneapolis. His bold, aggressive activities in getting and retaining personal injury business made him a controversial figure for many years. Some of the controversies reached the courts. One of the first was Chunes v. Duluth, W. \& $P . R y{ }^{64}$ $\mathrm{McD}$ onald and his firm engaged in a hot dispute with another lawyer over the issue of which one had been duly retained to represent Chunes, an employee with a claim under the Act. Each charged the other had solicited the case. Judge McGee, apparently believing both were right, dismissed the suit, holding that neither firm had any authority to institute suit on behalf of the plaintiff. McDonald shocked the judge by boldly admitting in open court that he indulged in ambulance chasing. ${ }^{65}$

02 This message is summarized in a footnote in Davis v. Farmers Co-operative Co., 262 U. S. 312 (r923), at 316 , as follows:

"A message, dated February 2, I923, of the Governor of Minnesota to its Legislature, recites that a recent examination of the calendars of the district courts in 67 of the 87 counties of the State disclosed that in those counties there were then pending 1,028 personal injury cases in which non-resident plaintiffs seek damages aggregating nearly $\$ 26,000,000$ from forcign railroad corporations which do not operate any line within Minnesota."

In that case, the Court described the practices current before, during, and immediately after federal control, as follows:

"That the claims against interstate carriers for personal injuries and for loss and damage of freight are numerous; that the amounts demanded are large; that in many cases carriers deem it imperative, or advisable, to leave the determination of their liability to the courts; that litigation in States and jurisdictions remote from that in which the cause of action arose entails absence of employees from their customary occupations; and that this impairs efficiency in operation, and causes, directly and indirectly, heavy cxpense to the carriers; these are matters of common knowledge. Facts, of which we, also, take judicial notice, indicate that the burden upon interstate carriers imposed specifically by the statute here assailed is a heavy one; and that the resulting obstruction to commerce must be serious. During federal control absences of employees incident to such litigation were found, by the Director General, to interfere so much with the physical operation of the railroads, that he issued General Order No. r8 (and I8A) which required suit to be brought in the county or district where the cause of action arose or where the plaintiff resided at the time it accrued. That order was held reasonable and valid in Alabama \& Vicksburg Ry. Co. v. Journey, 257 U. S. III. The facts recited in the order, to justify its issue, are of general application, in time of peace as well as of war." Id. at 315-316.

${ }^{03}$ Weinard v. Chicago, M. \& St. P. Ry., 298 Fed. 977 (D. C. Minn. 1924).

ot 298 Fed. 964 (D. C. Minn. I924).

os "On the hearing of the motion to remand, in which his firm represented the plaintiff in another personal injury case heard about the same time, Mr. McDonald was charged by the opposing attorney with practicing 'ambulance chasing;' and replied, admitting the fact. In answer to a question from the 
The judge thought "The situation described in the affidavits is one calculated to make anyone with a love for the legal profession blush with shame, and apparently is the natural resultant and product of the very demoralizing practice which has grown up in the legal profession in the large cities, and which has done so much to debase and degrade the honorable profession of the law."Bc Judge McGee ordered a copy of his opinion and of the record to be sent to the State Board of Law Examiners of Minnesota "for such action as to that body may seem appropriate."

Judge McGee entered the same sort of an order in another case, Weinard $v$. Chicago M. \& St. $P$. Ry., ${ }^{68}$ which was before him at about the same time. McDonald's firm had brought suit under the Act in the federal district court in Minneapolis on behalf of Weinard who had sustained an injury while in the employ of the Milwaukee Railroad in Tacoma, $\mathrm{r}, 787$ miles away. An affidavit in support of a motion to dismiss the suit as a burden on interstate commerce set forth that McDonald's firm and many other lawyers in Minneapolis were engaged in ambulance chasing on a large scale in FELA cases. Although these statements in the affidavit were based on information and belief, the court accepted them as substantially true largely because the McDonald firm pointedly avoided any real denial..$^{69}$

In $1929 \mathrm{McDonald}$ and his associates were still flourishing in Minnesota, Wisconsin, and elsewhere as ambulance chasers. In Chicago, M. St. P. \& P. Ry. v. Wolf ${ }^{70}$ the railroad brought several actions in a state court in Wisconsin to enjoin

court if he realized the nature of the admission he had just made, he replied: 'Of course I do. It is the truth, and why not admit it?' ...

"There does not seem to be the slightest thought on the part of any of the attorneys mentioned that the practice referred to is in violation of the ethics of the legal profession and brands those who indulge in it with professional infamy." Id. at 976.

${ }^{\circ}$ Ibid.

${ }^{07}$ Id. at 977 .

${ }^{68} 298$ Fed. 977 (D. C. Minn. 1924).

${ }^{80}$ The affidavit recited in part:

"(3) That the plaintiff's attorneys, since the expiration of General Orders Nos. 18 and $18 \mathrm{~A}$ of the Director General of Railroads of the United States, have employed and 'maintained solicitors of such claims and actions, and that such solicitors, as affiant is informed and believes, reside or travel about in most, if not all, of the states above mentioned, as well as other states, soliciting such claims and actions against the defendant and other railroad companies. . . .

"(4) That beside said firm . . . there are other attorneys residing in the cities of St. Paul and Minneapolis, Minn., in number more than 15, who are likewise engaged in the practices aforesaid; that said practices have resulted in the bringing of great numbers of suits in Minnesota by the attorncys engaged in such soliciting against railroad companies not residents of Minnesota, in which the causes of action arose outside of and the plaintiffs were nonresidents of the state of Minnesota. . . " Id . at $98 \mathrm{r}$.

${ }^{70} \times 99$ Wis. $278,226 \mathrm{~N}$. W. 297 (1929). The lower court had found among other things:

"That said attorneys have offices in the Baker Building in the City of Minneapolis, in said State, and that for more than a year prior to April, 1928, and thereafter at the various times mentioned in the foregoing findings and those hereinafter contained, conducted and maintained a 'high-pressure, highpowered' department, thoroughly organized, for the purpose of soliciting legal business in the State of Wisconsin, and other States, through men of experience in this line of activit employcd by said firm to do the work commonly termed 'ambulance chasing,' and that in the maintenance of said departinent said law firm annually expends, conservatively stated, in excess of $\$ 100,000$ by way of advancements to clients and salaries and other expenses of the persons employed in said department.

"That since September, 1926, Tautges, Wilder and McDonald had in their employ in the State of Wisconsin one Jacob J. Stahl, a legal resident of Milwaukee, Wisconsin, whose business was to visit 
Wolf and Hoch from prosecuting personal injury suits against the company in Minnesota. The McDonald firm, as attorney for Wolf and Hoch, was joined as a defendant, it being alleged that they had obtained the cases by solicitation and were engaged in a highly organized scheme of ambulance chasing on a large scale. The Wisconsin Supreme Court found that McDonald was engaged in ambulance chasing as charged, but that the injured men were guilty of no wrong so that the case was the same as though they had voluntarily gone to Minnesota and commenced the action which they had the right to do. The actions were therefore dismissed.

In the Wolf case there was ample evidence of McDonald's solicitation activities. His own testimony established the fact that the solicitation carried on by him and his chasers was supported by such features as advances to clients and the use of investigators paid on a contingent basis. ${ }^{71}$ In fact, McDonald, as he had done in the Chunes case, readily admitted he solicited personal injury claims; ${ }^{72}$ his testimony led to a strong denunciation of his tactics and his attitude by Chief Justice Rosenberry. ${ }^{73}$

injured railroad employees and induce them to employ Tautges, Wilder and McDonald as their attorneys and bring suit against the Railroad Company in the State of Minnesota; that said Stahl's work permits of his presence at his home in Milwaukee for only a few weeks of each year; that prior to his employment by Tautges, Wilder and McDonald in September, I926, the said Jacob J. Stahl had been in the cmploy of another firm of attorneys at Minneapolis, in a similar capacity; that said Tautges, Wilder and McDonald also employ one E. L. Harrigan as Superintendent of said Soliciting Department at a salary of $\$ 10,000$ per year; that said Jacob J. Stahl and four other persons, similarly engaged, are cmployed by said law firm at salaries of $\$ 300$ a month, and that all of said employees are also provided with allowances for all their traveling, hotel and other expenses amounting to considerable sums of money each month." I99 Wis. at 282,$283 ; 226$ N. W. at 298.

72 "It is quite apparent from the testimony of the witness that he traveled about the country soliciting business, working in conjunction with solicitors of the firm, saw that sums were advanced to clients and that the firm paid the expenses of litigation secured by him. Some inkling of the methods pursued by this firm may be gained from the testimony of the witness to the effect that none of the expenses of the investigators are charged to clients, but are paid by the firm; that the firm maintains a slush fund and entertainment fund; that the investigators were paid about $\$ 300$ a month, some of them work on a commission basis, which amounts to 40 per cent of the net fees obtained by the firm. The firm also maintains a corps of expert witnesses. The firm annually loans to clients $\$ 50,000$, annually pays to Harrigan, chicf of the soliciting force, $\$ 10,000$; pays to investigators annually a total of $\$ 18,000$, and has other annual expenses of $\$ 40,000 . "$ rg9 Wis. at $284-285,226 \mathrm{~N}$. W. at 299 .

72 "Robert J. MCDonald, one of the firm, appeared and testified as a witness in the case, and it was established beyond any doube by the admissions of McDonald that the findings of fact were fully sustained. Reference was made to the case of Chunes v. Duluth, W. \& P. Ry. Co. (D. C.) 298 F. 964 , where United States District Judge McGee in his opinion stated that Mr. McDonald had admitted that he indulged in the practice of ambulance chasing." 199 Wis. at $284,226 \mathrm{~N}$. W. at 298 .

73 "The conduct of the attorneys in this case is not only unethical and shocking to the professional conscience of any right-thinking lawyer, but violative of ordinary professional decency. 'The conduct of the lawyer who was described as 'flying the black flag of piracy' (Ellis v. Frawley, I65 Wis. 38I, I6I N. W. 364 ) was almost innocent compared with what was done by this firm of attorneys in securing business. The only refreshing note in the whole sordid mess is the breezy buccaneer-like confidence of Mr. McDonald, apparently born of association with an organization so invincible that he feels safe not only in violating the laws of a sister state and the canons of professional ethics, but in flaunting the violation in the face of his accusers as if to say, "Here it is, what are you going to do about it?", 199 Wis. at $286,226 \mathrm{~N}$. W. at 299 .

"That an organization such as Tautges, Wilder \& McDonald maintaining a corps of expert witnesses, employing high-powered solicitors, using slush and entertainment funds to secure business, and no doubt for other purposes, are a menace to the proper administration of justice cannot be doubted. Having secured business at a large expense, advanced funds to clients, their interest is not as officers of the court in seeing that justice is fairly administered, but that a verdict is secured in 
Finally, the State Board of Law Examiners of Minnesota brought an action to disbar McDonald. The Minnesota Supreme Court found that he had engaged in organized solicitation of personal injury cases: In re $\mathrm{McDonald}^{\mathbf{7 4}}$ The court pointed out that while the disbarment proceedings were pending, McDonald continued to have his brother, Donald, and other chasers solicit cases, armed with such persuasive equipment as photostatic copies of checks and newspaper clippings attesting to McDonald's success in other cases. ${ }^{75} \mathrm{He}$ was ordered disbarred with permission to apply to the court for reinstatement at the end of three years and upon presentation of proof that in the meantime he had not directly or indirectly practiced law. Thus fourteen years after Judge McGee's indignant dual citation, McDonald's large scale ambulance chasing was subjected to a judicial check. But not for long.

In I940, McDonald was reinstated: In re Reinstatement of Robert J. McDonald.70 In a per curiam decision, the court pointed out that McDonald's conduct "since the entry of the judgment of disbarment has been such as to indicate a complete change of attitude toward the standards of ethics governing the conduct of members of the profession."77

In the petition for reinstatement McDonald had expressed an intention not to specialize in negligence cases if he should be reinstated, asserting his intention to apply for admission to the bar in California and to specialize "in a field entirely removed from negligence cases."78

each case which will protect their investment and secure to them the fruits of their illicit enterpriscs. That these attorneys, being as they are officers of a court charged with important dutics in the administration of justice, can openly prostitute their high calling and go unpunished-not only unpunished but unrestrained-seems incredible and if such is the case, the facts constitute a strong indictment of the courts. The power of courts to maintain the integrity of the law and keep the channels of justice open and pure is very great. For that purpose they have broad inherent powers not dependent upon acts of the Legislature and a responsibility to society which is as great as their powers." I99 Wis. at 289 , $226 \mathrm{~N}$. W. at $300-30 \mathrm{r}$.

The court concluded that:

"One reads Mr. McDonald's testimony in vain for any indication of what he would consider unethical conduct." 199 Wis. at $285,226 \mathrm{~N}$. W. at 299.

T4 204 Minn. 6r, 282 N. W. 677 (r938).

75 "He finally conformed to the request of the board that he discharge Donald and change his relations with attorneys sharing his office. But, all this notwithstanding, we find that even after this proceeding was begun the same sort of solicitation by persons provided with photostatic copics of checks and newspaper clippings was going on (Winterwerber case). As already intimated in the alleged systematic or planned solicitation of cases, the agent or solicitor usually appeared armed with photostatic copies of large checks received in cases tried or settled by respondent and newspaper clippings of cases handled by him, and a short form of contract engaging respondent as attorncy. Respondent designated Donald and others employed as investigators of the accidents involved; but it is noticed that their chief objective was the securing of the signature of the injured person to the contract employing respondent." 204 Minn. at 69,282 N. W. at $68 x$.

The court also made the following observations on the use by $\mathrm{McD}$ Donald of various devices as an aid in soliciting cases:

"We may also say that respondent's testimony that he never authorized the use of photostatic copics of checks or newspaper clippings by his solicitors, only having such for his own use to impress claim agents with what he could secure from juries, is past belief." $204 \mathrm{Minn}$. at 7r, $282 \mathrm{~N}$. W. at 682 .

${ }^{76} 208$ Minn. 330, 294 N. W. 46r (InAo). ${ }^{77} 208$ Minn. at 33r, 294 N. W. at $46 \mathrm{r}$.

78 ". . . Upon Admission to the Bar in California, petitioner will engage in the general practice of law with special emphasis upon those features thereof relating to the motion picture industry and in a field entirely removed from negligence cases. ..." Petition filed with Minnesota Supreme Court in its Docket 30755, pp. 4-5. 
The extent to which McDonald, following his reinstatement, actually carried out this announced intention to specialize "in a field entirely removed from negligence cases" up to the time of his death in 1947 is revealed by papers in Probate Court File No. 68616, In re Estate of Robert J. McDonald, Decedent, in Hennepin County, Minnesota.

The administrator's "Petition for Authority to Operate Business of Decedent and to Expend Funds Therefor" reveals that at the time of his death McDonald "specialized in handling personal injury litigation," having 150 such actions pending in his office. ${ }^{7 \theta}$

A report, filed August 25, 1949, by the administrator, shows that to June 30 of that year, he had received in cash from lawsuits pending at the time of McDonald's death net fees amounting to $\$ \mathrm{I}, \mathrm{III}, 935.42$. With the inclusion of fees paid to associate counsel and reimbursement of loans and advances to clients, the sum total received by the administrator and associate counsel from pending cases was $\$ 2,075,530$. The report casts a significant light on one method employed in getting legal business in a highly competitive field. "In one case, however," it goes on to say, "the recovery was less than the amount which Mr. McDonald had guaranteed to his client and therefore the entire amount recovered was turned over to the client, in which case the estate and associate counsel were without fees and could not be reimbursed for costs and expenses."

William Wallace McCallum, a Chicago lawyer, was a contemporary of McDonald, and likewise engaged in personal injury practice under the FELA. The Chicago Bar Association, having received complaints against his methods of securing clients, preferred charges which reached the Supreme Court of Illinois in People ex rel. Chicago Bar Association v. McCallum. ${ }^{80}$ While refusing to disbar McCallum, the court held that charges of solicitation had been proven and accordingly pronounced "severe censure." The court stated that while the offense of solicitation did not import "venality, criminality, fraudulent practices, or moral turpitude," such offenses cannot lightly be passed over. ${ }^{81}$

${ }^{70}$ Pertinent parts of the petition are as follows:

". . . That at the time of his death the decedent ... specialized in handing personal injury litigation for plaintiffs in actions against financially responsible defendants and was nationally reputed to be a successful personal injury attorney and had clients and cases pending in various states in the Union. ... That at the time of his death the decedent was attorney for the plaintiff in more than 150 cases involving very substantial claims."

${ }^{80} 34$ I III. 578 , 173 N. E. 827,832 (I930).

s1 "Much evidence was heard on the subject of solicitation of business. The railroad company, with the aid of two of respondent's employees whom it had corrupted, after the expenditure of much time and money in interviewing former clients of respondent, produced some who testified that their cases had been solicited by persons purporting to represent respondent, while respondent produced many of his former clients to testify to his fair dealing and that they had taken their cases to him by reason of his general reputation among the railroad men as to his success in personal injury cases. Railway Men's Union officials testified as to his reputation in that respect among the Railway Union men. Respondent testified that he had not personally solicited any claim. When the evidence is all considered we are of the opinion that it shows some solicitation on the part of persons purporting to represent respondent and that he had knowledge of such solicitation. The undisputed evidence in the case is that it was the general report that all personal injury lawyers in Chicago had solicitors out. The fact that other personal injury lawyers had solicitors for the purpose of procuring business for them, however, 
McCallum did not profit by the warning. He continued to seek clients by the same methods. New charges were filed against him: In re $M c$ Callum. ${ }^{82}$ In this proceeding, it was held again that charges of solicitation had been proven and the court ordered his name stricken from the roll of attorneys. The court commented in detail on examples of solicitation described by nine different witnesses and concluded that there was sufficient basis for believing he had engaged in the practice. ${ }^{83}$ The court noted respondent's careful efforts to avoid charges of solicitation. Each personal injury client, at respondent's request, signed an affidavit purporting to describe the circumstances under which he happened to employ the lawyer. "It seems to have been the custom of respondent," the court remarked, "to obtain from each client an affidavit that he was not solicited to employ respondent to represent him. In view of the evidence in the record as to the manner in which such affidavits were obtained, this custom was, in itself, significant." ${ }^{\prime 4}$

To rebut the testimony of one of his clients who had accused him of soliciting cases, the respondent introduced a letter dated July 7,1938 , in the client's handwriting, addressed to him stating that McCallum had been recommended to the writer and asking him to call. On cross-examination the client asserted that this letter actually had been written by him the following December and that he had copied it in longhand from a typewritten letter furnished by respondent's secretary.

To refute the testimony of one of his former solicitors who had complained to the Chicago Bar Association regarding his conduct, respondent produced a letter to the Bar Association written by the former solicitor in which the writer stated that the charges of solicitation which previously he had brought were erroneous. On cross-examination, the ex-solicitor stated that the letter to the Bar Association withdrawing the charges of solicitation had been prepared by respondent and that he signed the letter when the former paid him the sum of $\$ 320$ in settlement of a disputed debt.

While the court confined its disbarment ruling to the evidence of solicitation, the opinion states that "one other specification of misconduct deserves notice." misconduct in question related to a trial in Indiana on criminal charges of solicitation brought against one of McCallum's admitted employees, who was being defended by him. The judge who presided at the trial testified that after a verdict of guilty had been returned and while a motion for a new trial was pending, McCallum invited him (the judge) to go on an expense-paid trip to Florida.

The Illinois Supreme Court, January 10, 1950, without a written opinion, entered an order restoring McCallum to the roll of attorneys.

\footnotetext{
is no justification in this case. Its only relevancy is that it is one of the circumstances to be considered, together with all the other evidence in the case, as to respondent's motive and intention." $34 \mathrm{I}$ Ill. at 590, r73 N. E. at $83 \mathrm{I}$.

${ }_{82} 39 x$ Ill. 400,64 N. E. 2 d 310 (1945).

${ }_{83}$ "It is undisputed that these employees, with respondent's knowledge, solicited cases for him; that they operated in several States; that on numerous occasions they took cases and prospective clients to respondent and respondent's office; that respondent entered into contracts of employment with such clients and handled their cases." $39 \mathrm{I}$ Ill. at $4 \mathrm{I} 5,64$ N. E. $2 \mathrm{~d}$ at 316.

${ }^{84} 39$ I Ill. at 405,64 N. E. $2 d$ at 3 I2. $\quad 39$ Ill. at 414,64 N. E. $2 d$ at 316.
} 
Sol Andrews, another Chicago lawyer, commenced about r945 to get a considerable number of cases under the FELA from California, Arizona, New Mexico, Oregon, and Nevada. In a few months he had filed in the Chicago courts, state and federal, about eighty-seven suits against the Santa Fe and the Southern Pacific in which judgments totalling $\$ 4,915,000$ were demanded.

Evidence was uncovered that he had established a well-knit soliciting organization with headquarters in Chicago and Los Angeles. His runners represented to injured railroad employees in the western states that actions would be commenced on their claims in the courts of Chicago; that the railroads would have difficulty in producing witnesses at such a distant point, and to avoid the extraordinary expense of defending the case in a distant forum they would be likely to agree to liberal settlements; that large verdicts could be obtained from Chicago juries; and that all expenses of maintenance of the injured person during the pendency of the action, as well as all expenses of litigation, would be provided by the attorney and his associates and deducted from the recovery. ${ }^{86}$

In order to guard against prosecution for soliciting cases and fomenting litigation, Andrews followed the practice of requiring the solicited person to write a letter to the attorney stating that he had heard of the great ability and experience of the attorney in the personal injury field and inquiring whether the attorney would consider taking the case. Where the runner neglected to obtain such a letter in advance, the attorney required the injured person to write a pre-dated letter to perfect the record of employment. A retainer agreement was entered into on a blank form furnished by the attorney and, whether executed in the west at the request of the runner or in Chicago at the request of the attorney, was always dated at least a week or ten days later than the letter requesting the attorney to take the case. The letter and the agreement ordinarily were mailed to the attorney in Chicago by air mail in separate envelopes, and the attorney would reply to the injured man that he would consider the case and would suggest that the latter come to Chicago for an interview and medical examination. The prospect was transported to Chicago at the expense of the attorney, often by air, and was given sums ranging from $\$ 100$ to $\$ 400$ as an advance, supposedly for living expenses. Other advances were made from time to time pending the disposition of the claim. The total advances ranged from $\$ 150$ to more than $\$ 4,000$ in individual cases so that the attorney after about nine months of operation had invested in the venture about $\$ 200,000$. The runners were ostensibly on the payroll as investigators with fixed salaries. The amounts paid to them were in fact advances under a percentage arrangement. The chief runner had an agreement with the attorney to receive one-third of his fee, or one-ninth of the recovery. Assistant runners likewise received a commission, usually one-third of the chief runner's percentage. ${ }^{87}$

${ }^{86}$ Atchison, T. \& S. F. Ry. v. Andrews, 338 Ill. App. 552, 566, 88 N. E. $2 d{ }_{364}$ (x949). Statement of Floyd E. Thompson, Hearings before a Subcommittee of the Senate Committee on the Judiciary on S. 1567 and H. R. 1639 , 8oth Cong., $2 \mathrm{~d}$ Sess. $47-48$ (1948).

${ }^{87}$ Statement of Floyd E. Thompson in Hearings, supra, at 47-49. 
It is no wonder that the extent and audacity of this scheme provoked the judge in the trial court to declare that, ${ }^{88}$

It is conceivable that if all had gone well with the scheme Chicago would have become the personal injury litigation capital of the United States. Its courts would have become clogged with cases filed by plaintiffs living in distant places concerning facts which occurred far from the scene of the trial and testified to by witnesses brought great distances.

An injunction was granted against this scheme at the suit of the two railroad companies after an extended trial and was upheld on appeal. ${ }^{80}$

These case histories would not be complete without considering the role played by lawyers affiliated with the so-called legal-aid departments of a few of the railroad unions. ${ }^{90}$

In the arrangements that have come to light in the reported cases, the attorneys in these bureaus take the cases of injured members of the union on contingent fee contracts. Arrangements of this kind, although upheld in at least one case, ${ }^{01}$ have been condemned in others.

In In re $O^{\prime} N e i l l{ }^{92}$ an investigator for the Brotherhood of Railroad Trainmen sought to induce one of the members of the organization to retain O'Neill, its New York regional counsel. The attorney was employed under a written contract of retainer which provided for a contingent fee of 20 per cent, one quarter of which the attorney agreed to pay to the Brotherhood to be applied to the maintenance of its Legal Aid Bureau. During the course of the proceedings the contractual arrange-

${ }^{88}$ Opinion of Judge Ulysses S. Schwartz in Atchison, T. \& S. F. Ry. v. Andrews, Sup. Ct. of Cook County, Illinois, Gen. No. $46 \mathrm{~S}-4586$, quoted by Illinois App. Court in Atchison, T. \& S. F. Ry. Co. v. Andrews, supra note 86 , at 559 .

${ }^{80} 338$ Ill. App. 552, 88 N. E. 2 d 364 (1949). "The evidence in support of the charges of champerty and maintenance shows a brazen contempt for the law, legal ethics, and the rights of plaintiffs. The practice of champerty and maintenance reached a new low level when members of the intant conspiracy induced, by promises of reward, certain Santa Fe employecs to secretly enter into the conspiracy against their employer.

As stated by the chancellor, "This is no simple case of ordinary solicitation of law business by a lawyer.' The evidence shows that the extra expense for each of the railroads in defending the suits approximately 2,000 miles from the place where the causes of action arose would amount to more than \$ro0,000, at least. Plaintiffs argue, with force, that the damages caused by the unconscionable scheme of defendant Sol Andrews to enlist employees of plaintiffs to serve him to the injury of their employers cannot be measured in dollars. It is not strange that no champerty nor maintenance case has been found that is comparable to the instant one. In view of the magnitude, nature and purpose of the conspiracy charged, the instance case is sui generis. $338 \mathrm{Ill}$. App. at $567,568,88 \mathrm{~N}$. E. $2 \mathrm{~d}$ at $37 \mathrm{r}$.

00 "Many of the transported cases are traceable to the activities of the so-called legal-aid departments of certain of the railroad-employee labor unions. These departments are established chiefly for the purpose of assisting their members in prosecuting their claims for personal injuries, and for selecting certain lawyers and law firms in various cities, which lawyers are designated 'regional counsel.' As soon as possible after an accident occurs, an investigator, member of the brotherhood, intervicws the injured man, advising him what his claim should be worth, and informs him of the legal services which the brotherhood has made available to him. The regional counsel of the brotherhood are paid on a percentage basis in the event of recovery. Up until June 1946 the arrangement was that the regional counsel would receive 25 per cent of the recovery and thereafter remit 4 per cent of the recovery, from his fee, to the brotherhood for its services in procuring the case for him." House REp. No. 613, 8oth Cong., Ist Sess. 5 (1947).

${ }^{91}$ Ryan v. Pennsylvania R. R., 268 Ill. App. 364 (1932).

${ }_{52}$ F. Supp. 465 (E. D. N. Y. 1933 ). 
ment was altered. Two new agreements were substituted for the original one. Under the first the client employed O'Neill promising to pay a contingent fee of I5 per cent. By a special agreement the client agreed to pay the Legal Aid Department a contingent fee of 5 per cent to cover its investigatory services. The court held that there was no difference in principle between the use of two contracts instead of one and that both arrangements were in violation of the applicable Canons of Ethics, particularly the provision forbidding any payment or reward directly or indirectly to those who influence the bringing of cases to a lawyer's office as well as the further provision that while a lawyer may accept employment from an organization to render legal services in any matter in which the organization, as an entity, is interested, this employment should not include legal services to the members in respect to their individual affairs. ${ }^{93}$

The Supreme Court of California reached the same conclusion in another case involving the Legal Aid Bureau of the Brotherhood of Railroad Trainmen. ${ }^{94}$ Three successive arrangements between the Legal Aid Bureau and Hildebrand and his firm, who were regional counsel in California, were reviewed and condemned. ${ }^{95}$ The first plan called for a case to be handled by regional counsel on a 20 per cent contingent fee basis, the attorney agreeing to turn over one-fourth of that amount to the Brotherhood for maintenance of the Legal Aid Department. Under the second plan the claimant was required to sign two contracts covering an aggregate contingent fee of 25 per cent, one calling for ig per cent to counsel for legal services and the other for 6 per cent to the Brotherhood for its Legal Aid Department. The third arrangement permitted the counsel to handle the cases on a flat 25 per cent basis but required him to pay the investigators, members of the Brotherhood's staff, on a quantum meruit basis for their services. The case was not one where injured members of the union, acting on their own motion, merely went to the designated regional counsel to avail themselves of his services. While they were theoretically left entirely free to employ or not to employ regional counsel or someone else, actually they were subjected to solicitation and pressure to engage him..$^{96}$

\footnotetext{
${ }^{03}$ The district court noted that members of its bar expressly undertook to abide by the Canons of Ethics of the New York State Bar Association and that Canon 28, relating to rewards to those who bring cases to an attorney's office, and Canon 35, applying to employment by an organization such as an association, club or trade organization, were transgressed by the attorneys in this case. Id. at 465 , $466-467$.

o4 Hildebrand v. State Bar of California, 36 Cal. 2d 504, 225 P. 2d 508 (1950).

${ }^{O C} 36$ Cal. $2 \mathrm{~d}$ at 508-5I4, 225 P. $2 \mathrm{~d}$ at 5I0-5Ir.

oo "While the members of the Brotherhood were not compelled to employ regional counsel for the handling of their lawsuits, they were subject to continuous and strong recommendation from the Brotherhood to do so through its journal publications and circulars to the members, as well as by personal visits from officers of the Brotherhood locals advising the injured railroad men and their familics to avail themselves of the benefits furnished by the Legal Aid Department, embracing selected investigating and legal services. ... There is no question from the record but that petitioners knew exactly how their professional employment by injured railroad men was being solicited for them through the Brotherhood's activities, and they were willing to perform the desired legal services at a substantially reduced contingent fee rate in the belief that the volume of business to be directed to them through such solicitation would warrant such financial consideration." $36 \mathrm{Cal}$. 2d at 509, 225 P. $2 \mathrm{~d}$ at $5 \mathrm{II}$.
}

Hildebrand had been regional counsel for the Brotherhood since 1933. In a previous case, the 
A subcommittee of the Senate Judiciary Committee in 1948 reported that in the five years from I94I to I946 a total of 25 I2 suits were filed under the Act in districts other than where the accident took place or the plaintiff lived. These filings were then on the increase. Between July 1946 and September 1947 the rate was 70 per cent above the average for I94I-I946. Most of the importation was centered in five states; Illinois, California, New York, Minnesota, and Missouri, which together accounted for $9 \mathrm{I}$ per cent of the transported cases. Of the Illinois suits, 80 involved accidents in California, 44 accidents in Arizona, 37 accidents in New Mexico, and I59 accidents in Pennsylvania..$^{97}$

Subsequent compilations show a continuation of the practice. While the average annual rate at which the transported suits were filed was 500 a year in $x 94 x-1946$ and 842 a year in $1946-1947,{ }^{98}$ it reached a peak of 1,152 in $1947-1948$, and then declined to an average of 620 in $1948-1952$. The improvement after 1948 reflects the influence of the transfer rule under the principle of forum non conveniens in Section I404(a) of the Judicial Code ${ }^{99}$ which became effective September I, I948. But there was no corresponding change for the better in state courts considered as a whole. Despite the improvement in federal courts, the rate of importation in 1948-1952 while substantially below the peak, nevertheless exceeded that for I94I-I946, indicating continued trouble in the state courts.

\section{Stemming the Tide of Impported Lawsuits-Proceedings Against the Attorney}

Many legal remedies have been tried in the effort to stop the transportation of claims for suit at a distance with its attendant evils including solicitation. With the exception of General Orders 18 and I8a of the Director General of Railroads during World War I, none of these remedies has proved generally effective.

Disciplinary action against the soliciting lawyer by bar associations, state or local, has in practice proved inadequate. In many jurisdictions the prosecution is undertaken by members of bar association committees who serve without pay and who find it impracticable to devote as much of their time and attention to these matters as is required for seeing the case through to a conclusion. Since the solicitation racket is carried on underground and often directed by astute lawyers, it is quite difficult to detect and to obtain evidence against those who are engaged in it. All of those who are involved in the racket, the ambulance chasing lawyer, the runner or solicitor in his employ, and the client who becomes enmeshed in their toils, usually consider that they have reasons founded in self-interest to maintain silence about their conduct. It is extremely difficult to uncover the operations of one of the ambulance chasing rings. Even then it is difficult to put them out of business.

Board of Governors of the State Bar of California had recommended that he be suspended from the practice of law for a period of six months for solicitation, but the Supreme Court ordered dismissal of the charges after a review of the evidence which it said was conflicting and therefore "not of that clear and convincing nature which is necessary to establish a finding of culpability on the part of the accused." Hildebrand v. State Bar of California, 18 Cal. 2d 816, 834, I17 P. 2d 860, 869 (1941).

${ }^{27}$ Report to Senate Judioinat Conmitiee by Subcommitee No. 4, 8oth Cong., $2 d$ Sess. 6 (1948).

${ }^{98}$ Ibid.

${ }^{90} 28$ U. S. C. \$1404a. 
Injunction suits have been instituted against the lawyer who heads the ring-sometimes successfully, ${ }^{100}$ sometimes unsuccessfully ${ }^{101}$-but this is ordinarily not a practicable remedy and resort to it has been rare because the effort and expense incident to the requisite investigation preliminary to such an action is ordinarily prohibitive. ${ }^{102}$

Prosecutions by state and local authorities for violation of the laws against champerty, maintenance, barratry, and solicitation are sometimes undertaken, ${ }^{103}$ but campaigns to enforce these laws are sporadic and have not served to stem the tide. State and local laws are easily evaded by the ambulance chasing lawyer who sends his runner across state lines and who withdraws him quickly when the local authorities begin an investigation. None of these remedies-criminal prosecution, disciplinary proceedings, or injunction suits-is completely efficacious either singly or collectively. Indeed they usually fall far short of stamping out the evil. This is particularly true where the ambulance chaser solicits cases not in his own locality but through runners who travel into other and sometimes distant states to gather

${ }^{100}$ Atchison, T. \& S. F. Ry. v. Andrews, 338 Ill. App. 552, 88 N. E. $2 d 364$ (1949); Chicago, B. \& Q. R. R. v. Davis, III Neb. 737, I97 N. W. 599 (I924); McCloskey v. San Antonio Public Service Co., 51 S. W. 2 d 1088 (Tex. Civ. App. 1932); see also, Chicago, M. St. P. \& P. R. R. v. McGinley, I75 Wis. 565, I85 N. W. 218 (I92I); Reed's Adm'x v. Illinois Cent. R. R., I82 Ky. 55, 206 S. W. 794 (I918).

${ }^{101}$ Chicago, M. St. P. \& P. R. R. v. Wolf, rg9 Wis. 278,226 N. W. 297 (1929).

${ }^{102}$ Mr. Thomas B. Gay, Chairman of the Committee on Jurisprudence and Law Reform of the American Bar Association, testifying before the House Committee on the Judiciary, April 18, 1947, said that prosecutions and disbarment proceedings are inadequate:

"Perhaps all bar organizations, whether voluntary or statutory, provide machinery and procedure for the protection of their membership against the solicitation of legal business. Legislatures in many of the States have made the solicitation of legal business a criminal offense. It is obvious, however, that a committce on ethics of a bar association, or even a prosecuting State officer charged with the duty of prosecuting persons for the violation of statutes prohibiting the solicitation of legal business, cannot effectively prevent lawyers in distant States from violating codes of ethics, or State statutes, designed to prevent the solicitation of such business. Solicitation by the very nature of its practice is done in secret, and the solicitor is usually safely within his own jurisdiction before his actions are discovered. Therefore, as a practical matter, such canons of ethics of bar associations or State statutes designed to prevent such solicitation are totally inadequate to protect those affected by the evils of the solicitation of legal business." Hearings Before Subcommittee No. 4 of the House Committee on the Judiciary on H. R. 1639 , 8oth Cong., Ist Sess. 128 (1947).

The House Committee on the Judiciary thought that these disbarment actions and injunction proccedings afforded inadequate remedies: "Disbarment proceedings have been filed against various attorneys who have degraded their profession by the solicitation of personal injury suits against railroads, and injunction proceedings have been instituted against other attorneys to prevent their further prosecution of pending cases. Many attorneys have been censured, some have been disbarred, and others have been ordered to return fees which they have collected. While such actions are of some effect, the committee believes that only through the legislative process can lasting relief from these vicious practices be obtained." Venue in Actions Against Interstate Carriers by Railrond on Account of Death or Personal Injuries, House Rep. No. 613, 8oth Cong., ist Sess. 5 (1947).

${ }_{103}$ Ackerman v. State, 124 Tex. Crim. Rep. 125, 6I S. W. 2d II6 (I933) (lawyer convicted of barratry); Laird v. State, 242 S. W. 2 d 374 (Tex. Crim. App. I95I) (layman convicted of barratry); People v. Levy, 8 Cal. App. 2d 763, 50 P. 2d 509 (I935) (layman convicted of barratry); People v. Meola, 193 App. Div. 487, I84 N. Y. Supp. 353 (2d Dep't r920) (layman convicted of barratry); State v. Batson, 220 N. C. $4 \mathrm{II}$, I7 S. E. $2 \mathrm{~d} 5 \mathrm{Ir}$ (194I) (layman convicted of attempt to commit barratry); Ex parte MoCloskey, 82 Tex. Crim. Rep. 53r, I99 S. W. 2 d I IoI (r917), affirmed, McCloskey v. Tobin, 252 U. S. ro7 (r920). McCloskey was a layman who was arrested for barratry involving solicitation activities; it was held that the statute under which he was arrested was constitu' tional. 
claims to be sued upon where the attorney resides. Too often the law enforcing authorities in none of the states involved are disposed to go to the trouble of investigating a practice of this kind. Those at the place of residence of the ambulance chaser are much more concerned where the solicitation takes place on the local scene and are inclined to leave it to someone else to take action against solicitation that occurs elsewhere. Authorities in the foreign states are inclined to disregard solicitation for the benefit of an attorney located elsewhere who is not amenable to process in the state and whose runners, constantly moving from place to place, are more than ordinarily difficult to apprehend. The result is that what is everybody's business is too frequently nobody's business. Yet unscrupulous lawyers in the big cities continue to send their runners out into distant states to solicit claims to be sued on at their headquarters.

\section{Stemming the Tide of Imported Lawsuits-Remedies for Abuse of Venue}

The other remedies that have been attempted have all had the common problem of preventing an abuse of the broad and wide-open venue provided by the FELA. There is nothing new about abuses of venue. At early common law all actions were local and could be tried only in the county in which the action arose. Later when juries ceased to be witnesses and became impartial triers of the evidence introduced before them, transitory actions could be brought in any county where the defendant could be served. ${ }^{104}$ But this loose venue provision was susceptible of abuse and like the latter day venue clause of the FELA it was misused. To curb the evil, statutes were passed beginning in 1382 , when by the Act of 6 Richard II, chapter 2, it was enacted that venue in the transitory actions of "debt and accompt, and of other such actions" should be laid in the county where the cause of action arose. Even in cases not within the statute the defendant, save in exceptional circumstances, could insist upon removal of the case to the county where it arose. The only exception to this general rule was that the court was vested with discretion to refuse such a change of venue in order to prevent injustice. In the Act of 4 Henry IV, chapter I8, passed to correct "sundry damages and mischiefs" caused by attorneys, it was provided that attorneys should be examined by the justices, and if found to be qualified should be "received and sworn well and truly to serve in their offices, and especially that they make no suit in a foreign county."105

Today, notwithstanding the general rule that a transitory action may be brought where the defendant may be served, the rule is subject to many qualifications. There may be a change of venue for one reason or another. One ground for change of venue recognized by many statutes is the convenience of witnesses and the promotion of the ends of justice. ${ }^{106}$

I04 56 AM. JUR. VENUE $\$ 3$.

$1053 \mathrm{Br}$. COMM. c. 20, $\$ 37 \mathrm{I}$; Pound, Readings on the History and System of the Common Law I48-149 (3d ed. i947); Gilbert, The History and Practice of Civiz Actions 89 (i76i); Tidd, Tiue Practice of the Courts of King's Bench and Common Pleas 6or (4th American ed. i856).

${ }^{100} 56$ AM. JUR. Venue $\$ 58$; Gulf Oil Corp. v. Gilbert, 330 U. S. 501, 507 (1947); Mooney v. Denver \& R. G. W. R. R., 221 P. 2 d 628 (Utah 1950). 
Other qualifications have arisen out of recognition that the general rule applicable to transitory actions was originally formulated when the defendant was an individual who could ordinarily be found only at his home or at his place of business. When private corporations first came upon the scene they were more often than not small or confined to localized operations. In this country the advent of large corporations, including railroads and other carriers, often carrying on some kind of activity at places thousands of miles apart, gave rise to a distinctly different problem which is sometimes recognized by statutes ${ }^{107}$ which restrict the venue in personal injury suits against carriers. The Federal Tort Claims Act of $1946,^{108}$ in authorizing suits for tort against the United States, provides for venue "only in the district wherein the plaintiff is resident or wherein the act or omission complained of occurred." In this modern venue statute Congress wisely steered clear of any such extraordinarily broad venue provisions as those contained in the present FELA and instead deliberately adopted for application in tort litigation against the United States substantially the same rule as the one applied by the federal government in General Orders I8 and I8a during federal control of railroads in World War I.

In suits under the FELA three well-defined remedies have been invoked for the control of abuses of venue. They are: (I) the doctrine of forum non conveniens; (2) the rule barring suits producing an unusual burden on interstate commerce; and (3) the equitable rule granting relief against vexatious and oppressive litigation. All three are founded in some measure on considerations affecting the convenience of parties and witnesses as indeed is every principle of the law of venue.

The transportation of a personal injury claim for suit at a distant point may, depending upon circumstances, cause anything from a slight or moderate inconvenience to gross inconvenience amounting to hardship and oppression. There is inconvenience and expense in transporting witnesses from their residence to the place of trial. Witnesses who reside in one state cannot be compelled to go to another state to testify. Their attendance can be obtained if at all by meeting their terms as to compensation and expense allowances, sometimes entailing a very considerable outlay. Physicians, surgeons, medical technicians, and nurses with evidence regarding the extent of injuries or other medical questions often cannot conveniently leave their regular occupations to go to a trial at a distant place. It is likewise sometimes inconvenient for regular employees of a railroad company to spend the added time required by such a trip. In the manpower shortages of World War I and World War II this requirement resulted in very substantial hardship. Depositions are usually a poor substitute for the oral testimony of a witness. Where the trial takes place away from the scene of the accident a view of the premises by a jury becomes impossible. Trial at a distant place increases the disadvantages of a party confronted with surprise contentions or testimony because witnesses are difficult to obtain on short notice during the course of the trial. These things

107 Ohio Code Ann. $\S$ II273 (I936); N. C. Gen. Stat. ANn. §I-83 (I943); Ga. Code Ann. \$94-IIoI (1936); Ky. Codes, Civ. Prac. \$73 (I938); Tex Stat., Rev. Civ. art. I995-25 (I925).

${ }_{208}^{28}$ U. S. C. $\$ \mathrm{I}_{404}(\mathrm{~b})$. 
combine to bring pressure on a defendant to yield to extraordinary demands, to pay excessive amounts in settlement of false or exaggerated claims where suit is filed at a remote place. ${ }^{100}$

In addition to these private inconveniences and hardships there are public ones as well, attendant upon the burden on the courts and the taxpayers of the metropolitan centers to which these personal injury cases are imported for trial. The courts and juries at the place of trial, perhaps overburdened with domestic litigation, are forced to assume the burden of adjudicating law suits imported from remote parts of the country. The taxpayer there is forced to defray out of his pocket the cost of carrying this load of foreign litigation.

The dockets of the trial courts in the large cities are congested and the courts are many months, and in some cases several years, behind in the trial of tort cases. Thus in New York City the state supreme court is three years behind. ${ }^{110}$ In the

${ }^{100}$ One of the best statements of the elements of inconvenience in a personal injury suit tried away from its normal situs is contained in the complaint filed in Union Pacific R. R. v. Thatcher, 173 Ore. 572, 146 P. 2d 76 (1944), cert. denied, 323 U. S. 710, which is not set forth in the report of the case but which was quoted with approval by the House Judiciary Committee in House Rep. No. 613, 8oth Cong., rst Sess. 5-6 (1947):

"Said practice deprives the defendant railroad of all reasonable opportunity to defend itself on the factual issues in such cases because of its inability, except at grossly excessive cost and with serious interference with its transportation operations, to obtain the attendance of witnesses whose oral testimony is essential to an adequate and understandable presentation of the facts on which such claims are based. In all such cases, liability of the defendant carrier depends upon whether it was or was not negligent in certain of its railroad operations; and ordinarily such operations cannot be made intelligible to the juror except by oral explanation (and frequently with the aid of maps, models, or other exhibits) by those who actually operate or work about the particular instrumentalities involved. Usually such explanations cannot be made adequately or understandably by witnesses testifying by deposition only; and because of the inability of jurors to determine intelligently the credibility of such unseen witnesses, or the probative value of their testimony, such evidence is disregarded or given seant consideration even though it would have been given full weight had it been presented orally in the presence of the jury.

"As witnesses who reside in one State cannot be compelled to testify in the courts of another State, their attendance can be obtained only by meeting their own terms of compensation and expense allowances; and the cost of procuring their personal attendance in a foreign State may be and frequently is excessive, burdensome, and out of all proportion to the actual value of the claim in litigation.

"Said practice prevents a view by the jury of the premises, facilities, or instrumentalities involved and thereby encourages and facilitates confusion, distortion, and misrepresentation of the pertinent physical facts. Such confusion operates to the advantage of a plaintiff asserting a claim of doubtful merit.

"Such practice enables the claimant in such a case to take the defendant by surprise by offering testimony and making factual contentions which such defendant may have no reason to anticipate and which it cannot meet because of its inability to obtain witnesses on short notice and from far-distant places during the course of the trial.

"Because of the inability of the defending railroads to defend themselves against such forcign suits, the said scheme of said attorneys enables claimants to obtain findings of liability against the defendant carrier in cases wherein no such liability existed in fact, and to obtain grossly excessive awards of damages in cases wherein no substantial damage was actually sustained by the claimant.

"Such practice enables the claimants to exact from such railroads grossly excessive amounts in settlcment of false or exaggerated claims because of the desire of such railroads to avoid the burdensome cost, interruption of business, and unsatisfactory results of litigating such claims in a forcign jurisdiction under the circumstances above described."

${ }^{120}$ The New York Law Journal, Nov. I8, 1952, shows by the Ready Numbered Calendar of the supreme court trial term, that the cases reached in regular order for trial are those at issue in November 1949-three years previousily. In the New York Times, Vol. CII, I, Nov. 24, 1952, it is stated that the jury trial docket of personal injury cases of the supreme court is more than three years behind, and that a 
United States district court for the southern district of New York the civil jury calendar is thirty-five months behind ${ }^{111}$ - a condition for which an influx of FELA cases is partly to blame. In Chicago, if all of the cases now on the docket in the state courts were to go to trial and no new cases are added, it would take about three years to free the courts of their present congestion. ${ }^{112}$ The federal court in Chicago is about sixteen months behind in the trial of jury cases. ${ }^{113}$

\section{Forum Non Conveniens}

The doctrine of forum non conveniens invokes the right of a court to decline to entertain a suit where for the convenience of parties and witnesses and in the interests of justice it should be tried elsewhere. While there is some difference of opinion about how long this principle has been established in English and American jurisprudence, it has been recognized in a number of jurisdictions. ${ }^{114}$ The essence of forum non conveniens is that a court may resist taking cognizance of a suit even

plan to expedite the disposition of cases has been adopted by the court under which a panel of medical experts has been formed to examine plaintiff and report to the judge and to attorneys on both sides in cases where there is a wide difference in medical claims.

1x1 "The Southern District of New York continues to be further in arrears than any other district. The number of civil cases filed in 1952 was 5,453, compared with 4,946 last year. This was $34 \mathrm{I}$ new civil cases per judge compared with the national average of 236 . Cases terminated were 280 less than those commenced with the result that the pending caseload rose to $x x, 428$. This is a new peak and is a continuation of a steady climb since the end of 1943 when the figure was 3,493 . The number of private cases pending has also more than tripled since that time and as of June 30,2952 , stood at 8,960. This district with 16 judges has more than one-fifth of the civil cases pending in all 86 districts having purely federal jurisdiction, for which there is a total of 202 judgeships. The calendar commissioner's estimate of the time now required to reach a case after joinder of issue is 35 months for jury cases, 26 months for non-jury, and 27 months for admiralty. The Administrative Office figures indicate that the median interval from filing to disposition for 258 civil cases terminated after trial in 1952 was 41.2 months while the interval from issue to trial was 33.1 months. The type of cases in this district must also be taken into account in considering the caseload. More than half of all admiralty, copyright and Jones Act cases pending in the courts of the 86 districts are in the Southern District of New York, almost one-third of all private civil cases and close to one-fifth of all Employers' Liability Act cases, patent cases and government antitrust suits. The Judicial Conference has recommended 3 permanent and 2 temporary judgeships for this district and the conditions above described indicate the urgent need for this legislation." ANNUAL REPORT OF THE DiRECTOR OF THE ADMINISTRATIVE OFFICE OF THE UNITED STATES COURTS I04-I05 (1952).

${ }^{112}$ Comment, Settlement of Personal Injury Cases in the Chicago Area, 47 NORTHWESTERN U. I. REv. 895,896 (1953). See also, Life, November I0, 1952, p. 127.

113 "The Northern District of Illinois. An increase of more than 28 per cent in the number of civil cases filed put the dockets in this district further behind in 1952 . Civil cases filed were 2,567 and terminations were 2,127 , lifting the pending caseload to 2,661 or more than twice the r94I figure. Nevertheless more civil cases were tried than in any previous year and the median interval from filing to disposition went down from 16.7 months in 1951 to 15.8 in 1952 . The median from issue to trial decreased also from I0.8 months to I0.3. Vacancies have existed for two years in the two judgeships created by the Act of August 14, I950, (64 STrr. 443) and these positions are still unfilled." Annual Report of the Director of the Administrative Office of the United States Counts ro6-ro7 (1952).

${ }^{114}$ Canada Malting Co. v. Patterson Co., 285 U. S. 4I3, 422 (1932); Gulf Oil Corporation v. Gilbert, 330 U. S. $50 I$ (I947); Rogers v. Guaranty Trust Co., 288 U. S. I23 (1933); Wedermann v. U. S. Trust Co. of New York, 258 N. Y. 315, I79 N. E. 712 (1932); Foster, Place of Trial in Civil Actions, 43 HARv. L. REv. I2I7 (x930); Blair, The Doctrine of Forum Non Conveniens in Anglo-American Law, 29 Cor. L. REv. I (I929); Barrett, The Doctrine of Forum Non Conveniens, 35 CaIr. L. REv. 380 (r947); Dainow, The Inappropriate Forum, 29 Ind. L. Rev. 867, 889 (I935). 
when jurisdiction is authorized by the letter of the venue statute. ${ }^{115}$ In the application of the doctrine the familiar considerations relating to the convenience of parties and witnesses are taken into account. ${ }^{116}$ Factors of public, as well as of private, interest enter into the ultimate determination. ${ }^{117}$

This principle has been applied in New York in cases arising under the FELA brought in courts of the state. In Murnan $v$. Wabash $R . R_{0}^{118}$ an action was begun in a state court of New York by a Connecticut plaintiff based on a claim under the Act for an accident which occurred in Michigan on the defendant's railroad. The trial court applied the principle of forum non conveniens to dismiss the case. The Appellate Division reversed and certified to the Court of Appeals the question of law whether the courts of the state are invested with discretion to decline jurisdiction of such an action. The Court of Appeals answered the question in the affirmative, holding Congress did not intend that a plaintiff in a case under the FELA should stand in a different position from any other nonresident litigant suing on a foreign cause of action. ${ }^{119}$

115 "The principle of forum non conveniens is simply that a court may resist imposition upon its jurisdiction even when jurisdiction is authorized by the letter of a general venue statute. These statutes are drawn with a necessary generality and usually give a plaintiff a choice of courts, so that he may be quite sure of some place in which to pursue his remedy. But the open door may admit those who seek not simply justice but perhaps justice blended with some harassment. A plaintiff sometimes is under temptation to resort to a strategy of forcing the trial at a most inconvenient place for an adversary, even at some inconvenience to himself.

"Many of the states have met misuse of venue by investing courts with a discretion to change the place of trial on various grounds, such as the convenience of witnesses and the ends of justice. The federal law contains no such express criteria to guide the district court in execising its powcr. But the problem is a very old one affecting the administration of the courts as well as the rights of litigants, and both in England and in this country the common law worked out techniques and criteria for dealing with it." Gulf Oil Corp. v. Gilbert, 330 U. S. 501, 507 (1947).

116 "Wisely, it has not been attempted to catalogue the circumstances which will justify or require either grant or denial of remedy. The doctrine leaves much to the discretion of the court to which plaintiff resorts, and experience has not shown a judicial tendency to renounce one's own jurisdiction so strong as to result in many abuses.

"If the combination and weight of factors requisite to given results are difficult to forecast or state, those to be considered are not difficult to name. An interest to be considered, and the one likely to be most pressed, is the private interest of the litigant. Important considerations are the relative case of access to sources of proof; availability of compulsory process for attendance of unwilling, and the cost of obtaining attendance of willing, witnesses; possibility of view of premises, if view would be appro priate to the action; and all other practical problems that make trial of a case easy, expeditious and inexpensive. There may also be questions as to the enforcibility of a judgment if one is obtained. The court will weight relative advantages and obstacles to fair trial. It is often said that the plaintiff may not, by choice of an inconvenient forum, 'vex,' 'harass,' or 'oppress' the defendant by inflicting upon him expense or trouble not necessary to his own right to pursue his remedy. But unless the balance is strongly in favor of the defendant, the plaintiff's choice of forum should rarely be disturbed." $1 d$. at 508.

${ }_{127}$ "Factors of public interest also have place in applying the doctrine. Administrative difficultics follow for courts when litigation is piled up in congested centers instead of being handled at its origin. Jury duty is a burden that ought not to be imposed upon the people of a community which has no relation to the litigation. In cases which touch the affairs of many persons, there is reason for holding the trial in their view and reach rather than in remote parts of the country where they can learn of it by report only. There is a local interest in having localized controversies decided at home. There is an appropriateness, too, in having the trial of a diversity case in a forum that is at home with the state law that must govern the case, rather than having a court in some other forum untangle problems in conflict of laws, and in law foreign to itself." $I d$. at 508-509.

${ }^{118} 246$ N. Y. 244 , I58 N. E. 508 (I927).

210 "That Congress has undertaken to regulate the exercise of jurisdiction by our courts by making 
A subsequent case of the same nature went to the Supreme Court of the United States. In Douglas v. New York, N.H. \& H. R. R., ${ }^{120}$ plaintiff, a resident of Connecticut, was injured in that state by defendant, a Connecticut corporation. He brought suit under the Act in a state court in New York where defendant was doing business. The trial court applied the principle of forum non conveniens to dismiss the action, and the two New York courts of review affirmed the dismissal. ${ }^{121}$ On certiorari the Supreme Court affirmed the action of the New York courts, holding that there is nothing in the FELA that purports to force a duty upon a state court to entertain jurisdiction in a suit brought under the Act, against an otherwise valid excuse. ${ }^{122}$

But before the enactment of Section I404(a) of the Judicial Code, the federal courts refused to recognize any corresponding principle in suits before them. In Southern $R y$. v. Cochran ${ }^{123}$ the railway company filed with the circuit court of appeals an original petition for a writ of prohibition to restrain a district court in Kentucky from trying a suit brought against the company by one of its employees, a resident of South Carolina, who had been injured there. It was contended that a trial in Kentucky would be vexatious and burdensome to the defendant. The circuit court, in denying the writ, distinguished between the power of the federal and of the state courts under the FELA, ${ }^{124}$ stating that where jurisdiction existed the federal courts were under a duty but the state courts were merely granted a power.

\section{Burden on Interstate Commerce}

One of the principal defenses in resisting the long range transportation of claims formerly was that they constituted a burden on interstate commerce and hence could not be permitted consistently with the commerce clause of the federal Constitution. ${ }^{125}$

compulsory what in other similar cases is discretionary seems an unreasonable conclusion and a resulting invasion of the powers of our tribunals as heretofore exercised. We conclude that a litigant who brings his action under the the Federal Employers' Iiability Act stands before the court in no different attitude than a litigant who brings his action under the statute of a sister state. He may not be cast out because he is suing under the act of Congress. He may not enforce his rights merely because he is suing under the act." Murnan v. Wabash R. R., 246 N. Y. at 248 , 158 N. E. at 509.

${ }^{120} 279$ U. S. 377 (1929).

121223 App. Div. 782,227 N. Y. S. 797 (2d Dep't), 248 N. Y. 580,162 N. E. 532 (1928).

132 "As to the grant of jurisdiction in the Employers' Liability Act, that statute does not purport to require State Courts to entertain suits arising under it, but only to empower them to do so, so far as the authority of the United States is concerned. It may very well be that if the Supreme Court of New York were given no discretion, being otherwise competent, it would be subject to a duty. But there is nothing in the Act of Congress that purports to force a duty upon such Courts as against an otherwise valid excuse." Douglas v. New York, N. H. \& H. R. R., supra note I20, at 387-388.

${ }^{123} 56$ F. 2d 1019, 1020 (6th Cir. r932).

124 "Concluding that jurisdiction to try the case exists, has the defendant any discretion to refuse to exercise it? We think not. The existence of jurisdiction, when otherwise adequate to the occasion, creates an implication to exercise it. Second Employers' Liability Cases, 223 U. S. I, 32 S. Ct. I69, 56 L. Ed. 327,38 L. R. A. (N.S.) 44. Authorities holding that state courts may by reason of local law under like circumstances in their discretion refuse to entertain a suit under the act, are not controlling, for the statute does not impose a duty upon state courts as against a valid excuse, but rather confers a power." Id. at 1020 .

${ }_{125}$ The question presented to the court, although not the same, is akin to the objection under the due process clause to a suit against a defendant in a state where he is not doing business. A railway company engaged solely in soliciting business within the state may not be sued there consistently with 
The individual railroad, especially one of the larger systems, may carry on activities of one kind or another throughout the length and breadth of the United States. Some of them operate lines of railroad in numerous districts and in many states. The Chicago, Milwaukee, St. Paul and Pacific Railway Company, for instance, has a line extending from Chicago to Seattle. The Atchison, Topeka and Santa Fe Railway runs from Chicago to Los Angeles, San Francisco, and San Diego. The Southern Pacific System operates from San Francisco to New Orleans, while the Southern Railway runs between Washington and New Orleans. The Pennsylvania, New York Central, and Baltimore and Ohio Railroads have ramified operations between New York, Chicago, and St. Louis. Many of the carriers solicit freight and passenger business in the principal cities of the country outside of the territory in which they operate. Quite a few of the larger companies maintain financial offices in New York.

To transport a personal injury claim for suit five hundred or one, two or three thousand miles from its normal situs where the cause of action arose or where the plaintiff and the witnesses have their residences is not only costly but may be disruptive of operations. It inflicts a burden not only on the company and the owners of its stocks or bonds, but also on the shipping and traveling public who, in the last analysis, must pay for the service they use enough to meet the expenses of carrying on the business. The drain imposed by a single trial at a remote place may not be of great consequence, but when trials of this sort multiply and when settlements at excessive figures are constantly being forced to avoid the undue expense of such trials, then the economic waste and the load on the business may assume serious proportions and may become a burden on interstate commerce in a very real sense.

This was recognized by the Supreme Court in a case from Minnesota already noted, Davis v. Farmers Co-operative $\mathrm{Co}^{126}$ brought soon after the railroads had been returned to private ownership after World War I. A Minnesota statute of I9I3 allowed suit against any foreign corporation having an agent there for the solicitation of freight or passenger traffic over its lines outside of the state. Action was brought in a state court for damages for loss of grain shipped between two points in Kansas. The transaction was in no way connected with Minnesota or with the soliciting agent located there. The Court held the statute obnoxious to the commerce clause, imposing a serious and unreasonable burden. It adverted to the finding of the Director General of Railroads during World War I that absences of employees incident to litigation at remote places substantially interfered with operation of the railroads, stating that the grounds recited by the Director General in General Orders 18 and 18 a were of general application in times of peace as well as of

the requirements of the due process clause of the Fourteenth Amendment. Green v. Chicago, Burlington, \& Quincy Ry., 205 U. S. 530 (1907). Annotations: 46 A. L. R. 570, 583, 95 A. L. R. I478. If, however, in addition to soliciting traffic a company is also engaged in some form of strictly local business although not in running trains it is subject to suit. St. Louis S. W. Ry. v. Alexander, 227 U. S. 218 (1913).

${ }_{226}^{262}$ U. S. 312 (I923). 
war. ${ }^{127}$ The Court was strongly impressed with the economic wastefulness of, and the lack of any reasonable basis for, subjecting a carrier to suit in a state having no connection with the transaction. ${ }^{128}$

While Davis v. Farmers Co-operative Co. related to loss and damage to freight, other cases soon came along applying the same rule to actions for personal injuries under the FELA. In Atchison, T. \& S. F. Ry. v. Wells, ${ }^{129}$ an employee injured in New Mexico where he lived sued in a state court in Texas where the defendant was not'doing business and had no line of railroad. He obtained service by garnishing under a state statute certain rolling stock and traffic balances belonging to the defendant, serving notice on one of its officers in Kansas and by publication in a Texas newspaper. The defendant did not appear and judgments were entered by default. The carrier brought suit in a federal district court to enjoin the enforcement of the judgments. The Supreme Court held that the personal injury suit necessarily and unreasonably burdened interstate commerce and that the judgments were void. ${ }^{130}$ In Weinard $v$. Chicago, $M . \& S t . P . R y_{.}^{130^{2}}$ the court enjoined as a burden on interstate commerce a suit in a federal district court in a state where the defendant railroad was running trains. Plaintiff had sustained an injury while in the employ

${ }^{197}$ The Court (Brandeis, J.) said (p. 356): "During federal control absences of employees incident to such litigation were found, by the Director General, to interfere so much with the physical operation of the railroads, that he issued General Order No. I8 (and I8A) which required suit to be brought in the county or district where the cause of action arose or where the plaintiff resided at the time it accrued. That order was held reasonable and valid in Alabama \& Vicksburg Ry. Co. v. Journey, 257 U. S. III. The facts recited in the order, to justify its issue, are of general application, in time of peace as well as of war."

${ }^{128}$ The Court held (pp. $316-317$ ): "It may be that a statute like that here assailed would be valid although applied to suits in which the cause of action arose elsewhere, if the transaction out of which it arose had been entered upon within the State, or if the plaintiff was, when it arose, a resident of the State. These questions are not before us; and we express no opinion upon them. But orderly, effective administration of justice clearly does not require that a foreign carrier shall submit to a suit in a State in which the cause of action did not arise, in which the transaction giving rise to it was not entered upon, in which the carrier neither owns nor operates a railroad, and in which the plaintiff does not reside. The public and the carriers are alike interested in maintaining adequate, uninterrupted transportation service at reasonable cost. This common interest is emphasized by Transportation Act, 1920, which authorizes rate increases necessary to insure to carriers efficiently operated a fair return on property devoted to the public use. See Railroad Commission of Wisconsin v. Chicago, Burlington \& Quincy R. R., Co., 257 U. S. 563; New England Divisions Case, 26I U. S. 184. Avoidance of waste, in interstate transportation, as well as maintenance of service, has become a direct concern of the public. With these ends the Minnesota statute, as here applied, unduly interferes. By requiring from interstate carriers general submission to suit, it unreasonably obstructs, and unduly burdens, interstate commerce."

${ }_{120}^{265}$ U. S. IOI (1924).

${ }^{200}$ The Court (Brandeis, f.) held (p. ro3), "But the writ of garnishment is void because of the purpose for which it was invoked. The Santa Fe is a Kansas corporation. It had not been admitted to Texas as a foreign corporation. It had not consented to be sued there. It did not own or operate any line of railroad within the State; and had no agent there. The Texas statutes concerning garnishment were construed and applied in the Wells suit so as to permit a citizen and resident of another State to prosecute in Texas a cause of action which arose elsewhere against a railroad Corporation of another state, which is engaged in interstate commerce, which neither owns nor operates a railroad in Texas, and which has not consented to be sued there. For the reasons stated in Davis v. Farmers Co-operative Co., 262 U. S. 3 I2 (decided since the entry of the judgment here under review) such a suit necessarily and unreasonably burdens interstate commerce; and the statute as construed and applied is invalid."

${ }_{1302} 298$ Fed. 977 (D. Minn. I924). 
of the railroad in Tacoma, Washington, and had brought suit in Minneapolis, Minnesota, $I 787$ miles distant from the place of injury.

In Michigan Central R. R. v. Mix, ${ }^{131}$ a switchman living in Michigan was killed in that state in the performance of his duties. After his death his widow moved to Missouri where she was appointed administratrix and brought an action for damages in a state court. The defendant had no line of railroad in Missouri, had not consented to be sued there, and had never done any business there except for the solicitation of traffic. The Supreme Court held that the mere fact of the acquisition of a residence within Missouri by the administratrix did not justify the heavy burden on interstate commerce which would be entailed in trying the case in a state remote from that in which the accident occurred and in which both parties resided at the time.

Relief on the ground of burden on interstate commerce was denied, however, whenever the defendant had a line of railroad in the state of the forum.

In Hoffman v. Foraker, ${ }^{132}$ suit was brought in a state court in Missouri under the FELA by a citizen and resident of Kansas for the death of an employee of the Missouri Pacific Railroad. The accident occurred on its line in Kansas and the deceased was a citizen of Kansas at the time of his death. The railroad is a Missouri corporation and the action was brought in a county traversed by its line. The railroad contended that there were at least eleven employees working for it in Kansas who were necessary witnesses, and that to procure their attendance at the trial in Missouri would be burdensome and expensive. The Court refused to interfere with the maintenance of the action, holding that any incidental burden to interstate commerce must be subordinated to the requirements of orderly, effective administration of justice. ${ }^{133}$

In Denver \& R. G.W.R.R. v. Terte, ${ }^{134}$ the Court gave relief to a defendant engaged merely in solicitation of traffic in the state of the forum but refused it to a joint defendant, another carrier, which conducted physical operations in the county and the state of the forum. A joint employee of the Santa Fe Railway and the Denver \& Rio Grande Western Railroad was injured at work in Pueblo, Colorado where he lived. He moved to Missouri and became a bona fide resident and citizen there and thereafter brought suit in a state court in Kansas City against both companies. It appeared that the trial would require the attendance of some wit-

${ }^{131} 278$ U. S. 492 (1929).

${ }^{130} 274$ U. S. 21 (I927).

${ }^{133}$ The Court (Brandeis, J.) said (pp. 22-23): "These allegations remind of Davis v. Farmers Co-operative Co. But other facts on which the decision of that casc was rested are absent in the case at bar. Here, the railroad is not a foreign corporation; it is sued in the State of its incorporation. It is sued in a State in which it owns and operates a railroad. It is sued in a county in which it has an agent and a usual place of business. It is sued in a State in which it carries on doubtless intrastate as well as interstate business. Even a foreign corporation is not immune from the ordinary processes of the courts of a State where its business is entirely interstate in character. International Harvester Co. v. Kentucky, 234 U. S. 579. It must submit, if there is jurisdiction, to the requirements of orderly, effective administration of justice, although thereby interstate commerce is incidentally burdened. Compare Kane v. New Jersey, 242 U. S. 160, 167; St. Louis, Brownsville \& Mexico Ry. v. Taylor, 266 U. S. 200."

${ }_{184} 284$ U. S. 284 (1932). 
nesses for the plaintiff who resided in Missouri and of some witnesses for the defendants from Colorado who would have to be brought to Missouri at large expense. The Santa Fe operated a line in Missouri, Colorado, and other states. The Rio Grande had no line in Missouri but owned and used some property there and maintained one or more offices in the state employing agents who solicited traffic. The Court held that the suit was properly maintainable against the Santa Fe but not against the Rio Grande. ${ }^{135}$ Following the general principles of these decisions the right to maintain a suit under the FELA has been denied as an undue burden on interstate commerce in a number of instances, ${ }^{136}$ while in other cases this defense has been held to be unavailable. ${ }^{137}$

In none of these cases did the Court give any detailed attention to the special venue clause of the FELA. Apparently it treated the clause on the same footing as the state laws with respect to jurisdiction and venue-regarding all of them as ordinary procedural rules of a general nature which would have to yield in event of conflict with the constitutional ban against burdens on interstate commerce. These suits were without exception brought in state courts and where a burden on interstate commerce appeared the court was considered as thereby deprived of jurisdiction so that any judgment that it might enter was void and its enforcement subject to injunction as in the Wells case.

${ }^{135}$ The Court (McReynolds, J.) said (pp. 287-288): "Under the rule approved in Michigan Central R. Co. v. Mix, 278 U. S. 492 , the Rio Grande properly claimed exemption from suit in Jackson County. It was not necessary to join the two Railroad Companies in one action. Whatever liability exists is several. The prohibition against burdening interstate commerce cannot be avoided by the simple device of a joint action. Nor can this be evaded merely by attaching the property of the non-resident railroad corporation. Obviously, the burden and expense which the carrier must incur in order to make defense in a State where the accident did not occur has no relation to the nature of the process used to bring it before the court.

"The alleged residence in Missouri of persons whose testimony plaintiff supposed would be necessary to prove his claim was not enough to justify retention of jurisdiction by the Circuit Court. While this circumstance might enable plaintiff to try his cause there with less inconvenience than elsewhere, it would not prevent imposition of a serious burden upon interstate commerce. And, we have held, it is the infliction of this burden that deprives the courts of jurisdiction over cases like this. Davis v. Farmers Co-operative Co., 262 U. S. 312. Further, as a practical matter, courts could not undertake to ascertain in advance of trial the number and importance of probable witnesses within and without the State and retain or refuse jurisdiction according to the relative inconvenience of the parties."

${ }^{136}$ Ex parte Crandall, 53 F. 2d 969 (7th Cir. r93I), affirming, 52 F. 3d 650, cert. denied, 285 U. S. 540 (I93I); Kern v. Cleveland, C. C. \& St. L. R. R., 204 Ind. 595, I85 N. E. 446 (I933); Cleveland C. C. \& St. L. R. R. v. Shelly, 96 Ind. App. 273 , 170 N. E. 328 (1930), 104 A. L. R. 1083.

${ }_{137}$ Mobile \& O. R. R. v. Parrent, 260 Ill. App. 284 (1930); Peterson v. Chicago, B. \& Q. R. R., I87 Minn. 288, 244 N. W. 823 (r932); Wolfe v. Chicago, M. St. P. \& P. R. R., r80 Minn. 3ro, 230 N. W. 826 (1930); Erving v. Chicago \& N. W. R. R., I7I Minn. 87, 214 N. W. I2 (1927). In the latter case the court said (I I I Minn. at 94, 24I N. W. at I5): "This claim of interference or burden to interstate commerce must not be exaggerated. Such burden will seldom occur. It can only be accasional and temporary. The ordinary duties of a railroad are quite certain, and provision for them can be easily made. It is given ample time for preparation. We may assume that 2 railroad company is well equipped to properly protect itself in litigation throughout its entire system, and so long as it is not required to go beyond its own territory, i.e., the states reached by its own tracks or rolling stock, to defend in such actions, it should be held that such suits are not an undue burden to commerce. We will not introduce a rule that will unnecessarily force a resident of the state to go to a foreign jurisdiction for justice. ..."

See Annotation, Assumption of jurisdiction by court as violation of commerce clause, $10_{4}$ A. L. R. $1075,1082-1083$ (1936). 
It did not seem to occur to the Supreme Court that the presence or absence of jurisdiction in a state court could be affected by the federal rule of venue found in the FELA. It may be noted, however, that the refusal to allow the suits to proceed in the Wells, Terte, and Mix cases where the defendant was doing nothing more than soliciting traffic was in line with the result that would have been reached in a federal court under the special venue clause of the Act, because the defendant was not incorporated or doing business and the cause of action did not arise in the state of the forum. The same thing was true where the suits were permitted to proceed as in the Foraker and Terte cases because in them the defendant owned and operated a railroad line in the county and state of the forum and since it was also doing business there, would have been subject to suit in the federal court under the venue clause. In another type of situation, however, the doctrine in these cases afforded relief from burdensome litigation where a suit could have been brought under the venue clause in a federal court-where the defendant although doing business in a state owned no trackage and ran no trains there.

The defense of burden on interstate commerce has been raised in numerous cases not involving the FELA. It was held not to apply in a suit by a resident of the state of the forum against a railroad for negligence resulting in the loss of goods consigned to him there, on the ground that the negligence might have taken place within the state, even though the defendant maintained no office in the state and suit against it was based upon the garnishment of traffic balances due it from local roads. ${ }^{138}$ But an unreasonable burden was held to be imposed by an action by a plaintiff, who became a resident of the state after the cause of action accrued, against a steamship company which carried on no activities in the state except to keep a bank account and solicit business for commerce which did not touch the state. $^{139}$ The right to maintain a suit against a railroad company doing business although not operating a line of railroad within the state of the forum was denied as a burden on interstate commerce where it was brought by a department of a foreign government to recover for loss of a shipment of freight, where the contract was made and was to be performed wholly outside the state. ${ }^{140}$ The important features in the determination whether there is a burden on interstate commerce by reason of a particular suit are the residence of the parties, the nature of the defendant's business and the place where it is carried on, the place where the contract was made and was to be performed, and the place where the cause of action or the injury occurred. ${ }^{1402}$

${ }^{138}$ Missouri ex rel. St. Louis, B. \&. M. R. R. v. Taylor, 266 U. S. 200, 42 A. L. R. 1232 (1924).

${ }^{189}$ Baltimore Mail Steamship Company v. Fawcett, 269 N. Y. 379,199 N. E. 628, 104 A. L. R. 1068 (1936).

140 Panstwowe Zaklady Graviozne v. Automobile Ins. Co., 36 F. $2 d$ 504 (S. D. N. Y. 1928). The court said (p. 506): ". . an application of the statute subjecting the defendant to the necessity of defending such claims in the courts of New York would impose upon its conduct of interstate commerce unreasonable burdens. . . . The fact that the defendant railroad company is engaged in business in the state, and by doing business here has consented to be sued here, is no basis for the assertion of jurisdiction of actions by nonresidents which arise in other states and which are entirely disconnected with the business it does here."

${ }^{1402}$ Annotation, Assumption of jurisdiction by court as violation of commerce clause, 104 A. L. R. 1075, 1076 (1936). 
Injunction Against Maintenance of Suit in Remote Jurisdiction

One of the firmly established grounds of equitable relief by injunction is to restrain the prosecution of vexatious or oppressive lawsuits. Where a party is within the jurisdiction of a court of equity he may be enjoined from prosecuting such an action in a court of another jurisdiction. The principle had been well established before the passage of the FELA, ${ }^{141}$ and it was inevitable when, following the special venue amendment of IgIo claims began to be carried from the state where the cause of action arose to distant places for suit, that relief should be sought on this ground.

One of the first reported cases is one that has already been noticed in connection with the role of solicitation in bringing about the transportation of claims. In Reed's Adm'x v. Illinois Cent. R. R., ${ }^{142}$ long one of the leading cases on the subject, the cause of action had arisen in Kentucky which was the residence of the decedent and the administratrix as well as of all of the witnesses. In asking for an injunction the railway company stated that it would be put to great and unreasonable expense in transporting and defraying the expenses of its witnesses from. Kentucky to Minnesota and would suffer loss and inconvenience from diverting from their ordinary duties for days and perhaps weeks witnesses engaged in train service. It charged that the litigation had been instituted a thousand miles away in Minnesota to harass and annoy it in the conduct of its business, and it relied upon the fact that the suit had been solicited by the attorney for the administratrix as one of the grounds for relief. The court overruled the contention of the administratrix that she could not be restrained by injunctive process from maintaining the action in Minnesota since the railroad company was doing business and was suable there under the terms of the special venue clause. It held that (I) the federal statute did not take away from the courts the power they possessed before its enactment to restrain a plaintiff in a transitory action from doing an inequitable and unconscionable thing, (2) the solicitation of the case by the attorney and the institution of suit in a distant state at his instigation were weighty circumstances to be considered with others in determining whether relief should be granted, and (3) the only purpose of bringing suit in Minnesota was to harass and annoy the company by subjecting it to as much expense and inconvenience as possible. The court therefore upheld the injunction granted below.

In another case, where a railroad employee was a resident of Indiana and met his death in Tennessee, his administratrix was enjoined from bringing an action against the employer in a state court in Missouri on the grounds that the prosecution of the action there would improperly, unreasonably, and inequitably burden and harass the company. In Ex parte Crandall ${ }^{143}$ the validity of punishment for contempt for violation of the injunction was upheld, the court taking the view that the

${ }^{141}$ Cole v. Cunningham, I33 U. S. x07 (I890); Dehon v. Foster, 4 Allen 545, 550 (Mass. 186r); Bigelow v. Old Dominion Copper Min. \& Smelting Co., 74 N. J. Eq. 457, 473, 71 Atl. I53 (Ch. 1908).

112 182 Ky. 455, 206 S. W. 794 (1918).

${ }^{143} 53$ F. 2 d 969 (7th Cir. 1931), cert. denied, 285 U. S. 540 (1932). 
special venue clause did not purport to interfere with the powers of a court of equity to grant relief in such circumstances. ${ }^{\mathbf{1 4 4}}$

In Louisville $\& N . R . R . v$. Ragan ${ }^{145}$ plaintiff who was injured in an accident in Nashville where he lived brought suit in an a state court at St. Louis to recover damages. All the witnesses to the accident and certain physicians whose testimony would be required as to the nature and origin of disability lived in Nashville. The court upheld an injunction against the Missouri action on the ground that it was oppressive as well as a burden on interstate commerce.

In other cases, while it was recognized that under appropriate circumstances an injunction would lie to restain the prosecution of an oppressive action in another jurisdiction under the FELA, the facts disclosed were not regarded as sufficient grounds for relief. Thus a suit in a state court in Missouri, about 90 miles from the place in Kansas where the accident occurred, was held not oppressive. ${ }^{140}$ A claim transported from Illinois for suit in a state court in Missouri go miles away was held not to warrant relief. ${ }^{147}$ The same result was reached where a claim was transported for suit in an adjoining state 500 miles from the place of the accident. ${ }^{148}$

The right of a state court in Louisiana to grant an injunction against a suit under the Act in the adjoining state of Texas was denied in Lancaster v. Dunn. ${ }^{140}$ The result turned in part upon the peculiar provisions of the civil code of the state. The court, however, adverting to the allegation that it would be less convenient and more expensive to produce the evidence in the Texas court than it would be in Louisiana, said that if that were a sufficient consideration for forbidding the filing of such a suit elsewhere than at the place where the cause of action arose, the

${ }^{144}$ The court said (p. 97 ) : "The general right of Indiana citizens to begin actions of this nature, wherever service of process on the defendant could be had, was always potentially qualified, by the jurisdiction of equity to restrain the citizen from commencing the action in a foreign jurisdiction where to do so would unreasonably, inequitably, and unfairly harass, oppress, or defraud the defendant. The Federal Employers' Liability Act does not assume to remove this qualification, and, in our judgment, does not exempt the citizen from invocation against him of this equitable jurisdiction under facts which would in general justify its application."

This case was followed in State ex rel. New York, C. \& St. L. R. R. v. Nortoni, 33I Mo. 764, 55 S. W. 2 d 272,85 A. L. R. (I932), upholding the right to an injunction against the transportation of a claim from Indiana for suit in a state court in Missouri. Four Indiana cases are to the same effect: Cleveland C. \& St. L. R. R. v. Shelly, 96 Ind. App. 273, 170 N. E. 328 (1930); Kern v. Cleveland C. \& St. L. R. R., 204 Ind. 595, I85 N. E. 446 (1933); Alspaugh v. New York C. \& St. L. R. R., 98 Ind. App. 280 , I 88 N. E. 869 (1924); and New York C. \& St. L. R. R. v. Perdiue, 97 Ind. App. 174, 87 N. E. 349 (1933).

145 172 Tenn. 593, II3 S. W. 2 d 743 (I938).

${ }^{100}$ Missouri-Kansas-Texas R. R. v. Ball, 126 Kan. 745, 271 Pac. 313 (1928).

${ }^{147}$ Mobile \& Ohio R. R. v. Parrent, 260 Ill. App. 284 (193I).

${ }^{118}$ In Chicago, M. \& St. P. Ry. v. McGinley, I75 Wis. 565, 578, 185 N. W. $218,222-223$ (1921), the court said:

"It cannot be denied that a situation may be presented where the selection of a forum may work hardship or oppression. However, the action was brought in a neighboring statc, and while the distance may be considerable, we cannot say we are satisfied that such selection of a forum on the part of the defendant herein for the trial of his action will work such hardship or oppression as to warrant the intervention of the powers of a court of equity to restrain the further prosecution of such action."

See also to this general effect, Chicago, M. \& St. P. Ry. v. Wolf, I99 Wis. 278, 226 N. W. 297 (x929); Southern Pacific Co. v. Baum, 39 N. M. 22, 38 P. 2d Iro6 (1934).

${ }_{149}$ I53 La. 15,95 So. 385 (1922). 
intention of Congress in enacting the venue clause of the FELA would be frustrated. ${ }^{150}$

While by the weight of authority a state court could, prior to the decisions in Baltimore and Ohio R. R. v. Kepner ${ }^{151}$ and Miles v. Illinois Cent. R. $R^{152}$ restrain a person over whom it had jurisdiction from maintaining an action in a court of another state, ${ }^{153}$ the weight of authority was the other way with respect to its rights to restrain such a person from maintaining suit in a federal court. ${ }^{154}$ The difference in result seems hard to reconcile except on the theory that the state courts are hesitant, because of considerations of comity, to assert the authority to enjoin proceedings in the federal courts. ${ }^{155}$ The difference in result is difficult to explain on any other theory. Both courts, state and federal, had jurisdiction of the subject matter. Neither was required to exercise that jurisdiction against an otherwise valid excuse. The venue in state courts was left by Section 6 of the FELA to be regulated by state law. ${ }^{150}$ Section 6 prescribed the venue in the federal courts, but a review of its legislative history has shown that in enacting it Congress intended to do no more than to lay down an ordinary rule of venue like the similar rules obtaining in the states. If a state venue rule, statutory or otherwise, could not be allowed to stand in the way of an injunction against an inequitable and unconscionable suit, the statutory venue rule found in Section 6 might reasonably be expected also to give way.

The trouble began with Chicago, M. \& St. P. Ry. v. Schendel ${ }^{15 \pi}$ which revolved upon a statute of Iowa, which as construed by the courts of that state proclaimed a public policy against transportation of personal injury claims arising in Iowa for suit outside the state. While the statute, like similar enactments in other states, was passed to check the solicitation of personal injury claims, the Iowa courts held that an injunction should issue even in the absence of proof of solicitationwhich in effect meant that the statute was construed as a prohibition against suing outside of Iowa on a cause of action for personal injury arising in that state. ${ }^{\mathbf{1 5 8}}$

260 "The first is that it would be less convenient and more expensive to produce the evidence in the Texas court than it would be to produce it in the court in Louisiana, where the cause of action arose. If that were a sufficient consideration for forbidding the filing of such a suit elsewhere than at the place where the cause of action arose, the defendant could, in almost every case, successfully demand that the action be brought where the cause of action arose. We cannot assume that the Congress of the United States, in allowing such an action to be brought in the district .... in which the defendant shall be doing business at the time of commencing such action,' did not have in mind the inconvenience that would result, in almost if not quite every case, from bringing the suit elsewhere than at the place where the cause of action arose." I53 La. at 23,95 So. at 388.

${ }_{101} 3{ }_{14}$ U. S. 44 (I94I).

${ }^{263}$ Annotation, Power to enjoin bringing or prosecution of action under Federal Employers Liability Act in another jurisdiction, $\mathrm{Ir} 3$ A. L. R. 1444 (1938).

${ }_{154}$ Annotation, Power to enjoin bringing or prosecution of action under Federal Employers' Liability Act in another jurisdiction, 136 A. L. R. 1232 (1942).

${ }_{205} 28$ AM. JUR. InJunctions \$2I7; Frankfurter, J., dissenting in Miles v. Illinois Cent. R. R., stipra note $15 \mathrm{I}$, at $7 \mathrm{xo}$.

${ }^{100}$ Miles v. Illinois Cent. R. R., supra note 15I, at 703; Bainbridge v. Merchants \& Miners Co., 287 U. S. 278 (1932); Doll v. Chicago Great Western R. R., 159 Minn. 323, r98 N. W. roo6 (r924). ${ }^{167} 292$ Fed. 326 (8th Cir. I923).

${ }^{158}$ Wabash Ry. v. Peterson, I87 Iowa 1331, 175 N. W. 523 (1919); In re Spoo's Estate, I9r Iowa I $344, x 83$ N. W. 580 (1921); Payne v. Knapp, I97 Iowa 737, 198 N. W. 62 (I923). 
Clearly enough the statute as thus construed conflicted with Section 6 of the FELA because it would prohibit, regardless of circumstances, a suit under the Act in any federal district court outside of Iowa. The court properly enough held that the federal statute could not be overruled in this fashion by state law. But the language it used in doing so with its references to the federal right created by the special venue clause gave strength later on to the idea that the clause created some sort of a special privilege of venue which would have to prevail even against an otherwise good equitable right to relief from an oppressive or vexatious suit. ${ }^{1684}$ The court did not intend to go that far. It overruled the railroad's contention that it was entitled to relief in that case on account of hardship, injustice, and oppression, because it said no such situation was presented under the facts. ${ }^{150}$ The court went on to grant a writ to restrain the railroad company from enforcing an injunction against a transported personal injury suit which the company had obtained in a state district court in Iowa. ${ }^{160}$

158a "The right of appellee to bring suit is given by the federal Employers' Liability Law, section 6.... We therefore have a situation presented where Congress has given $\dot{a}$ right by federal cnactment, and a state limits or destroys that right through an injunction of one of its courts based on a statc statute, on the theory that the exercise of the right would interfere with the public policy of the state.

"This public policy compels the citizen to give up a right granted by federal law. It is difficult to take seriously in this day of our national history the proposition that a state can be permitted so to destroy the power of a federal court to carry on the work given to it under the acts of Congress. If witnesses, by order of a state court, can be prevented from testifying in a federal court, then the federal court is a mere shell, to be crushed by the pressure of state court injunction. If a state can compcl a citizen to give up one federal right as a prerequisite to bringing suit in a federal court, it can compel him to give up all federal rights. It is a proposition fraught with amazing conscquences." Chicago, M. \& St. P. Ry. v. Schendel, 292 Fed. at 328-9.

150 "It is quite apparent that the equitable ground could not have been the reason for the injunction, as the order of the court practically prevented bringing suit in the Southern district of lowa, or in any other division of the Northern district, except the Cedar Rapids one. Suit could not have been brought either at Davenport, only a short distance from Cedar Rapids, or at Ottumwa-both places where the District Court for the Southern District of Iowa is held-and which could have resulted in no appreciable hardship. We do not feel called upon to discuss the cases cited where the courts have held that equity may enjoin citizens of one state from bringing action in other jurisdictions. They do not apply to this situation. We are satisfied that the order was not issued on equitable grounds of oppression or hardship, but on the ground that the public policy of the state was being violated." 292 Fed. at 334 .

${ }^{180}$ Schendel had brought suit as administrator in a state district court of Minnesota against the railroad for damages for the death of his intestate which occurred while the latter was in the cmploy of the railroad in Iowa. The railroad instituted suit in a state district court of Iowa to prevent the widow and witnesses from taking any step in aid of the suit in Minnesom or any suit brought on the same cause of action except in a federal court for the particular division or district of Iowa, or in a statc court of a specified county of Iowa. Schendel dismissed the original personal injury suit in Minnesota and refiled it in a federal district court in the same state. He brought an ancillary proceeding in the federal district court to restrain the railroad from interfering with the prosecution of the personal injury suit there and requiring it to dismiss the injunction suit in Iowa. The Eighth Circuit upheld the counter-injunction despite Section 265 of the Judicial Code prohibiting injunctions to be issued to stay the proceedings in state courts except in bankruptcy cases. Id. at 326 .

A contrary result was reached on the right of a federal court to enjoin proceedings in a state court under similar circumstances in Bryant v. Atlantic Coast Line R. R., 92 F. 2d 569 (2d Cir. 1937). The court (L. Hand, C. J.) said (p. $57 \mathrm{r}$ ) in commenting on the Schendel case: "Nor can we agrce with Chicago M \& St. P. Ry. v. Schendel, 292 F. 326 (C. C. A. 8), where the facts were on all fours with those at bar. The court's theory there was that, as the federal court had first acquired 'jurisdiction of the subject-matter of 'the cause of action' (292 F. 326 , at pages $332-334$ ), it might protect that juris- 
In McConnell v. Thomson, ${ }^{161}$ the Supreme Court of Indiana, which had consistently upheld the right of its courts to enjoin oppressive suits under the FELA brought in a state court in another jurisdiction, held that the same right did not exist to enjoin a suit in a remote federal district. McConnell, a brakeman in the employ of Thomson, trustee for a bankrupt railroad, lost his life in a fall from a freight car. The administratrix of the estate threatened to file for damages in a federal district court at St. Louis. Thomson was granted an injunction in an Indiana probate court restraining her from carrying out this intention. The Indiana Supreme Court reversed the judgment holding that it is beyond the power of a state court to enjoin a suit under the Act in a federal court. ${ }^{162}$

If comity were the reason for the rule against the issuance of an injunction in a state court to restrain an inequitable action in a federal court, it was clearly an unarticulated comity because other grounds are stated in the decisions.

The federal courts with a good deal of consistency refuse to enjoin suits under the Act in another federal court.

In Chesapeake \& Ohio R. R.v. Vigor, ${ }^{163}$ an employee was killed in the service of a railroad in Ohio where he had lived with his family. His administratrix brought suit in a federal district court in Indiana. The railroad company sought an injunction in a federal district court in Ohio against the maintenance of the Indiana action, alleging that it would place an unconscionable hardship on the railroad company and would burden interstate commerce. The court overruled both contentions, and denied an injunction. ${ }^{164}$ In doing so it assumed without much

diction. In so holding the court assumed to follow Kline v. Burke Construction Company, 260 U. S. 226, 43 S. Ct. 79, 67 L. Ed. 226, 24 A. L. R. ro77, but with great deference it does not seem to us that it did so. An action in personam is indeed in some sense a 'subject-matter' before the court where it is pending; conceivably its pendency should stay a later action in the court of another state, just as it often does-when both courts are of the same state-under the plea of lis alio pendens. But the very purpose of Kline v. Burke Construction Company, stupra, was to reaffirm-for it was an old dactrinethat two actions in personam upon the same cause of action may go on pari passu in different jurisdictions."

The Schendel case was finally overruled in Southern Railway Co. v. Painter, 3I4 U. S. I55 (I94I). The court (Frankfurter, J.) said (p. 159): "The restrictions of Sec. 265 upon the use of the injunction to stay a litigation in a state court confine the district courts even though such an injunction is sought in support of an earlier suit in the federal courts."

$A$ counter-injunction was issued out of a state court under similar circumstances in Peterson v. Chicago B. \& Q. Ry., I87 Minn. 228, 244 N. W. 823 (1933).

${ }_{101} 213$ Ind. 16,8 N. E. $2 d$ 986, II N. E. $2 d$ r83, Ir3 A. L. R. 1429 (I937).

102 ". . . But Congress can, and by the provisions of the Federal Employers' Liability Act, as construed and applied by the federal courts, has conferred upon any person asserting a cause of action under such act a federal right to bring the action in a District Court of the United States in the district in which the defendant may be doing business at the time of commencing such action; and has imposed upon such District Court the duty of accepting jurisdiction of such action. Consequently when a state court, as in the instant case, attempts to enjoin a litigant from prosecuting his cause of action, arising under the Federal Employers' Liability Act, in a District Court of the district in which the defendant is doing business, such action, if effective, destroys a federal right of the litigant and obstructs the performance of a duty imposed by act of Congress upon a District Court of the United States. This is beyond the power of a state court." 213 Ind. at 29-30, $8 \mathrm{~N}$. E. $2 \mathrm{~d}$ at $99 \mathrm{r}$.

${ }_{203} 90$ F. 2 d 7 (6th Cir. 1937), cert. denied, 302 U. S. 705 (1937).

186 The court said (p. 8), "The plaintiff, it is true, may suffer some inconvenience or be put to extra expense in producing witnesses to testify in court in the Indiana case, but it is to be presumed that Congress considered such probable inconvenience and expense in placing jurisdiction of the action in 
discussion that Congress intended Section 6 not as an ordinary rule of venue but as some special or absolute privilege of venue overriding the principles of law under which relief had been traditionally available from abuse of venue.

The same result was reached in Baltimore \& O.R.R.v. $\mathrm{Clem}^{\mathbf{1 0 5}}$ when an action was brought to enjoin a railroad employee, a resident of West Virginia, from bringing suit under the Act in a federal district at Cleveland, Ohio. The court denied the injunction refusing to follow its previous decision in Baltimore \& O.R.R. v. Bole $e^{100}$ because its attention had been called for the first time to Chesapeake \& O.R.R.v. Vigor. ${ }^{167}$ In Rader $v$. Baltimore \& $O . R . R .{ }^{168}$ the employee was injured in Ohio and brought suit under the Act in a federal district court in Chicago. The railroad company obtained an injunction in a state court of Ohio restraining the further prosecution of the personal injury suit in Illinois. The injunction was pleaded as one of the defenses in the damage suit. The circuit court of appeals upheld the lower court in striking the answer, saying that having first acquired jurisdiction the district court was under no duty to pay heed to the order.

\section{The Bars Come Down-The Kepner and Miles Cases}

The controversy over the right of a state court to enjoin an injured employee residing within the jurisdiction from bringing suit under the Act in a remote federal court reached the Supreme Court of the United States in Baltimore \& Ohio R. $R$. v. Kepner. ${ }^{169}$ Kepner was injured in Ohio where he lived while in the employ of the company. He brought suit under the Act for damages in the federal district court for the eastern district of New York. The railroad asked a state court in Ohio to enjoin him from its continued prosecution. While New York was 700 miles from the residence of the plaintiff and of numerous witnesses, the company was carrying on railroad operations there. To present the case properly would, it was asserted, require the personal attendance of approximately 25 locally available witnesses-the crew, inspectors, and medical attendants-at a cost estimated to exceed the cost of the presentation of the case at a convenient point by $\$ 4,000$. The right to an injunction was denied by a divided Court, three justices dissenting. The Court held that under its previous decisions ${ }^{\mathbf{1 7 0}}$ no relief could be given because of an undue burden on interstate commerce, since the railroad conducted physical operations in the state of the forum. While recognizing the right of a state court to prevent a resident under its jurisdiction from doing inequity by maintaining a vexatious and inequitable suit, it held that no such step could be taken to interfere with the priv-

any district in which the defendant should be doing business at the time. . . The defense of the case could not, of course, place an unreasonable burden on interstate commerce, for . . . Congress has the power to regulate interstate commerce, and may, when it sees fit, place incidental burdens thereon by jurisdictional statutes."

${ }_{105} 36$ F. Supp. 703 (N. D. W. Va. 194I).

1003 I F. Supp. 221 (N. D. W. Va. r940).

${ }^{107}$ Stspra, note 163 .

${ }^{108}$ 108 F. 2d 98I (7th Cir. 1940). See also Annotation, Power to enjoin bringing or prosecution of action under Federal Employers' Liability Act in another jurisdiction, I13 A. L. R. 1444 (1938). ${ }^{180}{ }_{31}$ U. S. 44 (I94I).

${ }^{170}$ Denver \& R. G. R. R. v. Terte, 284 U. S. 284 (1932); Hoffman v. Foraker, 274 U. S. 21 (1927). 
ilege of venue granted by the FELA. ${ }^{171}$ The Court referred briefly to the legislative history, and seemed to have been impressed with the fact that the special venue clause was passed in I9Io to cure the injustice to an injured employee of compelling him to go to the possibly far distant place of habitation of the defendant carrier. It was even more impressed with the statement of Senator Borah, in bringing up the bill in the Senate, that it was intended to permit the injured employee to sue the employer at any place where it was carrying on business if he chose to do so. ${ }^{\mathbf{1 7 2}}$

Justice Frankfurter spoke for the dissenters. ${ }^{173} \mathrm{He}$ found nothing either in the special venue clause or in its legislative history indicating an intention on the part of Congress to create a special federal venue privilege or to give a unique scope to this venue provision different from the significance accorded all other provisions of venue. He could find no intention to withdraw from the state courts powers historically exercised by them or to give an absolute command to the federal courts to take jurisdiction regardless of any considerations of justice, or fairness, or burden on interstate commerce. He thought that the majority had attributed too much weight to the casual general description by Senator Borah of the amendment of Igro. ${ }^{174}$

171 The Court said (Reed, J., 314 U. S. at 53-54): "The privilege was granted because the general venue provisions worked injustices to employees. It is obvious that no state statute could vary the venue and we think equally true that no state court may interfere with the privilege, for the benefit of the carrier or the national transportation system, on the ground of inequity based on cost, inconvenience or harassment. When the section was enacted it filled the entire field of venue in Federal courts. A privilege of venue granted by the legislative body which created this right of action cannot be frustrated for reasons of convenience or expense. If it is deemed unjust, the remedy is legislative, a course followed in securing the amendment of April 5, 19ro, for the benefit of employees."

${ }^{772}$ "The reason for the addition was said to be the injustice to an injured employee of compelling him to go to the possibly far distant place of habitation of the defendant carrier with consequent increased expense for the transportation and maintenance of witnesses, lawyers and partics away from their homes. The legislative history throws little light on the reason for the choice of the three standards for determining venue: the residence of the carrier, the place where it is doing business, or the place where the cause of action arose. At one time the amendatory bill fixed venue as the district of the residence of either the plaintiff or the defendant, or in which the cause of action arose, or in which the defendant shall be found at the time of commencing such action.' Fears were expressed that so wide a choice might result in injustice to the carrier, p. 2257. No doubt this language was actually considered by the Senate Judiciary Committee as well as the language of the general venue statute for which the Committee was providing an exception. Specific attention was called in the Senate report to the Macon Grocery $\mathrm{Co}$. case, interpreting the general venue statute. That statute placed venue in the residence of either party where the jurisdiction was founded on diversity of citizenship alone. The language finally adopted must have been deliberately chosen to enable the plaintiff, in the words of Senator Borah, who submitted the report on the bill, to find the corporation at any point or place or State where it is actually carrying on business, and there lodge his action, if he chooses to do so." Id. at 49-50.

${ }^{173}$ The other two dissenters were Chief Justice Stone and Justice Roberts.

17t Justice Frankfurter said in part: "To read the venue provision of the Act as do the majority of the Court is to translate the permission given a plaintiff to enter courts previously closed to him into a withdrawal from the state courts of power historically exercised by them, and into an absolute direction to the specified Federal and state courts to take jurisdiction. The implications of such a construction extend far beyond the situation we now have here of an attempt by a state court to enjoin an action brought in a Federal court sitting in another state. . . The long history of leaving the effective enforcement of Federal rights to state courts has proceeded on recognition of the power of state courts to exercise in the first instance their settled doctrines of law and equity. The opinion of the Court ignores these settled principles. In an area demanding the utmost judicial circumspection, dislocating uncertainty is thereby introduced.

"If the privilege afforded a plaintiff to bring suit under the Employers' Liability Act in one place rather than in another is to be regarded as an absolute command to the Federal courts to take jurisdiction 
The majority opinion only scratched the surface of the legislative history of the special venue clause, and the few fragments it came up with were hardly sufficient to warrant the sweeping finding of a congressional intention to create a unique special venue privilege overriding the ordinary rules of law providing for checks on abuses of venue. It did not say that Congress had expressly considered displacing, by the language of the amendment, the established legal and equitable remedies for abuse of venue. It could not say so, for the subject was not brought up during congressional consideration of the amendment. It gave only a partial statement of the purpose of the legislation when it said that the reason for the addition was to avoid the injustice to an injured employee of compelling him to go to a district in the state of incorporation of the employing railroad. Both committees, House and Senate, said as much, but they preceded this with the assertion that "this amendment is necessary in order to avoid great inconvenience to suitors"-to both parties rather than just to the plaintiff, one would think. ${ }^{175}$ It ignored the fact that at the hearings both employers and employees supported the amendment because the existing law worked inconvenience on both of them. Also lost sight of was the important circumstance that the real objective sought was to permit these suits to be kept at home, not to facilitate their transportation to distant points, and that when question was raised about the possibility of transportation of suits by plaintiffs under the liberalized venue, assurance was given that nothing of the sort was likely to happen. ${ }^{170}$ The Court ignored many other features of legislative history possessing no little significance. It lost sight of the statement of Representative Sterling, who was in charge of the bill in the House, that the bill would not in any way enlarge the jurisdiction of the federal courts or curtail the jurisdiction of the state courts. The ban on removal of cases from state to federal courts was inserted because of a feeling, as stated by Senator Dixon, one of its proponents, "that these cases ought to be litigated in the community where the cases arise and not be transferred to a foreign community or a foreign court."177 Mr. Sterling said, "This bill simply provides the same rule in reference to the place of bringing suit that is provided in practically all of the States of the Union."178 It also lost sight of Senator Borah's declaration that everybody was agreed with President Taft that the objective

regardless of any considerations of justice and fairness, why is not the same effect to be given the comparable general venue provisions of Sec. 51 of the Judicial Code, 28 U. S. C. A. \$II2? Nothing in the language or the history of the venue provision of the Act differentiates it from the numerous other venue provisions of the Judicial Code. Is the settled doctrine of forum non conveniens to be deemed impliedly repealed by every such venue provision? Surely it is much more consonant with reason and right to read venue provisions in the familiar context of established law rather than to impute to Congress an unconsidered, profound alteration in the relationship between the Federal and the state courts and in the relations of the Federal courts inter se. Cf. Gay v. Ruff, 292 U. S. 25,78 L. Ed. I099, 54 S. Ct. 608, 92 A. L. R. 970." 314 U. S. at 6r-62.

${ }^{175}$ The full sentence reads: "This amendment is necessary in order to avoid great inconvenience to suitors and to make it unnecessary for an injured plaintiff to proceed only in the jurisdiction in which the defendant corporation is an 'inhabitant." " House Rep. 513, 6rst Cong., 2d Sess. 6 (Fcb. 22, 1910); Sen. Rep. 432, 6Ist Cong., 2d Sess. 4 (March 22, 1910).

${ }^{170}$ Sce note 22, supra.

${ }^{17 \pi} 45$ CONG. REC. 4092 (1910).

178 See note 20, supra. 
was that "The right to bring the suit under this act should be as easy of enforce_ ment as the right of a private person not in the company's employ to sue on an ordinary claim," a requirement which called for only an ordinary rule of venue rather than for some unique special federal privilege.

Once it was decided that the amendment of Igro created a special federal venue privilege, it became doubtful whether any interference with its exercise would be sanctioned. In the Kepner case, where the principle was first laid down by the Supreme Court, it was determined that there could be no interference by an injunction issuing from a state court against the exercise of the privilege in a federal court.

There remained the question whether the ban would apply to a proceeding to halt its exercise in another state court, and this question was raised in the following year in Miles $v$. Illinois Central $R . R^{179}$ Miles suffered a fatal accident while in the employ of the railroad at Memphis, Tennessee. His administrator brought suit in a state court in Missouri. The railroad countered with an action in a state court in Tennessee to enjoin the decedent's widow and children from prosecuting the Missouri suit, alleging that it would entail inconvenience and expense to the railroad and a burden upon interstate commerce. Although the railroad had apparently abandoned its contentions with respect to the burden on interstate commerce, the Supreme Court reiterated its holding in the Kepner case that the carrier must submit to inconvenience and expense if there is jurisdiction although thereby interstate commerce is incidentally burdened.

On the main point the Court held that the right to sue in state courts is no more subject to interference by state action than was the federal venue in the Kepner case, and the normal expense and inconvenience of trial in permitted places is not to be regarded as inequitable and unconscionable. The Missouri court, it said, must permit this litigation in view of the privileges and immunties clause of the Constitution, although the state may regulate the use of its courts generally as was recognized in the Douglas and Chambers cases, and may determine the venue in its own courts. ${ }^{180}$ Justice Jackson, who was one of the five-man majority, delivered

270315 U. S. 698 (1942).

180 The Court (Reed, J.) said: "In the legislative history of Sec. 6, the provision that removal may not be had from a 'state court of competent jurisdiction' was added to the House bill on the floor of the Scnate and later accepted by the House, in order to assure a hearing to the employee in a state court. Words were simultaneously adopted recognizing the jurisdiction of the state courts by providing that the federal jurisdiction should be concurrent. The venue of state court suits was left to the practice of the forum. The opportunity to present causes of action arising under the Federal Employers' Liability Act in the state courts came, however, not from the state law but from the federal. . . . The Missouri court here involved must permit this litigation. To deny citizens from other states, suitors under Fedcral Employers' Liability Act access to its courts would, if it permitted access to its own citizens, violate the Privileges and Immunities Clause, Constiution, Art. 4, Sec. 2; McKnett v. St. Louis \& S. F. R. Co., 292 U. S. 230, 233. Since the existence of the cause of action and the privilege of vindicating rights under the Federal Employers' Liability Act in state courts spring from federal law, the right to sue in state courts of proper venue where their jurisdiction is adequate is of the same quality as the right to sue in federal courts. It is no more subject to interference by state action than was the federal venue in the Kepner case.

"This is not to say that states cannot control their courts. We do not deal here with the power of Missouri by judicial decision' or legislative enactment to regulate the use of its courts generally as was approved in the Douglas or the Chambers cases, supra, note 6 . We are considering another state's 
a concurring opinion, while Justice Frankfurter, joined by Chief Justice Stone and Justices Roberts and Byrnes, spoke for the four dissenters.

Justice Jackson in his concurring opinion agreed with the four dissenters that if the Court were free to consult the ultimate public interest in orderly resort to the judicial system it should prevent the transportation of law suits to distant and inconvenient forums. He though the statute, however, gave the plaintiff the right to choose from the entire territory served by the railroad. While it may well be admitted, he said, that the privilege to go shopping for a favorable judge or jury puts a burden on interstate commerce, Congress nevertheless has, and has exercised, the power to burden. He regarded the FELA as leaving interstate commerce under the burden of a medieval system of compensating the injured railroad worker or his survivors. He expressed disagreement with Justice Reed's statement that the Missouri court must permit the litigation. He agreed here with the four dissenting justices, and his views therefore were those of the majority of the court. ${ }^{181}$

Justice Frankfurter, speaking for himself and the three other dissenters, thought (at pp. 708, 709) that "the decision in this case mutilates principles that have long been regarded as basic in the law"-among them those under which a court may prevent injustices by restraining a person subject to its authority from maintaining an inequitable suit in the courts of another state. There is nothing, he said, in the language of the Act to require a disregard of these principles so the majority's decision to the contrary must be found "in the inarticulate radiations of $\$ 6$ of the I9Io amendment." The language of the amendment regarding concurrent jurisdiction of state and federal courts instead of granting jurisdiction to the state courts merely presupposes that they already possessed it, and he quoted statements from Representative Sterling and Senator Borah while the amendment was under consideration as conclusive proof that Congress did not insert this provision in order to cut down the normal powers of state courts.

The attack on Pearl Harbor intervened between the Kepner and the Miles cases. The destruction of two of the principal checks on the solicitation and transportation

power to so control its own citizens that they cannot exercise the federal privilege of litigating a federal right in the court of another state. ...

"The permission granted by Congress to sue in state courts may be exercised only where the carrier is found doing business. If suits in federal district courts at those points do not unduly burden interstate commerce, suits in similarly located state courts cannot be burdensome. As Congress has permitted both the state and federal suits, its determination that the carriers must bear the incidental burden is a determination that the state courts may not treat the normal expense and inconvenience of trial in permitted places, such as the one selected here, as inequitable and unconscionable." 315 U. S. at 702-5.

181 "Unless there is some hidden meaning in the language Congress has employed, the injured workman or his surviving dependents may choose from the entire territory served by the railroad any place in which to sue, and in which to choose either a federal or a state court of which to ask his remedy. There is nothing which requires a plaintiff to whom such a choice is given to excrcise it in a self-denying or large-hearted manner. ...

"It seems more probable that Congress intended to give the disadvantaged workmen some leverage in the choice of venue than that it intended to leave him in a position where the railroad could force him to try one lawsuit at home to find out whether he would be allowed to try his principal lawsuit elsewhere. This latter would be a frequent result if we upheld the contention made in this case and in the Kepner case. I think, therefore, that the petitioner had a right to resort to the Missouri court under the circumstances of this case for her remedy." 3 I5 U. S. at 706-708. 
of suits under the Act opened the way for resumption of the abuses during wartime. They reappeared in virulent form. Since the railroads remained in private hands, there was no statutory authority such as the Director General of Railroads had exercised in World War I under the Federal Control Act in promulgating General Orders 18 and I8-A. This was the conclusion reached in Union Pacific R. R. $v$. Utterback. ${ }^{182}$ Utterback and Thatcher, employees of the railroad company, lost their lives in an accident near Portland, Oregon. Their survivors secured the appointment of Charlotte $E$. Leet as administratrix of each estate, and she brought suit for damages in the Superior Court of California at Los Angeles, I, 150 miles away from Portland. The railroad thereupon sought in a state court in Oregon to restrain the defendants from prosecuting the California actions. Among the defendants was Mr. Clifton Hildebrand, an attorney practicing in California, who filed the action on behalf of the administratrix. It was alleged that he had filed between I940 and I942 fifty damage actions for injuries to railroad employees in accidents occuring outside of California, and had in conjunction with the administratrix conspired to institute the instant cases for the purpose of obtaining either a grossly excessive amount in settlement of the cases or a grossly excessive award of damage from a Los Angeles jury. Detailed allegations were made with respect to the operating difficulties of the railroad and the handling of emergency war traffic, and regarding the shortage of manpower for that purpose, rendering it inconvenient to the railroad and harmful to the war effort to take the twenty-odd defense witnesses from Portland to Los Angeles for the trial. The railroad attempted to distinguish the Kepner and Miles cases because of the greatly different situation brought about by the war, contending it was placed in the dilemma of having to choose between (a) waiving its defenses to two damage claims, one for \$roo,000, the other for $\$ 50,000$, which it believed to be without merit, or (b) violating its carrier obligations during a period of national peril and thus exposing itself to resulting penalties. The court, however, held the special venue clause as interpreted in the Kepner and Miles cases precluded the granting of relief, saying that although the President, through the Secretary of War, could have made an order restricting the venue of suits, he had not done so. ${ }^{183}$

${ }^{182} 173$ Ore. 572 , 146 P. $2 \mathrm{~d} 76,769$ (1944), cert. denied, 323 U. S. 7 II (I944).

183 "We think, therefore, that the President through the Secretary of War would be warranted in making an order restricting the venue of suits against carriers under general control, either complete or supervisory, while such carriers were engaged in transporting troops, munitions or military supplies, if and when, in the judgment of the President, the practice reflected in plaintiffs' complaints was prejudicial to the just interests of the government in the prosecution of the war. Alabama \& V. R. Co. v. Journey 257 U. S. III, 42 S. Ct. 6, 66 L. Ed. I54.

"We cannot, however, bring ourselves to believe that, even to promote the prosecution of the war effort, in the absence of any such order a state court of one state may enjoin the continuance of litigation pending in the court of another state where venue is expressly given to the latter by an Act of Congress.

- • •

"We cannot subscribe to the principle that upon the sole ground of military expediency while a war is in progress the civil courts should be held to have the right and to be charged with its attendant duty to intrude their judgment with respect to the necessity or advisability of suspending the operation of the provisions of an Act of Congress. We think that in time of war such a course would be an encroachment upon the prerogative of the Commander in Chief of the military forces." I73 Ore. at 584$586, x_{44}$ P. $2 \mathrm{~d}$ at $80-8 \mathrm{x}$. 
The railroad company not only sought to obtain an injunction in Oregon against the maintenance of the Thatcher and Utterback suits, but also filed motions in the Superior Court of Los Angeles to abate the action or to continue the trial of them indefinitely on the grounds of forum non conveniens. These motions were denied, and the Supreme Court of California affirmed. ${ }^{184}$ That court held that the doctrine of forum non conveniens furnishes no justification for a state court to refuse jurisdiction of an action under the FELA, citing many of the previous decisions on the subject, including the Kepner and Miles cases. ${ }^{185}$ Three of the justices dissented, holding that a state court has power to refuse jurisdiction on the ground of fortum non conveniens, and pointing out that the majority of the members of the Supreme Sourt of the United States had so held in the Miles case. ${ }^{180}$

When the bars were let down in the Kepner and Miles cases the length of haul began to grow. Previously for the most part claims had been imported from adjoining or adjacent states. In the Kepner case it was 700 miles from Ohio to New York. In the Utterback case it was 1150 miles from Portland, Oregon, to Los Angeles. Eventually it reached almost from ocean to ocean. The Southern Pacific Company with eastern termini at Ogden and New Orleans was held to be doing business in New York and therefore subject to suit under the Act by an administrator for the death of an employee living and working in Arizona where he maintained his residence at the time of his death. ${ }^{187}$

The Texas and Pacific Railway Company, operating in Texas, Arkansas, and Louisiana, was similarly held subject to suit in New York at the instance of an employee injured in the state of Texas and having his residence there 2000 miles

${ }^{184}$ Leet v. Union P. R. R., 25 Cal. 2d 605, 155 P. 2d 42, 158 A. L. R. 1008 (1944).

185 "The rule of forum non conveniens is an equitable one embracing the discretionary power of a court to decline to exercise the jurisdiction it has over a transitory cause of action when it believes that the action before it may be more appropriately and justly tried clsewhere. If the plaintiff by reason of section 56 has an absolute right to have the action tried in the named courts, there is no room for the doctrine. It has been repeatedly held that the right to have an action brought under the act tricd in one of the mentioned federal district courts is absolute. . . .

"The Miles case is completely decisive that the doctrine of forum non conveniens is no justification for a state court to refuse jurisdiction of an action under the Federal Employers' Liability Act. Likewise, it is conclusive that the state court must take jurisdiction. It has no choice in the matter and no rule or policy on its part alters the situation." 25 Cal. 2d. at 609, 612, 155 P. 2d at 44, 46.

186 "In the Miles case, Justices Frankfurter, Roberts, Byrnes and Chief Justice Stone were of the opinion that 'Section 6 did not give the state courts compulsive jurisdiction;' and Justice Jackson, in sharing that view, stated: It is very doubtful if any requirement can be spelled out of the Federal Constitution that a state must furnish a forum for a nonresident plaintiff and a forcign corporation to fight out issucs imported from another state where the cause of action arose." 25 Cal. $2 \mathrm{~d}$ at 624,155 P. $2 \mathrm{~d}$ at 52 .

${ }^{187}$ Butts v. Southern Pac. Co., 69 F. Supp. 895, 896 (S. D. N. Y. 1947): "Baltimore \& Ohio Railroad Co. v. Kepner, I94I, 314 U. S. 44,62 S. Ct. 6, 86 L. Ed. 28 , 136 A. L. R. 1222 pnd Miles v. Illinois Central R. Co., r942, 315 U. S. 698,62 S. Ct. 827, 86 L. Ed II29, 146 A. L. R. 1104, regardless of their precise holdings, say enough to preclude a district judge, once the statutory critcria of venue are satisfied, from dismissing an action under the Federal Employers' Liability Act on the ground that the action constitutes an unlawful burden upon interstate commerce or on the ground of forum non conveniens."

The court dismissed Douglas v. New York, New Haven \& Hartford R. R., 279 U. S. 377 (1929), as merely holding that a state court was not required by the Act to entertain the suit if it violated the state's conception of forum non conveniens, but having no application to a fedcral court. 
from the place of trial. ${ }^{188}$ The court held that the Kepner and Miles cases unconditionally eliminated any consideration of forum non conveniens in a suit under the FELA, citing the statement to that effect by the Supreme Court in Gulf Oil Corp. $v$. Gilbert. ${ }^{189}$ It held that the company was doing business in New York by virtue of a continuous solicitation of business, under International Shoe Company v. Washington. ${ }^{190}$ In the latter case, however, the suit arose out of the corporation's activities in Washington and that fact was one of the elements relied upon by the Court in holding it subject to suit there.

The Milwaukee Railroad, operating from Chicago to the Pacific coast and with no line east of Indiana, was held to be subject to suit under the Act in New York, where it was engaged in business, at the instance of an employee, a resident of lowa who was there injured in its service. ${ }^{191}$ The court denied a motion to dismiss made on the ground that the action constituted an unlawful burden on interstate commerce and on the ground of forum non conveniens.

The Butte, Anaconda and Pacific Railway Company, operating a line of railroad located entirely in Montana, was sued in New York under the Act by an administratrix of an employee of the company killed while in its service in Montana. A motion to dismiss was denied on the ground that the company was doing business in New York. ${ }^{192}$

On the other hand, where the Southern Pacific Company was sued in New York by a person not in its employ who was a nonresident of the district, a different result was reached because the FELA had no application. The cause of action arose elsewhere and no part of the transaction had any connection with the events occurring in New York. The company did not maintain or operate any part of its railroad system in the district although it was doing business there by reason of maintenance of financial, traffic and legal offices there. A motion to dismiss was sustained on the ground of undue burden on interstate commerce. ${ }^{193}$

\section{Atrempts at Legislattve Relef by Amendament of Spectal Venue Clause}

In 1947, an effort was made to amend Section 6 of the FELA. Representative Jennings of Tennessee introduced H. R. $1639,{ }^{194}$ which proposed a substitute for the venue clause providing that an action may be brought only in a district court of the United States or in a state court of competent jurisdiction in the district or county, respectively, in which the accident occurred, or in which the employee suffering injury or death resided at the time when the accident occurred, and containing a proviso that if the defendant could not be served with process issuing ${ }^{188}$ Kilpatrick v. Texas \& Pacific Ry., I66 F. 2d 788 (2d Cir. 1948), cert. denied, 335 U. S. 8I4 (1948).

\footnotetext{
${ }_{180} 330$ U. S. 501 ( 1947$)$.

100326 U. S. 310 (1945).

101 Nunn v. Chicago M. St. P. \& Pac. R. R., 7I Supp. 54 I (S. D. N. Y. I947).

${ }_{102}$ Pickthall v. Anaconda Copper Min. Co., 73 F. Supp. 694 (S. D. N. Y. I947).

${ }^{105}$ Jablonski v. Southern Pae. Co., 76 F. Supp. 1022 (S. D. N. Y. 1948).

1" H. R. 1639, 8oth Cong., Ist Sess. (1947).
} 
out of any such courts the plaintiff might bring his action in any court, state or federal, where the defendant might be doing business. ${ }^{105}$

Representative Jennings said that he had introduced the bill because the practice of solicitation of claims became so flagrant in his home city of Knoxville, Tennessee, that the local bar association, of which he was a member, passed resolutions advocating amendment of the special venue clause of the Act. He was also, he said, moved by a belief that existing venue permitted an injustice to carriers which was never envisioned by Congress when the Igro amendment was passed. ${ }^{100}$

The witnesses who supported the bill emphasized that the venue clause had been converted into an instrument for soliciting claims and fomenting litigation which had become a public scandal. It was, they said, not only unjust and oppressive on the railroads but also a burden on interstate commerce. The bill was supported by the American Bar Association and the bar associations of 39 states, as well as hundreds of local bar associations, as an appropriate remedy for the evil of the solicitation and transportation of personal injury claims in the railroad field. ${ }^{107}$ The chief opposition to the bill came from the railroad unions. They took a position quite different from the one assumed when the rgro amendment was under consideration. Their spokesmen in I9ro had protested against the necessity of going a long distance to sue in the state of incorporation of the railroad. Their whole emphasis was on the right to a trial near home or near the vicinity where the witnesses resided. In 1947 , under the leadership of the Brotherhood of Railroad Trainmen whose regional counsel were among those engaged in the transportation of claims to distant locations, they defended the practice as one necessary to secure adequate damages for injured employees. ${ }^{188}$ They contended that the bill would discriminate against the injured railroad employee because other persons having a transitory cause of action could maintain a suit wherever defendant was doing business or was present and could be served with process.

195 The body of:H. R. I639 read as follows: "Under this Act an action may be brought in a district court of the United States or in a State court of competent jurisdiction, in the district or county (parish), respectively, in which the accident occurred, or in which the employee suffering injury or death rcsided at the time when the accident occurred: Provided, That if the defendant cannot be served with process issuing out of any of the courts aforementioned, then and only then, the action may be brought in a district court of the United States, or in a State court of competent jurisdicion, at any place where the defendant shall be doing business at the time of the institution of said action. No case arising under this chapter, brought in any State court of competent jurisdiction, as herein provided, shall be removed to any court of the United States."

${ }^{190}$ Hearings before Subcommittee No. 4 of the House Committee on the Judiciary on H. R. 1639, 8oth Cong., Ist Sess. I2 (1947).

${ }^{197}$ In its report of May 7, I948, to the full committee (see note 97, supra), the subcommittec on the Judiciary of the Senate remarked (p. 5): "The organized bar in virtually every community in the United States has become increasingly aware of the flagrant practice of solicitation and transportation of cases arising under the Employers' Liability Act. Prior to the introduction of H. R. I639, many State and local bar associations had passed resolutions in favor of a limitation of venue under the act. At the present time the American Bar Association and the bar associations of 39 States have passed resolutions advocating enactment of legislation embodying the principles of H. R. I639. In addition, hundreds of city and county bar associations have endorsed the bill."

${ }^{108}$ Hearings before Subcommittee No. 4 of the House Committee on the Judiciary on H. R. 1639, 8oth Cong., Ist Sess. 45-113 (1947); Hearings before a Subcommittee of the Senate Committce on the Judiciary on S. 1567 and H. R. 1639, 80th Cong., 2d Sess., 119, 154, 122, 157, 215, 243, 275, 289 (r948). 
The House Judiciary Committee made a favorable report on the bill. There were 8 dissents on the 27-man committee and two minority reports. The majority decided to restrict the venue in all personal injury cases against railroads rather than only in those brought by employees. To that end it rewrote H. R. 1639 by striking from the venue clause everything except the ban on removal of cases from state courts and by proposing a new paragraph to be added to Section $5^{I}$ of the Judicial Code providing that civil suits for damages for wrongful death or personal injuries against any interstate common carrier by railroad might be brought at the places named in the original draft of H. R. I639.

A minority report made by Representative Devitt and concurred in by 6 other members proposed to amend Section 6 by providing that suits under the Act may be brought under the general federal venue statute except that they must be brought in a federal district court where plaintiff resides or where the interstate common carrier by railroad operates trains. Representative Devitt and his associates thought that their amendment would make the doctrine of forum non conveniens applicable in cases brought under the Act since under recent decisions it was applicable to actions brought under the general venue statute. The second minority report subscribed to by one member opposed any change.

The general consensus of the Judiciary Committee as a whole may be gauged from two sentences of the Devitt report: $:^{199}$

It is admitted that certain unethical attorneys solicit cases under the Federal Employers' Liability Act and transport them to far distance places for trial and that such lawyers employ touts and runners to solicit business for them, all to the detriment of the legal profession, the railroad workers, the railroads and the general public. . . . It is admitted that some action must be taken to correct the situation.

The majority bill passed the House. In the Senate it was referred to the Committee on the Judiciary, which in turn referred it to its Subcommittee No. 4 which held hearings even more extensive than those in the House. The subcommittee in a report of May 7,1948 , to the full committee recommended the passage of the bill with amendments which abandoned the idea of changing the Judicial Code so as to govern all personal injury suits against railroads, and reverted to the original idea of amending Section 6 of the FELA. ${ }^{200}$ The bill, however, died in the full committee. But another effort to obtain legislative relief was more successful.

\footnotetext{
${ }^{100}$ House Rep. No. 613, 80th Cong., Ist Sess. (June 19, I947).

200 The subcommittee proposed to amend the venue clause of Section 6 to read as follows: "Beginning with line 8 , page $I$, strike out all through line $2 \mathrm{I}$, page 2 , and insert in lieu thereof the following:

"Under this Act, suit may be brought only in any district court of the United States within, or in a State court of competent jurisdiction of, (I) the State in which the cause of action arose, or (2) the State of which the person suffering injury or death was a resident at the time the cause of action arose: Provided, That if, at any time within the period during which suit on any such cause of action shall not be barred by limitation, the interstate common carrier against which such cause of action is asserted shall either not have an office, for the transaction of business, within the State in which the cause of action arose or shall not have an office, for the transaction of business, within the State of which the person suffering injury or death was a resident at the time the cause of action arose, in that event such suit may, without it being necessary that suit shall have been previously brought in
} 


\section{Legislative Relief Secured-Transfer of Cases Under Forum Non Conveniens Rule}

Contemporaneously with the consideration of the Jennings bill the judiciary committees of the House and Senate were working on a comprehensive revision of the Judicial Code. For that purpose they engaged the services of an advisory committee, including distinguished judges and members of the bar, and also employed special consultants. ${ }^{201}$ One of the changes proposed was the addition to the Judicial Code of a new Section I404(a), providing, "for the convenience of parties and witnesses in the interest of justice, a district court may transfer any civil action to any other district or division where it might have been brought." 'The revisers' note, submitted to both committees and to the membership of both the House and the Senate, explained the reason for the proposal as follows: ${ }^{202}$

Subsection (a) was drafted in accordance with the doctrine of forum non conveniens, permitting transfer to a more convenient forum, even though the venue is proper. As an example of the need of such a provision, see Baltimore \& Ohio R. Co. v. Kepner, 194r, 62 S. Ct. 6,314 U. S. 44,86 L. Ed. 28 , which was prosecuted under the Federal Employers' Liability Act in New York, although the accident occurred and the employee resided in Ohio. The new subsection requires the court to determine that the transfer is necessary for convenience of the parties and witnesses, and further, that it is in the interest of justice to do so.

The revised Judicial Code was passed by both Houses of Congress and became law, ${ }^{203}$ effective September I, I948.

Thus Congress decided to afford relief not by the passage of legislation directed to the FELA alone, but by providing for the transfer of venue under the doctrine of forum non conveniens in all civil cases.

The applicability of the transfer under Section $1404(a)$ to a case arising under the FELA was challenged in Ex parte Collett. ${ }^{204}$ The petitioner instituted a damage suit against the Louisville and Nashville Railroad in the United States district court for the Eastern District of Illinois. The railroad filed a motion to transfer

any heretofore-mentioned court, be, subject, however, to the doctrine of forum non conveniens, at such time brought in any district court of the United States within or in a State court of competent jurisdiction of, any State in which such carrier then has an office for the transaction of business: Provided further, That nothing herein contained shall be construed to render inapplicable, in any suit brought in a State court, the law of that State providing for venue of actions, or change of venue of actions: And provided further, That if said common carrier shall have caused any such person suffering such injury or death to be transported for treatment for the injury aforesaid, or for the injury from which death resulted, to a hospital in any State other than that in which the cause of action arose or other than that of which such person was a resident at the time of such injury, in that event suit may be brought, by the person so injured or the person by whom liability for such death may be sought to be enforced, in the State in which said hospital is located. No case arising under this Act and brought in any State court of competent jurisdiction shall be removed to any court of the United States."

${ }_{201}$ See Ex parte Collett, 337 U. S. 55, 66 (1929). The consultants were Judge Alexander Holtzoff, United States district judge, District Court for the District of Columbia, and Professor James W. Moore of Yale University.

${ }^{202}$ H. R. REP. No. 308, 80th Cong., Ist Sess., A-I32 (1947); H. R. REP. No. 2646, 79th Cong., 2d Sess., A-r27 (r946).

${ }_{203}^{28} 28$ U. S. C. $\$ 1404\left(\right.$ a). $\quad{ }^{204} 337$ U. S. 55 (x949). 
the case to the district court for the Eastern District of Kentucky. All thirty-five witnesses and Collett himself lived in Irvine, Kentucky, which was the scene of the accident. Irvine is 400 miles from East St. Louis where the suit was brought. The district court granted the railroad's motion. The petitioner then filed in the Supreme Court a motion for leave to file petition for writs of mandamus and prohibition against the district court. He contended that the order of transfer exceeded the district court's authority because Section I404(a) is inapplicable to any proceeding governed by Section 6 of the FELA. It is inapplicable, petitioner urged, because to hold otherwise would mean that Section I404(a) had effected an implied repeal of the special venue clause found in Section 6 of the FELA. The Court rejected this contention, holding that by the clear and unambiguous language of Section I404(a) it applies generally to "any civil action" including those brought by railroad employees under the Act. There was no implied repeal of Section 6 since it deals with the places where actions may be brought originally, whereas Section 1404 (a) deals with the right to transfer an action properly brought. The Court also held that the legislative history of the revision of the Judicial Code required the same conclusion, especially in view of the recommendation by the revisers for the enactment of Section I404(a) to overcome the effect of the decision in the Kepner case. The Court based its holding that there had been no implied repeal in part upon the proposition that the bar to interference by judicial action with venue at any of the places enumerated in Section 6 came not from the language of that Section but from the judicial gloss upon it. ${ }^{205}$

Justices Black and Douglas dissented for the reasons stated in the dissenting opinion of the latter in United States $v$. National City Lines, ${ }^{208}$ another case decided the same day, in which the Court held that the transfer provisions of Section

${ }^{200}$ Chief Justice Vinson said (pp. 60-6r) on this point: ". . . We cannot agree that the order before us effectuates an implied repeal. The inapplicability of forum non conveniens to Liability Act suits derives from the Kepner decision. And there this Court expressly stated that if it is deemed unjust, the remedy is legislative. . 3 314 U. S. at 54. That opinion discusses Section 6 of the Liability Act, to be sure, but this Court did not and could not suggest that the legislative answer had necessarily to be addressed to that Section. Since the words selected by Congress for Sec. 6 denote nothing, one way or the other, respecting fortm non conveniens, there was no occasion to repeal that section, expressly or impliedly; Congress chose to remove its judicial gloss via another statute. Discussion of the law of implied repeals is, therefore, irrelevant."

${ }^{200}$ In this short dissent, Justice Douglas said (337 U. S. $78,84-85$ ): "There are difficulties for me however the case is decided. But I have concluded that the fairer result is reached if the ambiguities and doubts, fully canvassed and disclosed in the Court's opinions in this case and in Ex parte Collett, ante, p. 55, decided this day, are resolved by reading Sec. 1404 (a) as making the doctrine of forum non conveniens applicable to any civil action as to which the venue provisions are codified in revised Title 28. That gives full effect to the words 'any civil action' in the field in which Congress was legislating. And it authorizes, as respects that group of cases, a transfer to another district in lieu of outright dismissal as had previously obtained. That construction saves Sec. $1404(\mathrm{a})$, the venue provisions of the Clayton Act and our decision in United States v. National City Lines, Inc., 334 U. S. 573, from mutilation. I am reluctant to conclude that Congress took the more drastic course in a mere revision of the code. So to hold would make a basic change not only in the two statutes involved in these cases but in the Sherman Act, 15 U. S. C. Sections 4, 5; the Jones Act, 46 U. S. C. Sec. 688; the Suits in Admiralty Act, 46 U. S. C. Sec. 782; Merchant Marine Act of 1936,46 U. S. C. Sec. .1128d; the Securities Act, 15 U. S. C. Sections 77a, 77v; the Securities Exchange Act, 55 U. S. C. Sections $78 \mathrm{a}$, 78aa; the Public Utility Holding Company Act, 15 U. S. C. Sections 79, 79y; the Investment Company Act, 15 U. S. C. Sections 80a-r, 80a-43; and perhaps in other statutes too." 
I404(a) were applicable to civil suits by the government against corporations under the antitrust laws.

Since its enactment, Section $1404(a)$ has been applied in a number of cases, in some of which transfer has been granted while in others it has been denied. It has sent back to the normal situs many cases that have been filed elsewhere, usually at a considerable distance away. ${ }^{207}$ In other instances transfer has been denied, usually because the claim had not been transported a long distance and defendant was not shown to be substantially inconvenienced. ${ }^{208}$

The decisions in the Miles and Kepner cases had cast a cloud over the applicability of the doctrine of forum non conveniens in actions brought under the FELA in state courts even though the holding in neither case went so far as to affect the right of a state court to refuse to entertain a foreign suit brought by a nonresident where, in its judgment, the convenience of parties and witnesses in the interest of justice would be disserved. Dicta in Gulf Oil Company v. Gilbert ${ }^{200}$

${ }^{207}$ Kilpatrick v. Texas \& Pacific Ry., 337 U. S. 75 (1949) (accident at Big Spring, Texas; suit filed, District Court, Southern District, New York; transferred to Northern District, Texas); Larsen v. Nordbye, 18I F. 2d 765 (8th Cir. 1950) (cause of action transferred from District of Minnesota to Southern District, Iowa, where cause of action arose); Atlantic Coast Line R. R. v. Davis, 185 F. $2 d$ 766 (5th Cir. 1950) (transferred from Southern District, New York, to Southern District, Florida, where cause of action arose); Hayes v. Chicago R. I. \& P. R. R., 79 F. Supp. 821 (D. Minn. 1948) (cight cases embraced in the opinion; one case transferred from District of Minnesota, 4 th Division, to Northern District, Texas, Amarillo Division, where case arose; six cases transferred from District of Minnesota, $4^{\text {th }}$ Division, to Western District, Oklahoma, where causes of action arose; one case transferred from District of Minnesota, 4th Division, to Southern District, Illinois, Northern Division, where cause of action arose); Nunn v. Chicago, M. St. P. \& Pac. R. R., 80 F. Supp. 745 (S. D. N. Y. 1948) (transferred from Southern District, New York, to Southern District, Iowa, Central Division, where cause of action arose); Scott v. New York Cent. R. R., 8I F. Supp. 815 (N. D. Ill. 1948) (transferred from Northern District, Illinois, Eastern Division, to Southern District, West Virginia, or Southern District, Ohio, Eastern Division, with plaintiff to make choice; cause of action arose in Institute, Virginia; some of witnesses resided in Ohio, others in West Virginia); Conley v. Pennsylvania R. R., 87 F. Supp. 980 (S. D. N. X. 1950) (transferred from Southern District, New York, to Middle District, Pennsylvania, where cause of action arose); Maloney v. New York, N. H. \& H. R. R., 88 F. Supp. 568 (S. D. N. Y. I949) (transferred from Southern District, New York, to District of Massachusetts, where cause of action arose); Healy v. New York, N. H. \& H. R. R., 89 F. Supp. 614 (S. D. N. Y. I949) (transferred from Southern District, New York, to District of Connecticut where cause of action arose); Mazula v. Delaware $\&$ H. R. R., 90 F. Supp. 966 (S. D. N. Y. 1950) (transferred from Southern District, Ncw York, to Northern District, New York, where cause of action arose).

${ }^{208}$ Cullinan v. New York Central R. R., 83 F. Supp. 870 (S. D. N. Y. I948) (transfer denicd from Southern District, New York to Western District, New York, because defendant not strongly inconvenienced); Naughton v. Pennsylvania R. R., 85 F. Supp. 76I (E. D. Pa. 1949) (transfer of ten cases denied, nine from Eastern District, Pennsylvania, to Western District, Pennsylvania, and one from Eastern District, Pennsylvania, to Middle District, Pennsylvania, because showing insufficient to justify interference with plaintiff's choice of forum); Belair v. New York, N. H. \& H. R. R., 88 F. Supp. 572 (S. D. N. Y. 1950) (transfer denied from Southern District, New York, to District of Rhode Island; some of witnesses were in New York, others in Rhode Island or nearby, and balance of convenience not strongly in favor of defendant); Nagle v. Pennsylvania R. R., 89 F. Supp. 822 (N. D. Ohio 1950) (transfer denied from Northern District Ohio, Eastern Division, to Western District, Pennsylvania; bccause motion for transfer not presented until shortly before time trial was expected to begin); Skultety v. Pennsylvania R. R., 9I F. Supp. IIg (S. D. N. Y. I950) (transfer denied from Southern District, New York, to Western District, Pennsylvania, based on fact that motion was not filed until ten months after filing of suit and further fact that defendant's supporting affidavit did not specify how many witnesses would be called to testify).

${ }^{200} 330$ U. S. $50 x$ (1947). Justice Jackson had remarked in the majority opinion in that case (p. 505): 'It is true that in cases under the Federal Employers' Liability Act we have held that plaintiff's 
to the effect that plaintiff's choice of the forum could not under the Kepner and Miles cases be defeated on the basis of forum non conveniens quite naturally added to doubts on the subject.

A case soon reached the Supreme Court squarely raising the question-Southern $R y . v$. Mayfield.210 Two cases were brought in the circuit court of St. Louis against employing foreign railroads by nonresident plaintiffs on causes of action arising outside of Missouri. In each case a motion to dismiss was filed on the ground of forum non conveniens. The state courts denied relief as beyond the jurisdiction of the court to grant. There was some doubt from a reading of the opinion of the Supreme Court of Missouri whether its denial of relief was based on state or federal grounds. The Supreme Court of the United States reversed the decision holding that if the decision below had been based on the venue clause of the Act as interpreted in the Kepner and Miles cases, it was erroneous. The Missouri court, it said, should decide the question whether it had the right to apply the doctrine of forum non conveniens solely from the standpoint of the law of the state, since nothing in the federal law stood in the way. ${ }^{211}$ Justice Jackson, concurring, referred to his vote in the Miles case saying that it rested on what seemed to be compulsion of statutory provisions as to venue, since removed by Section I404(a) of the Judicial Code as interpreted in Ex parte Collett. ${ }^{212}$

When the case went back to the Supreme Court of Missouri it again held that relief was beyond the power of the lower court to grant, apparently on the ground

choice of a forum cannot be defeated on the basis of forum non conveniens. But this was because the special venue act under which those cases are brought was believed to require it. Baltimore \& Ohio R. R. v. Kepner, $3^{14}$ U. S. 44; Miles v. Illinois Central R. R., 315 U. S. 698 . Those decisions do not purport to modify the doctrine as to other cases governed by the general venue statutes."

310 340 U. S. I (I950).

212 After reviewing the Kepner and Miles cases, the Court (Frankfurter, J.) said (id. at 4-5): "But neither of these cases limited the power of a State to deny access to its courts to persons seeking recovery under the Federal Employers' Liability Act if in similar cases the State for reasons of local policy denies resort to its courts and enforces its policy impartially, see McKnett v. St. Louis \& S. F. R. Co., 292 U. S. $23^{\circ}$, so as not to involve a discrimination against Employers' Liability Act suits and not to offend against the Privileges-and-Immunities Clause of the Constitution. No such restriction is imposed upon the States merely because the Employers' Liability Act empowers their courts to entertain suits arising under it. There was nothing in that Act even prior to Sec. 1404(a) of the r948 revision of the Judicial Code, Title 28 , U. S. C., which purported 'to force a duty' upon the State courts to entertain or retain Federal Employers' Liability litigation 'against an otherwise valid excuse.' Douglas v. New York, N. H. \& H. R. Co., supra, 279 U. S. 377 , at $388 . "$

${ }_{212}$ Justice Jackson's concurrence reads as follows (id. at 5-6): "The Missouri Court appears to have acted under the supposed compulsion of Miles v. Illinois Central R. Co., 3I5 U. S. 698, among other of this Court's decisions. The deciding vote in that case rested, in turn, only on what seemed to be compulsion of statutory provisions as to venue. By amendment, $28 \mathrm{U}$. S. C. Sec. $14^{\circ} 4(\mathrm{a})$, as interpreted in Ex parte Collett, 337 U. S. 55, Congress has removed the compulsion which determined the Miles case, and the Missouri Court should no longer regard it as controlling. A federal court in Missouri would now be free to decline to hear this case and could transfer it to its proper forum. Certainly a State is under no obligation to provide a court for two nonresident parties to litigate a foreign-born cause of action when the Federal Government, which creates the cause of action, frees its own courts within that State from mandatory consideration of the same case. Because of what I wrote in the Miles case I add this note, but otherwise concur in the decision and opinion of the Court." 
that the doctrine of forum non conveniens is not recognized under the law of Missouri. ${ }^{213}$

It is too early yet to know what the state courts generally will do in recognizing the doctrine of forum non conveniens in FELA cases. In some jurisdictions the doctrine is being applied in trial courts. But there are few decisions from courts of last resort. One exception is the already noted refusal of Missouri to recognize the doctrine. Alabama is in the same category, a statute requiring its courts to entertain foreign suits being regarded as excluding the application of the doctrine. ${ }^{214}$ Another is its recognition in Utah in Mooney v. Denver \& R. G.W. $R . R^{215}$ An employee was injured in Colorado, where he and the witnesses lived. He brought suit in a state court in Utah. The defendant moved to dismiss on the ground of forum non conveniens. The court after an exhaustive review of the authorities, held that the motion was properly entertained, but ordered a further hearing to determine whether the facts warranted dismissal. ${ }^{210}$

There is no reason why state courts that apply the doctrine to other situations ${ }^{217}$ should not apply it in cases arising under the FELA in view of the clear pronouncement of the Supreme Court in Southern Ry. v. Mayfield.218

The question still remains whether the only avenue of relief is the application of the doctrine of forum non conveniens in the court of the forum by transfer under Section 1404(a) of the Judicial Code if the forum is federal, or by dismissal if the forum is state. Has the bar to an injunction on the ground of burden on interstate commerce or on the ground of oppression and hardship been removed by the enactment of Section I404(a) and the decisions in the Collett and Mayfield cases? Both of these grounds of relief, as already noted, are founded in considerations of convenience. Although there is a difference in remedy-in the form or mechanics by which relief is obtainable-they rest upon the same substantive principle as the doctrine of forum non conveniens. In the Kepner and Miles cases it was held that these principles of convenience could not prevail against the venue clause of the FELA. The authors of the Judicial Code of 1948, expressly avowing the need of overruling the Kepner case, proposed Section 1404 (a) to reassert the doctrine of forum non conveniens. Did not Congress in following this recommendation by

${ }^{213}$ State v. Mayfield, 362 Mo. 10I, 240 S. W. 2d 106 (195I). Bccause they thought from language appearing in its opinion that the Missouri court was still influenced by the compulsion of federal law, the railroads sought further review in the Supreme Court of the United States, but cortiorari was denied. 342 U. S. $87^{\prime \prime}$ (195I).

214 Ex parte State, 254 Ala. 10, 47 So. 2d 249 (1950).

218221 P. 2d 628 (Utah, 1950).

210 New York has long invoked forum non conveniens in FELA cases. Murnan v. Wabash Ry. 246 N. Y. 244,158 N. E. 508, 54 A. L. R. 1522 (1927); Douglas v. New York N. H. \& H. R. R., 279 U. S. 377 (1929).

${ }^{217}$ For example, the doctrine is recognized generally in some states: Whitncy v. Madden 400 Ill. I85, 79 N. E. 2d 593 (1948); Van Denburgh v. Tungsten Reef Mines Co., 48 Ariz. 54063 P. 2 d 647 (1936); Universal Adjustment Corp. v. Midland Bank Ltd., 281 Mass. 303, 184 N. E. 152 (1933).

${ }_{218} 340$ U. S. I (1950); See notes, 46 ILL. L. REv. II5 (I95I); 49 Mich. L. Rev. I06I (195I); 35 MinN. L. Rev. 596 (I95I); 16 Mo. L. Rev. I74 (I95I); 26 N. Y. U. L. Rev. 214 (195I); 30 N. C. L. REv. I68 (1952). 
enacting Section I404(a) reestablish a public policy in favor of the principle of forum non conveniens in all its forms?

The Kepner case, which the authors of the new code expressly sought to overturn, did not involve action by the court of the forum in dismissing or transferring a suit brought at an inconvenient place. Instead, it invoked a different form of remedy -an attempt to enjoin at the place of residence of plaintiff on the grounds of harassment and burden on interstate commerce a suit brought by him in a distant forum. Congress, dissatisfied with the decision denying relief, responded by enacting the fundamental principle that had been rejected in the Kepner case. The denial of the principle of forum non conveniens had its roots not in the express language of the venue clause of the FELA but in the subsequent judicial gloss upon that language. The judicial gloss had been swept away by the passage of Section I404(a) as the Court expressly held in the Collett case. ${ }^{219}$ One would have supposed therefore that, the inhibiting judicial gloss having been removed by a clear declaration of congressional policy, the right to relief from abuses of venue under the FELA under the previously well established grounds of burden on interstate commerce and of injunction against oppressive litigation would again be recognized. This expectation has not materialized.

In Atlantic Coast Line R. R. v. Wood ${ }^{220}$ it was held in Florida that a state court was powerless to restrain the prosecution of a FELA case in the courts of another state, and that neither Section I404(a) of the Judicial Code nor the decision in Ex parte Collett ${ }^{221}$ or Southern $R y . v$. Mayfield ${ }^{222}$ had changed the rule laid down by the Supreme Court of the United States in Miles v. Illinois Central $R . R^{223}$ The Court held that to sanction injunctive relief would resurrect an outmoded principle. ${ }^{224}$

The Supreme Court of Georgia reached the opposite conclusion in Atlantic Coast Line R. R. v. Pope. ${ }^{225}$ There the right of a state court in Georgia to restrain a resident of the state from prosecuting a FELA case in a state court of another jurisdiction was upheld. The railroad sought to restrain a Georgia resident from prosecuting an action in Alabama for injuries incurred in Georgia. It was held that the Georgia courts had the right to grant such an injunction on general equitable principles since the bar to the invocation of those principles by the decisions in the

210337 U. S. 55,6 I (I949).

23058 So. 2 d 549 (Fla. $\times 952)$.

221337 U. S. 55 (1949).

223340 U. S. I (I950).

233315 U. S. 698 (1942).

224 "We agree with counsel for appellant that prior to the Kepner and Miles cases a state court was authorized to enjoin the prosecution and maintenance in a sister state by a citizen of whom it had jurisdiction, and under proper circumstances of a suit under the Federal Employers' Liability Act, but in the light of the decisions by our highest judicial tribunal, are constrained to disagree in the view that any such power has been restored and now exists by virtue of $\$ 1404$ (a) or any other statute or rule of law. The effort here is not only to resurrect and apply an outmoded principle but to deprive the courts of a sovereign sister state of the right under its own statute to entertain a suit rightfully begun and which it may or may not retain in its discretion. Furthermore, to so hold would, though indirectly, violate the rule of comity between the states." 58 So. $2 \mathrm{~d} 549,55 \mathrm{r}$.

${ }^{225} 209$ Georgia 187 , 7I S. E. 2d 243 (1952). 
Kepner and Miles cases had been removed by subsequent legislative action and judicial decision. The Supreme Court of the United States granted certiorari and reversed the decision of the state court. ${ }^{226}$

Chief Justice Vinson, who in the Collett case had said that the judicial gloss on the venue clause of the FELA had been removed by Section r404(a), held that Congress deliberately chose to leave the Court's decision in the Kepner case intact except for the transfer powers conferred upon federal courts by Section 1404(a), and since Congress had not in any way devitalized the decision in the Miles case but instead had chosen to let it stand, the gloss of those two cases, with the exception noted, was still controlling. ${ }^{227}$

The Kepner and Miles cases, the Chief Justice said, had forbidden resort to injunction to prevent abuses under the venue clause of the FELA, and Congress, in revising the Judicial Code, had not legislated with respect to this form of action. The Miles case forbidding a state court to enjoin a FELA action in a court in a sister state therefore still stood. The operation of Section I404(a) is to be confined to the type of action for which it provides-transfers of cases between federal courts. Congress, the Chief Justice concluded, had been asked to go further by passing the Jennings bill to restrict the scope of the venue clause of the FELA but refused to do so. ${ }^{228}$ But neither the wording of Section 6 nor anything in its legislative history, it may be observed, evinced any intention of precluding the exercise of the principle of forum non conveniens or the use of any of the established forms of remedy for abuses of venue, and Congress in enacting Section 1404(a) had established a federal policy in favor of forum non conveniens.

${ }^{226}$ Pope v. Atlantic Coast Line R. R., 53 Sup. Ct. 749, decided April 27, 1953. This decision was rendered after the manuscript of this article had been completed and was in the hands of the printers, but before proofs had been corrected.

227 "The reference to the Kepner case in the Reviser's Note in nowise conflicts with what we think is the plain meaning of the language of Sec. 1404 (a) itself. The Kepner case was simply cited as an apt example of an inequitable situation which could be cured by providing the federal courts with the power to transfer an action on grounds of forum non conveniens. The full text of the Reviser's Note makes it clear that it was the power of the federal court to transfer, and not the power of the state court to enjoin, which was the remedy envisioned for any injustice wrought by Section 6 in the Kepner case.

"Thus, with the exception of the transfer powers conferred upon the federal courts by Scc. 1404(a), Congress deliberately chose to leave this Court's decision in the Kepner case intact.

"Since the narrow question in this case is simply whether the Miles case is still controlling; since we find no legislation which has devitalized it in any way, and since we find affirmative evidence that Congress chose to let it stand, the judgment below must be Reversed." Id. at 752, 753 .

228 "Congress might have gone further; it might have vested state courts with the power asscrted here. In fact, the same Congress which enacted Section I I04(a) refused to enact a bill which would have amended Section 6 of the Federal Employers' Liability Act by limiting the employce's choice of venue to the place of his injury or to the place of his residence.

"This proposed amendment-the Jennings Bill-focused Congress' attention on the decisions of this Court in both the Miles and the Kepner cases. The broad question-involving many policy considerations-of whether venue should be more narrowly restricted, was reopened; cogent arguments-both pro and con-were restated. Proponents of the amendment asserted that, as a result of the Miles and Kepner decisions, injured employees were left free to abuse their venue rights under Section 6 and 'harass' their employers in distant forums without restriction. They insisted that these abuses be curtailed. These arguments prevailed in the House which passed the Jennings Bill, but the proposed amendment died in the Senate Judiciary Committee, and Section 6 of the Federal Employers' Liability Act was left just as this Court had construed it." Id. at 753 . 
The Chief Justice relied upon Section 6 of the FELA as establishing Pope's right to sue in Alabama. That Section, he said (p. 75I), "provides that the employee may bring his suit wherever the carrier 'shall be doing business,' and admittedly respondent does business in Jefferson County, Alabama." The language quoted, however, is from the passage in Section 6 prescribing venue in federal district courts, ${ }^{229}$ and has been held not to affect the venue of state courts which is left to the practice of the forum. ${ }^{230}$ The jurisdiction of the Alabama court to entertain a suit under the FELA while recognized in Section 6 really proceeds from the supremacy clause of the Federal Constitution and the Federal General Jurisdictional Act. ${ }^{231}$ But the jurisdiction of a state court of Alabama is neither fixed nor protected from interference by the provisions of Section 6 regulating venue in federal courts.

Justice Frankfurter, the lone dissenter in the Pope case, was of the opinion that Congress in enacting Section $1404(\mathrm{a})$ had cut the ground from under the Kepner and Miles decisions by removing the judicial gloss represented by the Court's opinions in those two cases. In his view Section r404(a) was designed to express a policy with respect to the enforcement of the FELA-a policy contrary to that represented by the Kepner and Miles cases. ${ }^{232}$

$\mathrm{He}$ also called attention to the hostile spirit in which the Court addressed itself to the 1948 amendment to the Judicial Code, construing narrowly the effort to change by statute the law as laid down in judicial decisions. The Court, it may

220 "Under this chapter an action may be brought in a district court of the United States, in the district of the residence of the defendant, or in which the cause of action arose, or in which the defendant shall be doing business at the time of commencing such action." (Italies supplied.) 45 U. S. C. 56.

${ }^{230}$ Miles v. Illinois Cent. R. R., 315 U. S. 698, 703 (I94I); Doll y. Chicago Great Western R. R., I59 Minn. 323, I98 N. W. I006, 1007 (1924). See also Bainbridge v. Merchants \& Miners Co., 287 U. S. 278,280 (1932).

${ }_{231}$ Second Employers Liability Cases, 223 U. S. I, 56 (rgri). See also notes 13 and 17, supra.

233 "In Ex parte Collett, 337 U. S. 55, we held that 1404 (a) had removed the barrier of the Kepner and Miles decisions and made the doctrine of forum non conveniens applicable to cases arising in the federal courts under the Federal Employers' Liability Act as well as to the generality of cases. Congress, we said, naturally enough, had not repealed Sec. 6, which Kepner and Miles construed, but had removed the 'judicial gloss' represented by the Court's opinions in those two cases. 337 U. S. at $6 \mathrm{r}$.

"The Court now reaffirms this 'gloss' by treating it as an iron restriction not to be touched beyond the literal scope of its congressional rejection. In the Collett opinion the Court examined in detail the legislative materials pertaining to $\mathrm{Sec}, \mathrm{I}_{4} \mathrm{O}_{4}(\mathrm{a})$. It gave no intimation that Congress did any less than to remove the entire gloss of Kepner and Miles, thereby freeing us from the compulsions these two cases found in Sec. 6. Congress plainly indicated that the compulsions were the Court's artifact, not the purpose of Congress.

"The problem of avoiding abuse of the judicial process is not one that arises only in actions under the Federal Employers' Liability Act in the federal courts. Indeed, most of the actions under that Act are brought in the State courts. There is no rhyme or reason in assuming that Congress was eager to shut off abuses in the federal courts but forbade their prevention by State courts. (To suggest that Congress, if it saw fit, could 'vest' in State courts the power which this Court now denies them is, of course, to misconceive our problem. The issue is not what Congress might grant to State judiciaries but whether it had deprived them of a power which inheres in them.). Congress dealt specifically with the abuses in the federal courts since, in Title 28 , it was addressing itself to federal courts. But the central fact is that Congress was formulating a policy. To disregard the natural implications of a statute and to imprison our reading of it in the shell of the mere words is to commit the cardinal sin in statutory construction, blind literalness." 73 Sup. Ct. at 754-756. 
be recalled, had employed the opposite approach in construing Section 6 of the FELA. That Section, although containing a simple catalogue of the places where a suit under the FELA may be brought and thus constituting nothing more than a conventionally expressed rule of venue, was treated as destroying in FELA cases the right to resort to the well established equitable remedy for oppressive and unconscionable actions at law as well as destroying the right to relief from the same type of litigation on the ground of burden on interstate commerce. Thus Section 6 of the FELA was construed broadly while Section 1404(a) of the Judicial Code was construed narrowly.

\section{ConClusions}

The original venue under the FELA, governed as it was by the general federal venue statute requiring a suit against a corporation to be filed in a district in the state of incorporation of the defendant, was unsatisfactory to both plaintiffs and defendants. It resulted in inconvenience to both plaintiffs and defendants and it was thought to threaten special hardship to plaintiffs. The special venue clause inserted in Section 6 of the FELA by the amendment of Igro was avowedly designed to provide a liberalized venue to permit suit in a convenient forum. At the time of its passage there had been no abuses such as often occur under liberal venue laws and Congress exhibited no intention in enacting the clause to preclude resort to established methods of relief from abuses of venue. After a long series of conflicting decisions the courts read into this special venue clause a rigid rule of venue unjustified either by its express language or by its legislative history so as to cut off two of the three established forms of relief from abuse of venue. These decisions fostered wholesale solicitation of personal injury claims under the FELA with many attendant abuses. Section I404(a) of the Judicial Code as revised in I $94^{8}$ provided partial relief by allowing the transfer of cases from one federal district or division to another under the principle of forum non conveniens. In late years the right of the court of the forum in a state to dismiss a case brought therein on a claim imported from a distance has come to be recognized. The right to resort to the other two recognized forms of relief from abuse of venue is still denied, however, under the Kepner, Miles, and Pope cases, ${ }^{233}$ and it is unlikely that the solicitation of claims under the FELA by unethical lawyers can be satisfactorily curbed until further remedies are provided.

These remedies could take the form of $(x)$ amendment of Section 6 of the FELA so as to impose reasonable restrictions on venue, such as were contained in General Orders I8 and I8-A of the United States Railroad Administration in World War I or those put forward in the Jennings bill, ${ }^{234}$ or (2) an amendment of Section 6 of the FELA providing that nothing therein contained should be construed as interfering with the application of the principle of forum non conveniens in any

23s Baltimore \& Ohio R. R. v. Kepner, 314 U. S. 44 (194I); Miles v. Illinois Central R. R., 315 U. S. 698 (1942); Pope v. Atlantic Coast Line R. R., 73 Sup. Ct. 749 (1953).

${ }^{234}$ H. R. 1639, 80th Cong., Ist Sess. (1947). 
established form of action for relief from abuse of venue in any court, state or federal, or (3) the passage of statutes recognizing the doctrine of forum non conveniens in those states where the doctrine is not now recognized either at common law or by statute. In some states changes in constitutional provisions governing the details of jurisdiction and venue may be required. Perhaps a combination of these methods of approach would assist in reaching the goal. The enactment in the several states of modern statutes against barratry, champerty, and maintenance, and the enforcement of existing laws against the solicitation of personal injury cases by lawyers and laymen, would contribute to the same end, although past experience has shown that too much should not be expected from this avenue of approach. 
